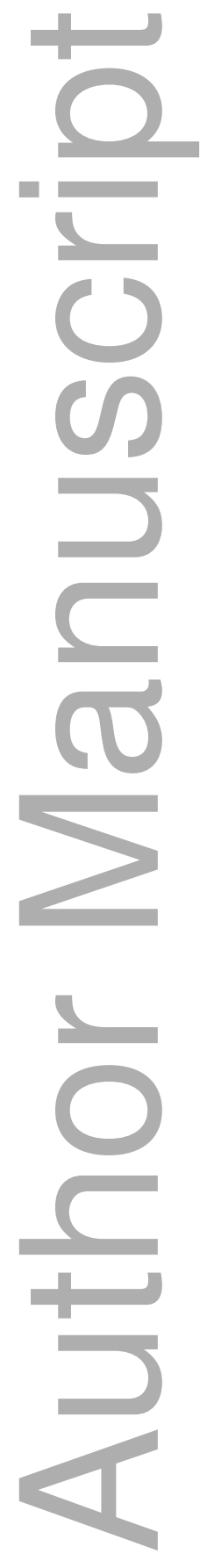

This is the author manuscript accepted for publication and has undergone full peer review but has not been through the copyediting, typesetting, pagination and proofreading process, which may lead to differences between this version and the Version of Record. Please cite this article as doi: 10.1111/jmg.12212

This article is protected by copyright. All rights reserved 


\section{High-grade metamorphism and partial melting of basic and intermediate rocks}

Richard M. Palin ${ }^{1 *}$, Richard W. White ${ }^{1}$, Eleanor C. R. Green², Johann F. A. Diener ${ }^{3}$, Roger Powell ${ }^{4}$, and Tim J. B. Holland ${ }^{5}$

${ }^{1}$ Institute of Geosciences, Johannes-Gutenberg University of Mainz, 55128 Mainz, Germany

${ }^{2}$ Institute of Geochemistry and Petrology, ETH Zurich, Clausiusstrasse 25, 8092 Zurich, Switzerland

${ }^{3}$ Department of Geological Sciences, University of Cape Town, Rondebosch 7701, South Africa

${ }^{4}$ School of Earth Sciences, University of Melbourne, Victoria 3010, Australia

${ }^{5}$ Department of Earth Sciences, University of Cambridge, Cambridge, CB2 3EQ, UK

*Corresponding author: richardmpalin@gmail.com

Short title: Partial melting of basic-intermediate rocks

\section{ABSTRACT}

Rocks of basic and intermediate bulk composition occur in orogenic terranes from all geological time periods and are thought to represent significant petrological components of the middle and lower continental crust. However, the former lack of appropriate thermodynamic models for silicate melt, amphibole, and clinopyroxene that can be applied to such lithologies at high temperature has inhibited effective phase equilibrium modelling of their petrological evolution during amphibolite- and granulite-facies metamorphism. In this work, we present phase diagrams calculated in the

$\mathrm{Na}_{2} \mathrm{O}-\mathrm{CaO}-\mathrm{K}_{2} \mathrm{O}-\mathrm{FeO}-\mathrm{MgO}-\mathrm{Al}_{2} \mathrm{O}_{3}-\mathrm{SiO}_{2}-\mathrm{H}_{2} \mathrm{O}-\mathrm{TiO}_{2}-\mathrm{O}_{2}$ (NCKFMASHTO) compositional system for a range of natural basic and intermediate bulk compositions for conditions of 2-12 kbar and $600-1050{ }^{\circ} \mathrm{C}$ using newly parameterised activity-composition relationships detailed in a companion paper in this issue (Green et al., 2016). Particular attention is given to mid-ocean ridge basalt (MORB) and diorite protolith bulk compositions. 
Calculated subsolidus mineral assemblages in all basic and intermediate rock types are modally dominated by hornblende and plagioclase, with variable proportions of epidote, clinopyroxene, garnet, biotite, muscovite, quartz, sphene, or ilmenite present at different pressures. The $\mathrm{H}_{2} \mathrm{O}$-saturated (wet) solidus has a negative $P-T$ slope and occurs between $\sim 620-690^{\circ} \mathrm{C}$ at mid- to lower-crustal pressures of 5-10 kbar. The lowest- $T$ melts generated close to the wet solidus are calculated to have granitic major-element oxide compositions. Melting at higher temperature is attributed primarily to multivariate hydrate-breakdown reactions involving biotite and/or hornblende. Partial melt compositions calculated at 800-1050 ${ }^{\circ} \mathrm{C}$ for MORB show good correlation with analysed compositions of experimental glasses produced via hydrate-breakdown melting of natural and synthetic basic protoliths, with Niggli norms indicating that they would crystallise to trondhjemite or tonalite.

Diorite is shown to be significantly more fertile than MORB and is calculated to produce high- $T$ melts $\left(>800^{\circ} \mathrm{C}\right)$ of granodioritic composition. Subsolidus and suprasolidus mineral assemblages show no significant variation between different members of the basalt family, although the $P-T$ conditions at which orthopyroxene stabilises, thus defining the prograde amphibolite granulite transition, is strongly dependent on bulk-rock oxidation state and water content. The petrological effects of open- and closed-system processes on the mineral assemblages produced during prograde metamorphism and preserved during retrograde metamorphism are also examined via a case-study analysis of a natural Archaean amphibolite from the Lewisian Complex, northwest Scotland.

Keywords: partial melting; basic; intermediate; lower continental crust; THERMOCALC

\section{INTRODUCTION}

During orogenesis, the continental crust reaches pressure $(P)$ and temperature $(T)$ conditions sufficient for partial melting to occur (England \& Thompson, 1986; Thompson \& Connolly, 1995). If produced in sufficient quantity, this melt can become mobile and ascend to higher structural levels, forming felsic igneous intrusions and leaving behind more basic, melt-depleted source rocks (e.g. Fyfe, 1970; Sawyer, 2001; White \& Powell, 2002; Brown, 
2007a; Diener et al., 2014). Unravelling the tectonothermal history of such partially melted rocks is a critical step towards understanding the formation of granulite-facies assemblages, migmatites, and the role that melting and melt loss have played in crustal differentiation through geological time (e.g. Vielzeuf et al., 1990; Johnson et al., 2012; Jiang et al., 2013).

Phase equilibria modelling represents a key methodology to investigate the petrological evolution of such deep-crustal rocks, given its ability to define equilibrium relationships between mineral and fluid/melt species at different $P-T$ conditions for a particular bulk-rock composition $(X)$. Indeed, previous studies have used this technique in order to make detailed examination of the petrological and rheological effects of adding/re-integrating (White et al., 2004; Indares et al., 2008; Guilmette et al., 2011; Korhonen et al,, 2013; Palin et al., 2013a) or extracting (White \& Powell, 2002; Diener \& Fagereng, 2014; Yakymchuk \& Brown, 2014) partial melt from its source during metamorphism. However, this modelling approach is limited to rocks for which appropriate thermodynamic descriptions of the constituent phases exist. The lower parts of the continental crust are known to contain a significant basic component, as determined indirectly via geophysical techniques (e.g. Christensen \& Mooney, 1995; Zandt \& Ammon, 1995), and by direct analysis of exhumed xenoliths (e.g. Rudnick \& Taylor, 1987; Downes, 1993; Condie, 1999) and deep-crustal granulite terranes (e.g. Harley, 1988; Johnson \& White, 2011), which produce melts of broadly tonalitic composition during anatexis (Spear, 1981; Spulber \& Rutherford, 1983; Wolf \& Wyllie, 1994; Rushmer, 1991; Zierenberg et al., 2012). Improvements have been made in recent years to activity-composition $(a-x)$ relations relevant to phases common in metabasites (Dale et al., 2005; Green et al., 2007; Diener et al., 2007; Diener \& Powell, 2012); however, the currently available metapelite melt model (Holland \& Powell, 2001; White et al., 2001, 2007, 2014a) is calibrated for use with silica-saturated peraluminous bulk compositions, thus is generally only suitable for investigating anatexis in pelitic and hornblende-absent quartzo-feldspathic lithologies. Furthermore, $a-x$ relations for several key ferromagnesian phases such as clinopyroxene (Green et al., 2007) and amphibole (Diener et al., 2007; Diener \& Powell, 2012) were largely calibrated for use at subsolidus conditions and so are unlikely to be applicable to high- $T$ calculations with any great veracity. 
In a companion paper in this issue, Green et al. (2016) present a set of $a-x$ relations for minerals and broadly tonalitic melt that have been developed explicitly for use in phase equilibria modelling of basic and intermediate rocks. In this contribution, we use these $a-x$ relations to investigate the petrological effects of high-grade metamorphism and partial melting in a range of natural bulk compositions, comprising mid-ocean ridge basalt (MORB), tholeiitic ocean island basalt (OIB), calc-alkaline basalt, diorite, and Archaean amphibolite. The calculated phase diagrams presented herein effectively reproduce commonly reported experimental and natural subsolidus and suprasolidus assemblages, predicting the generation of partial melt that is largely tonalitic, trondhjemitic, granodioritic, and granitic in composition. The importance of melt loss on the equilibrium mineral assemblages produced during prograde metamorphism and preserved during cooling and crystallisation is also discussed.

\section{PHASE EQUILIBRIUM MODELLING}

All phase equilibria modelling was performed in the 10-component NCKFMASHTO $\left(\mathrm{Na}_{2} \mathrm{O}-\mathrm{CaO}-\mathrm{K}_{2} \mathrm{O}-\mathrm{FeO}-\mathrm{MgO}-\mathrm{Al}_{2} \mathrm{O}_{3}-\mathrm{SiO}_{2}-\mathrm{H}_{2} \mathrm{O}-\mathrm{TiO}_{2}-\mathrm{O}_{2}\right)$ compositional system using THERMOCALC version 3.40i (Powell \& Holland, 1988), the internally consistent thermodynamic dataset of Holland \& Powell (2011; update ds62, 6 February, 2012), and the following $a-x$ relations: metabasite melt, augite, and hornblende (Green et al., 2016); garnet, orthopyroxene, biotite, and chlorite (White et al., 2014a); olivine and epidote (Holland \& Powell, 2011); magnetite-spinel (White et al., 2002); ilmenite-hematite (White et al., 2000); Cī plagioclase and K-feldspar (Holland \& Powell, 2003); and muscovite-paragonite from White et al. (2014b). Pure phases included quartz, rutile, sphene, and aqueous fluid $\left(\mathrm{H}_{2} \mathrm{O}\right)$. In the $a-x$ relations for muscovite-paragonite, the Gibbs energy function of the margarite end-member, $G_{\mathrm{ma}}(P, T)$, was modified by adding $\Delta G_{\mathrm{ma}}^{\mathrm{mod}}$ $=5.0 \mathrm{~kJ} / \mathrm{mol}$ relative to its value in the ds62 dataset, rather than $\Delta G_{\mathrm{ma}}^{\mathrm{mod}}=6.5 \mathrm{~kJ} / \mathrm{mol}$ as in White et al. (2014a). In both cases the modifications to $G_{\mathrm{ma}}(P, T)$ were imposed to prevent calculated overstability of margarite in metapelitic rocks, at low- $T$ and medium- to high- $P$ subsolidus conditions; there is no significant effect on the suprasolidus phase 
relations presented herein. The $a-x$ relations for hornblende used herein differ slightly from those published in Green et al. (2016), in that they omit a modification of $\Delta G_{\mathrm{gl}}^{\mathrm{mod}}=-3.0$ $\mathrm{kJ} / \mathrm{mol}$, added to the dataset Gibbs energy function of the glaucophane end-member, $G_{\mathrm{gl}}(P, T)$. This modification was applied after the preparation of this paper, to allow more appropriate predictions of blueschist-facies assemblages, but in our suprasolidus calculations the position of phase boundaries is affected by $\leq 10{ }^{\circ} \mathrm{C}$. Phase abbreviations are as follows: metabasite melt (L), hornblende (hb), augite (aug), orthopyroxene (opx), garnet (g), olivine (ol), epidote (ep), biotite (bi), chlorite (chl), magnetite (mt), ilmenite (ilm), hematite (hem), plagioclase (pl), K-feldspar (ksp), muscovite (mu), quartz (q), rutile (ru), sphene (sph), and aqueous fluid $\left(\mathrm{H}_{2} \mathrm{O}\right)$.

Phase diagram calculations employed representative bulk-rock compositions for MORB from Sun \& McDonough (1989), ocean island basalt from Macdonald (1968), calc-alkaline basalt from Nockolds \& Le Bas (1977), diorite from Pitcher et al. (1985), and Archaean amphibolite from Park (1966). Except where $\mathrm{H}_{2} \mathrm{O}$ is considered as a compositional variable, the modelled bulk-rock water contents were adjusted so that minimal free fluid $(\sim 1 \mathrm{~mol} . \%)$ was present at the 8-kbar solidus. Although this value may exceed that present in some high-grade metamorphic rocks at the onset of partial melting, this modelled water content was necessary to ensure that the solidus remained fluid-saturated over the entire $P-T$ range of interest. Where individual $\mathrm{FeO}$ and $\mathrm{Fe}_{2} \mathrm{O}_{3}$ contents were not originally reported for the lithologies modelled herein, bulk-rock $X_{\mathrm{Fe}^{3+}}=\mathrm{Fe}^{3+} /\left(\mathrm{Fe}^{2+}+\mathrm{Fe}^{3+}\right)$ ratios were fixed at low values (0.12-0.15, cf. Rebay et al., 2010) in keeping with the observation that unaltered basic igneous rocks generally have a low oxidation state (Schilling et al., 1983; Mallmann \& O’Neill, 2009). All bulk compositions used for phase diagram construction are given in Table 1.

Various sources of uncertainty can affect the accuracy and precision of calculated phase equilibria. The absolute positions of assemblage field boundaries in $P-T$ space - a function of factors such as the inadequacy of thermodynamic data or $a-x$ model descriptions of solid solution behaviour - are likely to be uncertain on the order of $\pm 50{ }^{\circ} \mathrm{C}$ and $\pm 1 \mathrm{kbar}$ for strongly temperature- and pressure-sensitive boundaries, respectively (Powell \& Holland, 
2008; Palin et al., 2016). However, displacements of important field boundaries are likely correlated such that the $a-x$ relations used herein should consistently produce the correct sequence of up- $T$ or up- $P$ assemblages (Green et al., 2016). Although phase proportions calculated with THERMOCALC are output as molar percent, they are normalised on a one-cation-basis, thus providing a very close approximation to volume percent.

\section{Calculated $P-T$ phase relations}

A $P-T$ pseudosection calculated for the MORB bulk composition of Sun \& McDonough (1989) is shown in Fig. 1, with contours showing the modal proportion of melt indicated by numbered, thin dashed lines. The fluid-saturated solidus (bold line) has a negative slope in $P-T$ space, occurring between $\sim 730{ }^{\circ} \mathrm{C}$ at $2 \mathrm{kbar}$ and $\sim 610^{\circ} \mathrm{C}$ at $12 \mathrm{kbar}$. Calculated subsolidus assemblages (hornblende-plagioclase-sphene- $\mathrm{H}_{2} \mathrm{O} \pm$ epidote, augite, biotite, muscovite, quartz, and/or ilmenite) correlate well with observations that mineral assemblages in subsolidus amphibolite-facies metabasites are commonly dominated by hornblende + plagioclase $( \pm$ minor quartz), with or without epidote, clinopyroxene, biotite, or garnet (e.g. Spear, 1993; Pattison, 2003). In comparison to the wet solidus in typical metapelitic assemblages (White et al., 2014a), the calculated metabasic solidus has a more pronounced negative slope and thus lies at higher- $T$ conditions at low pressure, but at lower- $T$ conditions at high pressure. Hornblende is calculated to be stable over almost the entire considered $P-T$ range, only being exhausted at low- $P-$ high- $T$ conditions below $\sim 5.5$ kbar and above $\sim 990^{\circ} \mathrm{C}$ (Fig. 1). With increasing temperature, the $\mathrm{Mg} /(\mathrm{Mg}+\mathrm{Fe}), \mathrm{Al}$, and Ti cation contents in hornblende increase, and the $\mathrm{Si}$ and $\mathrm{K}$ cation contents decrease, consistent with the studies of Binns (1965) and Phillips (1980). Garnet-bearing assemblages are stable at pressures greater than $\sim 9.5 \mathrm{kbar}$, but do not occur at subsolidus conditions within the $P-T-M_{\mathrm{H}_{2} \mathrm{O}}$ limits of interest. Epidote is restricted to pressures above $\sim 8$ kbar at low- $T$ conditions, and orthopyroxene occurs above $\sim 800{ }^{\circ} \mathrm{C}$, but below $\sim 10.5$ kbar. Augite is not calculated to be stable at low- $P-$ low- $T$ conditions below $\sim 5 \mathrm{kbar}$ and $\sim 725^{\circ} \mathrm{C}$, but is otherwise ubiquitous. We note that the augite model is one of two sets of $a-x$ relations for clinopyroxene presented in Green et al. (2016), the other being designated 
the omphacite model. The augite model is the appropriate choice for calcic clinopyroxene at high- $T$ in rocks lacking sodic pyroxene.

The narrow assemblage field L-hb-opx-aug-pl-ilm-q located between $~ 5.5-9.5 \mathrm{kbar}$ and $\sim 810-900{ }^{\circ} \mathrm{C}$ represents the first prograde appearance of orthopyroxene, and hence defines the boundary between the upper amphibolite and granulite facies at low/medium pressures. At temperatures higher than this field, the assemblages become quartz-absent. At pressures above $\sim 9.5$ kbar the appearance of garnet coincides with the loss of orthopyroxene with increasing pressure, leading to orthopyroxene-free, garnet-clinopyroxene-hornblende-bearing rocks typical of the high-pressure granulite field (e.g. O’Brien \& Rötzler, 2003; Pattison et al., 2003; Brown, 2007b). Contours marking the modal proportion of melt become more closely spaced with increasing temperature as hornblende is progressively consumed and the $\mathrm{H}_{2} \mathrm{O}$ content of the melt decreases. Assuming closed-system conditions, approximately 45-50\% partial melt is calculated to have been generated following the complete consumption of hornblende at low- $P$-high- $T$ conditions (Fig. 1). In general, melt proportion contours are characterised by a steep positive $\mathrm{d} P / \mathrm{d} T$, though they can become negative at high pressures where garnet is present.

A $P-T$ pseudosection for the diorite bulk composition of Pitcher et al. (1985) showing equilibrium phase relations and contours for the calculated abundance of melt is given in Fig. 2, where a number of similarities and differences can be seen compared to those calculated for MORB (Fig. 1). Subsolidus conditions are characterised by the assemblages hornblende plagioclase-biotite-quartz \pm epidote, garnet, muscovite, quartz, ilmenite, sphene, $\mathrm{H}_{2} \mathrm{O}$. Epidote-amphibolite-facies assemblages occur above 6 kbar and below $\sim 700$ ${ }^{\circ} \mathrm{C}$, and garnet becomes stable with increasing pressure above $\sim 8.5 \mathrm{kbar}$ (Fig. 2). These calculated equilibria support field observations of metadiorites and related metaigneous rocks of intermediate bulk composition that indicate common subsolidus assemblages dominated by plagioclase, quartz, biotite, and hornblende, with or without minor K-feldspar, epidote, sphene, magnetite, and garnet (e.g. Blattner, 1976; Mason \& Brewer, 2005; Moyen \& Martin, 2012; Vernon et al., 2012; Palin et al., 2013b; Weller et al., 2015).

As with the MORB composition, little melt is produced at the wet solidus and at 
temperatures less than $750{ }^{\circ} \mathrm{C}$. However, calculated suprasolidus equilibria show that biotite persists to significantly higher temperatures than in MORB $\left(\sim 800-850{ }^{\circ} \mathrm{C}\right.$, compared to $<730{ }^{\circ} \mathrm{C}$ ) and hornblende is exhausted at significantly lower temperatures $\left(\sim 810-900{ }^{\circ} \mathrm{C}\right.$, compared to $\left.>990{ }^{\circ} \mathrm{C}\right)$, thus increasing the $P-T$ stability field of hornblende-free "two-pyroxene" granulite at the expense of hornblende-bearing granulite (Fig. 2). The prograde appearance of orthopyroxene and augite in garnet-absent assemblages between $\sim 750-820{ }^{\circ} \mathrm{C}$ is coincident with significant melt production, with the calculated modal proportion increasing from $15 \%$ to $30-35 \%$ over a $20-30{ }^{\circ} \mathrm{C}$ interval at medium- $P$ conditions (Fig. 2). This zone of melt production largely results from the breakdown of biotite and quartz, which is followed by hornblende breakdown in the presence of quartz at higher grade. In contrast to MORB, quartz survives to higher temperatures than hornblende at $P>5$ kbar. The modelled diorite bulk composition is notably more fertile than MORB, with $\sim 80 \%$ partial melt predicted to have been generated at $1050{ }^{\circ} \mathrm{C}$ at low $P$, assuming all melt is retained in-situ in a closed-system environment.

Plots of the proportions of phases versus temperature in both the MORB and diorite compositions during prograde metamorphism at 5 and $10 \mathrm{kbar}$ ("modeboxes") are shown in Fig. 3. These diagrams are particularly useful in revealing relationships between the rate of melt production as a function of temperature $(\mathrm{d} L / \mathrm{d} T)$ and changes in equilibrium assemblages for each rock type. Although the subsolidus assemblages for diorite and MORB appear similar in terms of their constituents, the proportions of each phase are very different. Hornblende is considerably less abundant in subsolidus assemblages in diorite than in MORB, with modal proportions of $\sim 0.15-0.20$ and $\sim 0.65-0.70$, respectively. In MORB, a reduction in the modal proportion of subsolidus plagioclase with increasing pressure ( $\sim 0.25$ at $5 \mathrm{kbar}$ and $\sim 0.05$ at $10 \mathrm{kbar}$ ) coincides with an increase in the proportion of quartz $(\sim 0.05$ at 5 kbar and $\sim 0.10$ at $10 \mathrm{kbar})$ and additional epidote and augite (together $\sim 0.10$; Fig. $3 \mathrm{a}-\mathrm{b}$ ). A similar but smaller reduction in plagioclase modal proportion in the diorite bulk composition $(\sim 0.40$ at 5 kbar and $\sim 0.25$ at $10 \mathrm{kbar})$ is accommodated largely by more hornblende and additional muscovite and epidote (Fig. $3 \mathrm{c}-\mathrm{d})$. In the suprasolidus regime, the modal proportion of plagioclase in MORB at 5 and 10 kbar remains more-or-less constant (or decreases slightly) with increasing temperature, 
with the modal proportion of melt, augite, orthopyroxene, and garnet appearing to be controlled primarily by consumption of hornblende and quartz. Although the persistence of plagioclase during melt-producing reactions may be unintuitive, given that partial melts observed in metabasic rocks are mostly tonalitic, these calculated modal proportion changes for both feldspar and ferromagnesian minerals fit with those of experiments performed on basaltic greenstones (Beard \& Lofgren, 1991) and synthetic quartz-amphibolite (Patiño Douce \& Beard, 1995), where $\mathrm{CaO}$ and $\mathrm{Al}_{2} \mathrm{O}_{3}$ released during the breakdown of hornblende go towards enriching the anorthite content of solid plagioclase, and the $\mathrm{Na}_{2} \mathrm{O}$ component released enters the melt phase. Where the proportion of plagioclase does decrease up-temperature (in both experiments and in our model calculations), the remainder becomes distinctly anorthitic. Neither garnet nor orthopyroxene form in large quantities over this $P-T$ range, with a combined modal proportion of less than 0.10. By contrast, augite represents the major ferromagnesian solid phase at granulite-facies conditions, increasing in proportion up to $\sim 0.25$ at $1050{ }^{\circ} \mathrm{C}$. Breakdown of biotite immediately above the solidus is calculated to contribute to a small $(\sim 2-4$ mol.\%) increase in hornblende proportion in both MORB and diorite (Fig. 3), indicating that hornblende may also form as a peritectic mineral in natural rocks.

The rate of melt production at $5 \mathrm{kbar}$ in MORB is fairly constant, with an average $\mathrm{d} L / \mathrm{d} T$ of $\sim 1-2 \mathrm{~mol} . \%\left(10{ }^{\circ} \mathrm{C}\right)^{-1}$ throughout the entire suprasolidus regime (Fig. 3a). This rate is similar at higher- $P$ conditions, with the exception of a slight increase coincident with the production of garnet at $\sim 875-900{ }^{\circ} \mathrm{C}$ (Fig. 3b). However, the $\mathrm{d} L / \mathrm{d} T$ for the diorite bulk composition differs from MORB at both pressures. At $5 \mathrm{kbar}$, a pronounced melt-production step occurs at $\sim 800-840{ }^{\circ} \mathrm{C}$, coinciding with the complete consumption of biotite, hornblende, and quartz, and the production of peritectic orthopyroxene and augite (Fig. 3c). This temperature interval is characterised by a $\mathrm{d} L / \mathrm{d} T$ of $\sim 7 \mathrm{~mol} . \%\left(10{ }^{\circ} \mathrm{C}\right)^{-1}$ and sharp modal proportion changes in reactants and products; however, above and below this temperature interval, the average $\mathrm{d} L / \mathrm{d} T$ is $\sim 1-2 \mathrm{~mol} . \%\left(10^{\circ} \mathrm{C}\right)^{-1}$. At $10 \mathrm{kbar}$, there is no equivalent pronounced melting step, although the $\mathrm{d} L / \mathrm{d} T$ shows a continual increase in hornblende-bearing assemblages (from $\sim 1$ mol. $\%\left(10{ }^{\circ} \mathrm{C}\right.$ ) ${ }^{-1}$ at $650-775{ }^{\circ} \mathrm{C}$ to $\sim 2.2 \mathrm{~mol} . \%$ $\left(10^{\circ} \mathrm{C}\right)^{-1}$ at $\left.775-925^{\circ} \mathrm{C}\right)$, followed by a consistent $\mathrm{d} L / \mathrm{d} T$ of $\sim 2.5 \mathrm{~mol} . \%\left(10^{\circ} \mathrm{C}\right)^{-1}$ in 
hornblende-absent assemblages above $\sim 925^{\circ} \mathrm{C}$ (Fig. 3d).

\section{Compositional dependence of phase-assemblage stability}

As demonstrated by numerous studies, bulk-rock water content and oxidation state are two important compositional variables that affect phase-assemblage stability in metabasic rocks (Diener \& Powell, 2010; Rebay et al., 2010; Palin et al., 2014), although, either is generally unknown at any point during metamorphism, or constrained only within wide margins. In order to examine the dependence of the calculated assemblages in MORB to these compositional variables, a series of isobaric $T-M_{\mathrm{H}_{2} \mathrm{O}}$ and $T-M_{\mathrm{O}}$ pseudosections have been calculated (Figs 4 and 5, respectively). For the former, bulk molar $\mathrm{H}_{2} \mathrm{O}$ in mol.\% varies linearly along the $x$ axis. For the latter, bulk molar $\mathrm{O}$ in mol.\% varies linearly along the $x$ axis, with proportional changes in the ferrous-ferric conversion factor, $X_{\mathrm{Fe}^{3+}}=$ $\mathrm{Fe}^{3+} /\left(\mathrm{Fe}^{2+}+\mathrm{Fe}^{3+}\right)$. In terms of THERMOCALC's variables of bulk composition, $X_{\mathrm{Fe}^{3+}}$ is given by $2 \times \mathrm{O} / \mathrm{FeO}^{\text {tot }}$, where $\mathrm{FeO}^{\text {tot }}$ is bulk molar iron expressed as $\mathrm{FeO}$; bulk molar $\mathrm{O}$, $M_{\mathrm{O}}$, may range from 0 mol.\% (all iron as $\mathrm{FeO} ; X_{\mathrm{Fe}^{3+}}=0$ ) to $\frac{1}{2} \times \mathrm{FeO}^{\text {tot }}$ (all iron as $\mathrm{Fe}_{2} \mathrm{O}_{3}$; $X_{\mathrm{Fe}^{3+}}=1$ ). In each diagram, the original bulk composition used in Fig. 1a is shown by a vertical dotted line, contours for the modal proportion of melt are shown by numbered, thin dashed lines, and the extents of biotite-bearing assemblages in summary diagrams are marked by stippled regions. End-member bulk compositions are given in Table 1.

Figures $4 \mathrm{a}$ and $4 \mathrm{~b}$ show the effect of varying the molar proportion of $\mathrm{H}_{2} \mathrm{O}$ in the MORB bulk composition at pressures of 5 kbar and $10 \mathrm{kbar}$, respectively. Due to the limited porosity of metamorphic rock in the middle- and deep-crust, high values of $M_{\mathrm{H}_{2} \mathrm{O}}$ would likely only occur in the natural environment due to fluid infiltration during melting. We extend our compositional axis up to these values in order that the potential effects may be examined, although we do not suggest that they commonly occur in any particular geodynamic setting. The position of the solidus is strongly dependent on $M_{\mathrm{H}_{2} \mathrm{O}}$ for fluid-absent conditions, with its temperature increasing to $\sim 950{ }^{\circ} \mathrm{C}(5 \mathrm{kbar})$ and $\sim 1010{ }^{\circ} \mathrm{C}$ (10 kbar) as the bulk composition becomes more anhydrous and the proportions of biotite and hornblende decrease. However, for the range of $\mathrm{H}_{2} \mathrm{O}$ contents used here, there are 
distinct sections of the fluid-undersaturated solidi at $\sim 800-830{ }^{\circ} \mathrm{C}$ at $5 \mathrm{kbar}$ (Fig. $4 \mathrm{a}$ ) and $\sim 850-900{ }^{\circ} \mathrm{C}$ at $10 \mathrm{kbar}$ (Fig. 4b) that reflect substantial hornblende breakdown over these temperature ranges. The solidus temperature is calculated to lie at significantly higher temperatures in quartz-absent assemblages, as documented from natural amphibolites by Hartel \& Pattison (1996). Contours for the modal proportion of partial melt mimic the shape of the solidi, such that the fertility of MORB at any given suprasolidus temperature is proportional to the bulk-rock $\mathrm{H}_{2} \mathrm{O}$ content. The prograde appearance of orthopyroxene in the suprasolidus regime is moderately dependent on the bulk-rock water content at both pressure conditions, becoming stable at progressively lower- $T$ with decreasing $M_{\mathrm{H}_{2} \mathrm{O}}$. In $\mathrm{H}_{2} \mathrm{O}$-undersaturated bulk compositions at $5 \mathrm{kbar}$, it becomes a stable subsolidus phase at $M_{\mathrm{H}_{2} \mathrm{O}}$ below $\sim 3.5 \mathrm{~mol} \%$, indicating that melt-absent hornblende- and biotite-bearing granulite could form at relatively low $P-T$ conditions in fluid-undersaturated compositions. At $10 \mathrm{kbar}$, subsolidus phase assemblages at equivalently low values of $M_{\mathrm{H}_{2} \mathrm{O}}$ would be characterised by garnet-bearing assemblages with or without biotite, thus being petrologically classified as garnet amphibolite or garnet granulite (Fig. 4b).

Figures $5 \mathrm{a}$ and $5 \mathrm{~b}$ show $T-M_{\mathrm{O}}$ pseudosections calculated at $5 \mathrm{kbar}$ and $10 \mathrm{kbar}$ spanning a range of bulk $\mathrm{O}$ values from 0 to 3.76 , covering the full range of $X_{\mathrm{Fe}^{3+}}$ from 0 to 1. The effect of increasing $M_{\mathrm{O}}$ in the MORB bulk composition is to reduce the solidus temperature by up to $80{ }^{\circ} \mathrm{C}$ at 5 kbar (Fig. 5a) and up to $20^{\circ} \mathrm{C}$ at $10 \mathrm{kbar}$ (Fig. 5a), to transition from ilmenite-bearing assemblages to hematite-bearing assemblages at $M_{\mathrm{O}} \sim$ 1.9-2.3, and to significantly reduce orthopyroxene stability by increasing the temperature of its first appearance during prograde metamorphism to $>1050{ }^{\circ} \mathrm{C}$ at $5 \mathrm{kbar}$ (Fig. 5a) and $\sim 1040{ }^{\circ} \mathrm{C}$ at $10 \mathrm{kbar}$ (Fig. 5b). Although these extreme temperatures for orthopyroxene stability are only achieved at the uppermost limit of bulk-rock $M_{\mathrm{O}}$, and so are not generally relevant for natural metabasites, merely doubling the modelled value of 0.45 to 0.90 at 5 kbar delays orthopyroxene appearance during prograde metamorphism from $\sim 800$ ${ }^{\circ} \mathrm{C}$ to $\sim 860{ }^{\circ} \mathrm{C}$, showing that the bulk-rock oxidation state imparts a non-trivial control on the amphibolite-granulite transition, even at relatively reduced conditions. At high- $P$ conditions, garnet is not stable at $M_{\mathrm{O}}>1.52$ and epidote-bearing suprasolidus assemblages become more common with increasing $M_{\mathrm{O}}$. At $10 \mathrm{kbar}$, the proportion of 
partial melt predicted to have formed at any given temperature is largely insensitive to varying $M_{\mathrm{O}}$, despite changes in the equilibrium assemblages discussed above. However, the apparent similar insensitivity of melt production to $M_{\mathrm{O}}$ at $5 \mathrm{kbar}$ may be an artifact of the modelling, as an increase in $M_{\mathrm{O}}$ results in a notable widening of the fields of coexisting melt and fluid, consistent with low- $P$ assemblages requiring less bulk $\mathrm{H}_{2} \mathrm{O}$ to saturate the assemblage at the wet solidus than at medium- or high- $P$.

Other members of the basalt family

Although we use MORB as a representative lithology with which to investigate the petrological evolution of metabasites during high- $T$ metamorphism, numerous workers have shown via geochemical criteria that mid-crustal basic granulites have also been derived from non-MOR basaltic compositions (Dougan, 1977; Montanini \& Tribuzio, 2001; Janoušek et al., 2006; Jöns \& Schenk, 2008). It is therefore important to examine the control that basic protolith type exerts on the salient calculated phase equilibria predicted under these conditions. Figure 6 shows a $T-X$ pseudosection calculated for $5 \mathrm{kbar}$ in which the $x$-axis is a composite of three linear compositional trends between four end-member bulk compositions. This diagram allows examination of the effect of the variation in basalt protolith type on equilibrium phase assemblages, which are also compared to those for diorite. These rock types are ordered along the $x$-axis so as to produce general compositional trends from left to right on the diagram, comprising an increase in bulk-rock $\mathrm{SiO}_{2}, \mathrm{Al}_{2} \mathrm{O}_{3}, \mathrm{~K}_{2} \mathrm{O}$, and $\mathrm{Na}_{2} \mathrm{O}$, and a decrease in $\mathrm{CaO}, \mathrm{MgO}, \mathrm{FeO}$, and $\mathrm{TiO}_{2}$.

An important feature of Fig. 6 is that the calculated equilibrium phase assemblages at any given temperature at 5 kbar show no significant variation between ocean island, mid-ocean ridge, and calc-alkaline basalt types. The solidus temperature remains in the narrow temperature range $690-695^{\circ} \mathrm{C}$ and the calculated modal proportions of melt at any given temperature are similar $( \pm 3-5$ mol.\%). Subsolidus conditions are represented by assemblages containing hornblende, biotite, plagioclase, sphene, quartz, and $\mathrm{H}_{2} \mathrm{O}$ with or without augite, ilmenite, and rutile. The temperatures at which orthopyroxene first stabilises and hornblende is exhausted during prograde metamorphism both occur over 
narrow $15-20{ }^{\circ} \mathrm{C}$ ranges in each basalt type, at $\sim 805-825{ }^{\circ} \mathrm{C}$ and $\sim 1025-1040{ }^{\circ} \mathrm{C}$, respectively. Most variation in calculated phase assemblages results from the changing stabilities of $\mathrm{Fe}-\mathrm{Ti}$ oxides, though these are only present in minor proportions $(<1-2$ $\operatorname{mol} \%$ ).

These similarities in phase assemblages and pseudosection topologies remain mostly consistent at higher and lower pressures. Figure 7 shows $P-T$ pseudosections calculated for the calc-alkaline (Fig. 7a) and ocean island (Fig. 7b) basalt bulk-rock compositions of Nockolds \& Le Bas (1977) and Macdonald (1968), respectively (Table 1). Akin to MORB, the wet solidi have negative $P-T$ slopes, reaching minimum temperatures of $\sim 620-640{ }^{\circ} \mathrm{C}$ at 9.5-10.5 kbar, and both compositions show a broadly linear pressure-independent $\mathrm{d} L / \mathrm{d} T$, with near-vertical and equally spaced melt proportion contours. Important assemblage field boundaries that define different petrological products across $P-T$ space are shown in Fig. 7c for all three basalt types. The prograde orthopyroxene-in assemblage-field boundaries that define the amphibolite-granulite transition in low- and medium- $P$ metabasic rocks are within $20{ }^{\circ} \mathrm{C}$ of each other and occur at similar pressures (9.5-10.5 kbar) in garnet-bearing assemblages. Hornblende is fully consumed in each basalt type within the same narrow temperature range, regardless of pressure. The stability of garnet at high- $P$ shows notable variation, occurring within the calc-alkaline bulk composition (Fig. 7a) at lower $P$ and $T$ than in the tholeiite for temperatures below $1000{ }^{\circ} \mathrm{C}$, though this is most likely a result of its higher $\mathrm{CaO}$ and $\mathrm{Al}_{2} \mathrm{O}_{3}$ contents. These calculations also show remarkable agreement with $P-T$ conditions reported by Spear (1981) for the prograde appearance of augite $\left(\sim 770-790{ }^{\circ} \mathrm{C}\right)$ and orthopyroxene $\left(\sim 800-820^{\circ} \mathrm{C}\right)$, and the sphene-ilmenite transition, as determined from experiments performed on olivine tholeiite.

Modebox diagrams calculated at $P=5$ kbar show that the only notable difference in calculated phase proportions between calc-alkaline (Fig. 7d) and ocean island basalt (Fig. 7e) bulk compositions is the hornblende:plagioclase ratio, which is higher in the former than the latter. Considered together, these features indicate that very similar phase assemblages would form during prograde metamorphism of either unaltered ocean island basalt, MORB, or calc-alkaline basalt at almost identical temperature conditions, 
progressing between subsolidus amphibolite, melt-bearing amphibolite, hornblende-bearing granulite, and hornblende-free granulite with increasing grade in the middle crust, albeit with small differences in mineral proportions. This insensitivity to variation in protolith major-element oxides likely reflects the relatively limited range of unaltered basalt compositions, though is in stark contrast to the control that bulk-rock $\mathrm{H}_{2} \mathrm{O}$-content and oxidation state exert (Figs 4 and 5).

\section{Melt compositions produced during prograde metamorphism}

Alongside examining the changing modal proportions of phases at different $P-T$ conditions, pseudosection-based forward modelling allows examination of the predicted changing compositions of partial melt generated during anatexis. The calculated melt compositions show moderate variation in major-element oxides as functions of protolith, pressure, and temperature, and are shown on modified total alkali-silica (TAS) diagrams (Fig. 8: Le Bas et al., 1986; Middlemost, 1994), and $\mathrm{CaO}-\mathrm{Na}_{2} \mathrm{O}-\mathrm{K}_{2} \mathrm{O}$ wt\% oxide (Fig. 9a) and normative anorthite-albite-orthoclase (An-Ab-Or) ternary diagrams (Fig. 9b) in order to provide a petrological framework for their interpretation. Representative compositions for MORB- and diorite-derived partial melts calculated at various temperatures along closed-system 5- and 10-kbar isobaric heating paths are given in Table 2, and are hereafter referred to in the text as M5, M10, D5, and D10.

The initial M5-M10-D5-D10 melts produced at each respective solidus have a restricted range in $\mathrm{Na}_{2} \mathrm{O}+\mathrm{K}_{2} \mathrm{O}$ and $\mathrm{SiO}_{2}$ contents (wt\% oxide, anhydrous normalised basis), plotting in the granite field on a TAS diagram at both pressures (Fig. 8). All four are rich in $\mathrm{H}_{2} \mathrm{O}$ (9.4-15.9 wt\% oxide) and FeO- and $\mathrm{MgO}$-poor, with generally less than 0.1 wt\% of either component (Table 2). With increasing temperature, the $\mathrm{SiO}_{2}$ content of each melt increases until quartz is lost from the coexisting solid assemblage, after which point the melt composition becomes increasingly less silicic (Table 2). The $\mathrm{Al}_{2} \mathrm{O}_{3}, \mathrm{CaO}, \mathrm{FeO}$, and $\mathrm{MgO}$ contents of each M5-M10-D5-D10 melt increase during isobaric heating, whereas the $\mathrm{H}_{2} \mathrm{O}$ content of each decreases (Table 2). The $\mathrm{K}_{2} \mathrm{O}$ content of MORB-derived melt generally decreases with increasing temperature, although it increases in 
diorite-derived melts until biotite (D5) or K-feldspar (D10) are completely consumed from the coexisting solid assemblage (Fig. 3), after which it diminishes. By contrast, the $\mathrm{Na}_{2} \mathrm{O}$ content of D5 and D10 decreases during heating where hornblende is stable and increases where hornblende has been exhausted (Fig. 3). In MORB-derived partial melts, there is no clear or consistent relationship between the coexisting solid phase assemblage and the $\mathrm{Na}_{2} \mathrm{O}$ content of the derived partial melt, which shows a general increase with temperature for M5 and a general decrease with temperature for M10 (Table 2). For each protolith, the $10 \mathrm{kbar}$ partial melt is more hydrous than that at $5 \mathrm{kbar}$ at any equivalent temperature (Table 2), consistent with the $\mathrm{H}_{2} \mathrm{O}$-solubility observations of Burnham (1979) and Silver \& Stolper (1989). For MORB-derived melts, the overall compositional changes described above are expressed as a progression through the granite, granodiorite, and diorite fields on a TAS diagram, with the highest- $T$ melt compositions having a $\mathrm{SiO}_{2}$ content of $\sim 54-55$ wt $\%$ at $1050^{\circ} \mathrm{C}$ (Fig. 8a; Table 2). Diorite-derived melts show a smaller compositional range, with both D5 and D10 melts at $1050{ }^{\circ} \mathrm{C}$ being significantly more silicic than MORB-derived equivalents ( 64 wt $\%$; Fig. $8 b)$.

Figure 9a shows calculated MORB- and diorite-derived melt compositions plotted in ternary $\mathrm{CaO}-\mathrm{Na}_{2} \mathrm{O}-\mathrm{K}_{2} \mathrm{O}$ wt\% oxide compositional space, alongside analysed glass compositions from experimental studies that have investigated hydrate-breakdown melting of basic source rocks (diamonds symbols). Data-source acronyms are defined in the figure caption. Glasses analysed during these experimental studies were generated at $P-T$ conditions of $1-12.5 \mathrm{kbar}$ and $800-1115{ }^{\circ} \mathrm{C}$ using either synthetic analogues or natural samples of basalt (typically MORB), greenstone, or amphibolite. Filled diamond symbols represent data from experiments conducted at 5-10 kbar, thus matching the pressures of our calculated compositions, whereas dashed diamonds represent data from outside of this range. Only data for pseudosection-derived melt compositions calculated at $800-1050{ }^{\circ} \mathrm{C}$ are shown, with those calculated below $800{ }^{\circ} \mathrm{C}$ indicated by dashed lines.

Despite the diversity of experimental conditions and source materials, calculated melt compositions for M5 and M10 correlate fairly well with these experimental results, which mostly lie within the normalised $\mathrm{CaO}-\mathrm{Na}_{2} \mathrm{O}-\mathrm{K}_{2} \mathrm{O}$ compositional range $\sim 15-70$ wt\% $\mathrm{CaO}$, 
20-60 wt\% $\mathrm{Na}_{2} \mathrm{O}$, and $\sim 0-35 \mathrm{wt} \% \mathrm{~K}_{2} \mathrm{O}$ (Fig. 9). Our calculated MORB-derived partial melts have a composition $\sim 25 \mathrm{wt} \% \mathrm{CaO}, \sim 50$ wt $\% \mathrm{Na}_{2} \mathrm{O}$, and $\sim 25 \mathrm{wt} \% \mathrm{~K}_{2} \mathrm{O}$ at $800{ }^{\circ} \mathrm{C}$, and become relatively $\mathrm{CaO}$-enriched and $\mathrm{K}_{2} \mathrm{O}$ - and $\mathrm{Na}_{2} \mathrm{O}$-depleted during heating, ultimately plotting at $\sim 50 \mathrm{wt} \% \mathrm{CaO}, \sim 45 \mathrm{wt} \% \mathrm{Na}_{2} \mathrm{O}$, and $\sim 5 \mathrm{wt} \% \mathrm{~K}_{2} \mathrm{O}$ at $1050{ }^{\circ} \mathrm{C}$ (Fig. 9). Although these $800-1050{ }^{\circ} \mathrm{C}$ calculated compositions have similar $\mathrm{K}_{2} \mathrm{O}$ contents to the main cluster of experimental data, they have relatively lower $\mathrm{CaO}: \mathrm{Na}_{2} \mathrm{O}$ ratios, which may be taken to suggest that $\mathrm{Na}$ is more compatible in our phase equilibria calculations than is suggested by experiments, although numerous and diverse sources of uncertainty in both methods can contribute to such differences (White et al., 2011). Not only is Na-loss a common problem during electron microprobe analysis of silicate glasses (Nielsen \& Sigurdsson, 1981), which implies that many of these experimentally determined data points may lie closer to the $\mathrm{Na}_{2} \mathrm{O}$ corner than are represented here, but several studies have also noted positive correlations between the $\mathrm{K}_{2} \mathrm{O}: \mathrm{Na}_{2} \mathrm{O}$ ratio (Beard \& Lofgren, 1991) and the CaO: $\mathrm{Na}_{2} \mathrm{O}$ ratio (Rapp et al., 1991; Wolf \& Wyllie, 1994; Springer \& Seck, 1997) of starting materials and their derivative melts (cf. Moyen, 2011).

An alternative method of interpreting the petrological products of our modelling involves normative geochemistry, whereby the estimated proportions of solid phases that would form during crystallisation of these M5-M10-D5-D10 melts are determined using Niggli norms (Niggli, 1936). The results of such calculations are shown in Fig. 9b on an An-Ab-Or ternary diagram, where it can be seen that all melts generated at their solidi lie within the trondhjemite (M10) or granite field (M5-D5-D10). Higher-temperature MORB-derived melts migrate through the trondhjemite or granite fields, and ultimately enter the tonalite field at $\sim 810^{\circ} \mathrm{C}$ for M10 and $\sim 990{ }^{\circ} \mathrm{C}$ for M5 (Fig. 9b). These data show good correlation with those of natural trondhjemite-tonalite-granodiorite plutons that commonly make up Archaean terranes, and which are thought to have been derived from partial melting of hydrated metabasalt (Moyen \& Martin, 2012). Diorite-derived melts trend further into the granite field during heating until biotite (D5) or K-feldspar (D10) are completely consumed from the coexisting solid assemblage (Fig. 3). After this point, the calculated melts become less $\mathrm{K}_{2} \mathrm{O}$-rich and are calculated to crystallise less orthoclase, thus becoming granodioritic. Notably, no trondhjemites or tonalites are 
calculated via normative geochemistry to form from this modelled diorite protolith, even at temperatures up to $1050^{\circ} \mathrm{C}$.

\section{The effects of melt loss during prograde and retrograde metamorphism}

The phase diagrams presented in Figs 1-6 are relevant to the prograde metamorphic evolution of each respective rock type assuming that all partial melt produced is retained in-situ, which at the highest- $T$ and lowest- $P$ conditions calculated constitutes a melt:residue ratio of up to 4:1. In such a closed-system environment the large melt proportions would form diatexite, and cooling and crystallisation of melt during retrograde metamorphism would likely lead to the destruction of granulite-facies mineral assemblages and the formation of amphibolite-facies assemblages upon crossing the solidus (Spear et al., 1999; White \& Powell, 2002). However, not only is the in-situ retention of such large proportions of melt generally unlikely from a rheological standpoint (Vigneresse et al., 1996; Renner et al., 2000; Sawyer, 2001), the occurrence of relatively fresh basic granulite at the surface of the Earth suggests that melt loss is a common process in granulite terranes and is also necessary for their preservation (e.g. Fyfe, 1970, 1973; Powell \& Downes, 1990; Brown, 2002; White \& Powell, 2002).

The effects of melt loss on the equilibrium assemblages developed during prograde and retrograde metamorphism are examined here with reference to a natural Archaean amphibolite from the Gairloch region of the southern Lewisian Complex, northwest Scotland. Gairloch metabasites are reported by Park (1966) to represent subsolidus amphibolite-facies metamorphic equivalents of olivine tholeiites and are dominated by hornblende, plagioclase, and quartz, with minor epidote, garnet, biotite, magnetite, ilmenite, and/or sphene. A $P-T$ pseudosection constructed for an average Gairloch amphibolite bulk composition (Table 1) is shown in Fig. 10a and acts as a reference for consideration of its petrological evolution in a closed-system environment. To model an open-system environment, we consider melt extraction to be a cyclical process, with melt loss occurring in pulses each time its modal proportion reaches a critical threshold (e.g. Yakymchuk \& Brown, 2014). We use a proportion of $7 \%$ to represent this threshold (cf. 
Rosenberg \& Handy, 2005) and assume that only 1\% of this melt is retained in-situ following the drainage event. Because melt extraction changes the bulk composition, a new adjusted composition must be used to calculate the equilibrium phase assemblages after each drainage event, resulting in a $P-T$ pseudosection that is a composite of numerous slices (Fig. 10b). Melt-extraction calculations utilised bulk compositions calculated at different temperatures at a nominal pressure of $7 \mathrm{kbar}$ on each $7 \mathrm{~mol} . \%$ contour. Bulk compositions used for construction of each slice on Fig. 10b are given in Table 3.

Figure 10a shows a very similar topology to that calculated for MORB (Fig. 1), supporting the aforementioned point that basalts of varying compositions are expected to follow similar mineral assemblage evolutions during crustal metamorphism (Fig. 6). During isobaric heating at $7 \mathrm{kbar}$, melt first forms at $\sim 660{ }^{\circ} \mathrm{C}$ at the wet solidus, with its proportion increasing largely at the expense of biotite and hornblende until it reaches the 7 mol.\% threshold at $728{ }^{\circ} \mathrm{C}$ in the assemblage field L-hb-aug-bi-pl-ilm-q (Fig. 10b). In a closed-system environment partial melting would continue with increasing temperature, with biotite being fully consumed at $\sim 800{ }^{\circ} \mathrm{C}$, followed by orthopyroxene at $\sim 1000{ }^{\circ} \mathrm{C}$, and hornblende at $\sim 1025{ }^{\circ} \mathrm{C}$. Just over $70 \mathrm{~mol} . \%$ partial melt is predicted to have formed at $1050{ }^{\circ} \mathrm{C}$, coexisting with augite, plagioclase, and ilmenite (Fig. 10a). Changes in the modal proportions of all phases during this closed-system evolution are shown on the upper modebox diagram in Fig. 10c.

In a more geologically realistic open-system environment, as soon as 7 mol.\% melt is accumulated at $728^{\circ} \mathrm{C}, 6 \mathrm{~mol} . \%$ of it is assumed to drain away and thus fractionate the total bulk-rock composition of the amphibolite. Successive melt accumulation and extraction events during heating cause the bulk composition of the melt-depleted residuum to become progressively richer in $\mathrm{Al}_{2} \mathrm{O}_{3}, \mathrm{CaO}, \mathrm{MgO}, \mathrm{TiO}_{2}$, and $\mathrm{Fe}_{2} \mathrm{O}_{3}$, and poorer in $\mathrm{H}_{2} \mathrm{O}$, $\mathrm{SiO}_{2}, \mathrm{~K}_{2} \mathrm{O}$, and $\mathrm{Na}_{2} \mathrm{O}$ (Table 3 ). The residuum bulk composition becomes progressively FeO-enriched during prograde metamorphism up to the fourth melt extraction event, but then becomes depleted in $\mathrm{FeO}$ with continued melt loss. Changes in the modal proportions of phases during this open-system evolution are shown on the lower modebox diagram in Fig. 10c. 
The overall topology of Fig. 10b (above the $P-T$ conditions representing the first melt-loss event) shows some notable differences to that calculated for the closed-system amphibolite (Fig. 10a). The stability field of garnet is expanded to lower- $P$, from $\sim 8.25$ kbar (closed system) to $\sim 7.5$ kbar (open system), orthopyroxene is stabilised up to $\sim 1040$ ${ }^{\circ} \mathrm{C}$ at 7 kbar following successive melt-extraction events instead of being consumed at $\sim 1000{ }^{\circ} \mathrm{C}$ in a closed-system environment, and the stability field of olivine increases up- $P$ from below 4 kbar (undrained) to $\sim 6.5 \mathrm{kbar}$ (drained). In addition, hornblende remains stable at $1050^{\circ} \mathrm{C}$ following successive melt loss events, instead of being consumed at $\sim 1025$ ${ }^{\circ} \mathrm{C}$ in a closed-system environment. It is clear, therefore, that the petrological evolution of such a basic precursor rock is dependent on the degree of melt loss that occurs during heating. If a rock of this composition underwent prograde metamorphism at low- $P$ conditions, it may contain the assemblage melt, hornblende, orthopyroxene, augite, plagioclase, and ilmenite in a closed-system environment (Fig. 10a), but could have additional olivine and magnetite in an open system environment (Fig. 10b). Even products of prograde isobaric heating at 7 kbar up to peak temperatures of $950-1000{ }^{\circ} \mathrm{C}$, which would be characterised in both the open- and closed-system environments by the same equilibrium assemblage of melt, hornblende, orthopyroxene, augite, plagioclase, and ilmenite (Figs 10a and 10b), would have significantly different proportions of solid phases (Fig. 10e). This demonstrates the importance of considering fractionation of bulk-rock compositions due to melt loss when using pseudosection modelling to constrain the peak metamorphic $P-T$ conditions reached by granulite-facies metabasites.

The retrograde metamorphic evolution will also depend strongly on the degree of melt loss experienced during its prograde evolution. At peak metamorphic conditions of $7 \mathrm{kbar}$ and $910^{\circ} \mathrm{C}$ in a closed-system environment, modelling predicts an assemblage of $35 \mathrm{~mol} . \%$ melt, 26 mol.\% hornblende, $18 \mathrm{~mol} . \%$ augite, $15 \mathrm{~mol} . \%$ plagioclase, $5 \mathrm{~mol} . \%$ orthopyroxene, and 1 mol.\% ilmenite (Figs 10a and 10c). During exhumation, orthopyroxene would be expected to be consumed at the expense of biotite whilst still at suprasolidus conditions, regardless of the exact retrograde $P-T$ path experienced, producing an amphibolite-facies assemblage upon crystallisation of the final melt fraction (e.g. 54-61 mol.\% hornblende, 21-29 mol.\% plagioclase, 7 mol.\% biotite, 1-3 mol.\% augite, 1-2 mol.\% sphene and/or 
ilmenite, and 1-2 mol.\% $\mathrm{H}_{2} \mathrm{O}$ between 5-7 kbar) that is petrologically similar to the protolith (Park, 1966). However, if a rock experienced progressive prograde melt loss, it would develop a significantly different assemblage during its retrograde evolution. Figure 10d shows a $P-T$ pseudosection constructed for this amphibolite composition after having reached $7 \mathrm{kbar}$ and $910{ }^{\circ} \mathrm{C}$ following four separate melt-extraction events (bulk composition 4 from Table 3). Although the peak assemblage would be identical to the undrained scenario, this rock would have more of the solid phases (39 mol.\% hornblende, 24 mol.\% augite, 24 mol.\% plagioclase, 9 mol.\% orthopyroxene, and 1 mol.\% ilmenite), alongside just $3 \mathrm{~mol} . \%$ melt. Extraction of previously generated melt has the main effect of raising the solidus temperature such that only a small amount of cooling is required before all retained melt crystallises, producing an immediate-subsolidus assemblage comprising 43-44 mol.\% hornblende, 25-26 mol.\% plagioclase, 20-22 mol.\% augite, 8-9 mol.\% orthopyroxene, and $1 \mathrm{~mol} \% \%$ ilmenite at pressures between 5-7 kbar. In contrast to the closed-system scenario, a granulite-facies (orthopyroxene-bearing) assemblage would thus be preserved and further subsolidus cooling would likely have little effect on phase proportions, although minor biotite, garnet, and/or olivine could form depending on the exact $\mathrm{d} P / \mathrm{d} T$ of the exhumation path (Fig. 10d).

\section{DISCUSSION}

\section{Partial melting and the nature of the amphibolite-granulite transition}

Partial melting is a characteristic feature of high-grade metamorphism, such that upper amphibolite- and granulite-facies migmatites must comprise a substantial volumetric proportion of the middle and lower continental crust in both modern and ancient orogens (Brown, 2001). As these crustal levels are known to contain significant proportions of basic and intermediate rocks (Zandt \& Ammon, 1995; Gao et al., 1998; Condie, 1999), the newly formulated $a-x$ relations presented by Green et al. (2016) can be used to explore their petrologic evolution during metamorphism and provide improved insight into the formation of granulite terranes. Despite variations in the basic and intermediate bulk-rock 
compositions modelled in this work, many features of the calculated phase relations are common to each. Subsolidus amphibolite-facies phase assemblages are typically dominated by hornblende and plagioclase, with quartz and biotite being relatively more abundant in diorite than in MORB (Fig. 3). Epidote, augite, garnet, muscovite, sphene, and/or ilmenite also variably occur, but in minor proportions $(<$ to $\ll 10 \mathrm{~mol}$.\% in total). These mineral assemblages and proportions correlate well with those present in exhumed subsolidus metabasites and intermediate 'grey' gneisses (e.g. Blattner, 1976; Pattison et al., 2003; Vernon \& Clarke, 2009; Moyen \& Martin, 2012; Weller et al., 2015).

For the fully hydrated compositions in each of the calculated $P-T$ pseudosections, the wet solidus shows a temperature minimum at pressures of 9-12 kbar, consistent with that inferred from fluid-saturated experimental studies performed in basaltic systems (e.g. Yoder \& Tilley, 1962; Wyllie \& Wolf, 1993). At these pressures, the calculated solidus is located below $650{ }^{\circ} \mathrm{C}$, reaching approximately $610{ }^{\circ} \mathrm{C}$, and thus sits at temperatures below that inferred for metapelitic compositions (e.g. White et al., 2000; Thompson, 1982). At lower pressures, the metabasic solidus sits at higher temperature than that calculated by White et al. (2014a) for metapelites, with both solidi crossing at 6-10 kbar.

The first water-saturated partial melts produced from MORB and diorite protoliths are calculated to be granitic or trondhjemitic according to the modified TAS classification system of Middlemost (1994) (Fig. 8) and Niggli normative calculations (Fig. 9b). These melts contain similar wt\% $\mathrm{Na}_{2} \mathrm{O}$ and $\mathrm{K}_{2} \mathrm{O}$ contents at each pressure (Table 2), though are produced only in very small proportions. All calculated melt compositions become drier and progressively enriched in $\mathrm{Al}_{2} \mathrm{O}_{3}, \mathrm{CaO}, \mathrm{FeO}$, and $\mathrm{MgO}$ with increasing temperature, with the $\mathrm{Na}_{2} \mathrm{O}: \mathrm{K}_{2} \mathrm{O}$ ratios increasing. Higher- $P$ melt compositions are consistently more hydrous than those at lower- $P$ for any given temperature, in agreement with experimental studies and theoretical predictions (Burnham, 1979; Rapp et al., 1991). Above $800{ }^{\circ} \mathrm{C}$, Niggli norms suggest that partial melts derived from metabasalt become increasingly trondhjemitic/tonalitic, and those derived from metadiorite become increasingly granodioritic as temperature increases. Calculated phase proportions along these isobaric heating paths indicates that anatexis in MORB proceeds primarily via incongruent 
hydrate-breakdown of hornblende, as biotite does not persist far into the suprasolidus regime (Fig. 1). Melting largely produces peritectic augite, orthopyroxene, and ilmenite at low- to medium- $P$, and augite, garnet and rutile at high- $P$ (Figs 1 and $3 \mathrm{a}-\mathrm{b}$ ), with garnet and orthopyroxene only coexisting over a narrow pressure range at 9.5-10 kbar. Although experiments predict that there should be a slightly wider pressure interval of coexisting garnet-orthopyroxene-clinopyroxene (Wolf \& Wyllie, 1994; Rapp \& Watson, 1995; Springer \& Seck, 1997; Skjerlie \& Patiño Douce, 2002; Qian \& Hermann, 2013), this disparity may be due to the absence of key components in our modelling, such as $\mathrm{MnO}$, which are otherwise present in natural materials and stabilise garnet, for example, to lower pressures.

For the diorite composition, an up-temperature expansion of the stability field for biotite and a reduction in the stability field for hornblende to lower temperatures in the suprasolidus regime (Fig. 2) results in the complete consumption of both hydrous phases over a narrow $20-30{ }^{\circ} \mathrm{C}$ interval at medium- $P$ conditions, which is also associated with a sharp increase in melt production (Fig. 3c). At higher-grade hornblende- and biotite-absent conditions, further melting occurs via the consumption of anhydrous plagioclase, orthopyroxene, augite, garnet, and/or quartz. Diorite is predicted to be significantly more fertile than MORB, with $\sim 80 \mathrm{~mol} . \%$ partial melt calculated to have formed at $1050{ }^{\circ} \mathrm{C}$ at mid-crustal pressures for the former, compared to $50 \mathrm{~mol} . \%$ for the latter. However, such large melt proportions are very unlikely to accumulate during orogenesis given the extreme temperatures required and the likelihood of progressive melt loss. Furthermore, many metabasic rocks in the deep continental crust may be of intrusive origin, emplaced into relatively dry crust, and therefore were never fully hydrated (Yardley \& Valley, 1997). In such rocks, granulite-facies assemblages are predicted to be stable below the solidus, which is likely to be situated between 800 and $900{ }^{\circ} \mathrm{C}$ for most crustal pressures (Fig. 4).

Although our MORB-derived calculated melt compositions are generally similar to analyses of experimentally derived glasses in $\mathrm{CaO}-\mathrm{Na}_{2} \mathrm{O}-\mathrm{K}_{2} \mathrm{O}$ wt\% oxide compositional space (Fig. 9), it is often preferable to consider general compositional trends as functions of $P$ and/or $T$, rather than the absolute values of particular components, as correlations between the $\mathrm{CaO}: \mathrm{K}_{2} \mathrm{O}: \mathrm{Na}_{2} \mathrm{O}$ ratio of starting materials and their associated partial melts 
have been noted in many cases (e.g. Rapp et al., 1991; Moyen, 2011). High- $P$ metabasite-derived partial melts are more aluminous and hydrous than lower- $P$ melts formed at equivalent temperatures, and have higher $\mathrm{Na}_{2} \mathrm{O} /\left(\mathrm{Na}_{2} \mathrm{O}+\mathrm{CaO}+\mathrm{K}_{2} \mathrm{O}\right)$ at low- $T$ conditions (Beard \& Lofgren, 1991; Springer \& Seck, 1997). Such compositional patterns are reproduced in our modelling for a MORB protolith using the recently formulated Green et al. (2016) $a-x$ relations (Table 2). Equivalent calculations using the metapelite melt model (White et al., 2007) and ds55-compatible amphibole and pyroxene models (Diener \& Powell, 2012) to investigate partial melting of basic protoliths, as has been attempted in some studies (e.g. Nagel et al., 2012), produces results inconsistent with these experimental data. Overall, such melts are relatively more hydrous $(\sim 20-55 \%)$, potassic $(\sim 15-45 \%)$ and sodic $(\sim 10-35 \%)$, and less calcic $(\sim 30-65 \%)$ and aluminous $(\sim 0-10 \%)$ than those produced using the Green et al. (2016) $a-x$ relations at equivalent $P-T-M_{\mathrm{H}_{2} \mathrm{O}}$ conditions (values are given as relative percentages).

The amphibolite-granulite transition in basic and intermediate bulk-rock compositions at low- and medium- $P$ is marked by the prograde stabilisation of orthopyroxene (Eskola, 1920), which occurs in garnet-absent assemblages at $780-900{ }^{\circ} \mathrm{C}$ for MORB (Fig. 1) and 750-840 ${ }^{\circ} \mathrm{C}$ for diorite (Fig. 2). Major-element oxide variations between different basalt types (Table 1) appear to exhibit minimal control on orthopyroxene stability (Fig. 7c), with bulk-rock compositional differences largely being accommodated by changes in the phase compositions and proportions. However, even minor changes in bulk-rock $\mathrm{H}_{2} \mathrm{O}$ content or oxidation state can strongly affect both subsolidus and suprasolidus phase relations in $\mathrm{MORB}$, with an increased bulk-rock $M_{\mathrm{O}}$ causing the amphibolite-granulite transition to migrate to higher temperatures by $20-25^{\circ} \mathrm{C}$ for every 0.1 increment (Fig. 5a) and destabilising garnet at high pressures (Fig. 5b) due to increasing the effective bulk-rock $X_{\mathrm{Mg}}$. In fluid-undersaturated MORB bulk compositions, the solidus is similarly elevated and orthopyroxene may form at subsolidus conditions at temperatures as low as $600{ }^{\circ} \mathrm{C}$ (Fig. 4a). Thus, the $P-T$ conditions normally inferred for the amphibolite -granulite facies boundary are only appropriate for well-hydrated metabasic compositions. The location of the solidus during cooling is also strongly controlled by the degree of melt loss that occurs in an open-system environment. The preservation of 
granulite-facies mineral assemblages is thus assisted by melt drainage (Fig. 10), as continued reaction or textural modification of existing assemblages is retarded both by the lack of an intercrystalline fluid through which diffusion can occur and due to the loss of water needed to form low-T hydrous phases (e.g. Pattison \& Begin, 1994).

\section{Variations in natural metabasic assemblages}

The calculations undertaken on representative basalt compositions show a relatively small range in mineral assemblages for different key basalt types (Figs 6 and 7c). However, metabasic amphibolites and granulites may show a considerable degree of variation in assemblages and mineral proportions over a small spatial area, for example with paired garnet-absent and garnet-present, or orthopyroxene-absent and orthopyroxene-present rocks coexisting at the same interpreted $P-T$ conditions (e.g. Hartel \& Pattison, 1996; Johnson et al., 2012). While the calculations shown here only cover a limited range of bulk-rock composition, the wider range of assemblages seen in natural high-grade metabasic rocks can be interpreted in several ways.

Chemical components that are not considered in the NCKFMASHTO model system may influence equilibrium phase assemblages in natural lithologies. For example, garnet is calculated to be stable above $\sim 9$ kbar for all unaltered basalt types (Fig. 7c), yet even small amounts of $\mathrm{MnO}$ can significantly increase its stability to lower pressure and temperature conditions in metapelites (cf. White et al., 2014b), albeit where it occurs in minor proportions. Though $\mathrm{MnO}$ is not incorporated into the $a-x$ relations presented by Green et al. (2016) for petrological investigation of basic and intermediate rocks, average MORB contains 0.16 wt\% MnO (Sun \& McDonough, 1989), which is comparable to that for a typical amphibolite-facies pelite (0.18 wt\%; Ague, 1991). Future model development should aim to incorporate $\mathrm{MnO}$ into relevant metabasic $a-x$ relations in order to quantitatively assess its importance on calculated equilibria. Likewise, the upper temperature limit of hornblende and biotite stability in natural rocks may be influenced by non-modelled elements such as F (e.g. Petersen et al., 1982).

Alternatively, mineralogical variation in natural metabasic assemblages is consistent 
with protoliths having a broader compositional range than that inferred from analyses of fresh, unaltered basalts. Submarine basaltic lavas are prone to various types of hydrothermal alteration, such as serpentinisation, spilitisation, and rodingitisation (Levi et al., 1982; Etheridge et al., 1983; Putnis \& Austrheim, 2010), and basalts extruded at the Earth's surface are subject to various degrees of weathering prior to metamorphism, each of which will modify the protolith bulk composition accordingly. Furthermore, interaction of basic rocks with fluids at low-grade metamorphic conditions can alter their composition (White et al., 2014c). Some cordierite-orthoamphibole gneisses (COGs) are thought to represent amphibolite- and granulite-facies equivalents of basic lavas that have been extensively metasomatised in seafloor hydrothermal systems (e.g. Tilley, 1935; Vallance, 1967; Chinner \& Fox, 1974; Seyfried \& Mottl, 1982; Smith et al., 1992; Johnson \& Oliver, 2002). These lithologies are typically strongly depleted in Ca and alkali elements, and enriched in $\mathrm{Mg}, \mathrm{Fe}$, and $\mathrm{Al}$ relative to unaltered basalt (Roberts et al., 2003). Comparative phase equilibria modelling of modern MORB and an average COG bulk composition by Diener et al. (2008) showed that these altered lithologies will generally lack diopsidic clinopyroxene, hornblende, epidote, and sphene at amphibolite-facies $P-T$ conditions, instead forming Fe-Mg-rich phases such as cordierite, cummingtonite, and/or anthophyllite. In addition, appreciable talc, kyanite, and/or paragonite may form at medium- or high- $P$ in a COG composition (>5 kbar; Diener et al., 2008), none of which is calculated to be stable in the unaltered basalt bulk compositions considered in this work (Figs 1 and 7). As there exist a number of likely mechanisms by which the compositions of natural amphibolites may be changed, whether contemporaneous with (Johnson \& Oliver, 2002) or prior to (Peck \& Smith, 2005) high-grade metamorphism, a substantial range in composition in amphibolites compared with their protoliths is to be expected, which will in turn be reflected in the mineral assemblages produced.

\section{Concluding remarks}

The newly calibrated $a-x$ relations presented by Green et al. (2016) allow detailed quantitative investigation of high-grade metamorphism and partial melting of basic and 
intermediate rock types at $P-T$ conditions typical of crustal metamorphism, which we have previously been unable to achieve. In particular, these limitations have restricted our ability to use calculated phase equilibria modelling to address the evolution of high-grade Archaean terranes, which are commonly dominated by TTG lithologies derived from anatexis of basic protoliths (e.g. Moyen \& Martin, 2012). Use of the new $a-x$ relations in investigations of such terranes may provide new and potentially more robust constraints on $P-T$ conditions of metamorphism and melt generation on the early Earth. Such studies may be integrated with large-scale geodynamic modelling (Johnson et al., 2014; Sizova et al., 2015) to investigate the tectonic environments of continental crust formation, or to examine the petrological consequences of secular cooling of the mantle throughout geological time (cf. Korenaga, 2006; Herzberg et al., 2010; Palin \& White, 2016). Future developments planned for these $a-x$ relations - especially with regards the metabasite melt and clinopyroxene models - will encompass higher pressure melt equilibria that can be used to investigate anatexis at eclogite-facies conditions. Such developments are necessary to allow a full discussion of growth of the Earth's earliest continental crust.

\section{Acknowledgements}

The authors acknowledge DFG grant WH 110/4-1 awarded to Richard White. Tim Johnson, Dave Pattison, and Simon Harley are thanked for highly detailed and insightful reviews, and Mike Brown is thanked for his efficient editorial handling.

\section{References}

Ague, J. J., 1991. Evidence for major mass transfer and volume strain during regional metamorphism of pelites. Geology, 19, 855-858.

Beard, J. S. \& Lofgren, G. E., 1991. Dehydration melting and water-saturated melting of basaltic andesitic greenstones and amphibolites at 1, 3, and 6.9 kbar. Journal of Petrology, 32, 365-401. 
Binns, R. A., 1965. The mineralogy of metamorphosed basic rocks from the Willyama Complex, Broken Hill district, New South Wales. Part I: Hornblendes. Mineralogical Magazine, 35, 306-326.

Blattner, P., 1976. Replacement of hornblende by garnet in granulite-facies assemblages near Milford Sound, New Zealand. Contributions to Mineralogy and Petrology, 55, 181-190.

Brown, M., 2001. Orogeny, migmatites and leucogranites: A review. Proceedings of the Indian Academy of Sciences (Earth and Planetary Sciences), 110, 313-336.

Brown, M., 2002. Retrograde processes in migmatites and granulites revisited. Journal of Metamorphic Geology, 20, 25-40.

Brown, M., 2007a. Crustal melting and melt extraction, ascent and emplacement in orogens: mechanisms and consequences. Journal of the Geological Society of London, 164, 709-730.

Brown, M., 2007b. Metamorphic conditions in orogenic belts: a record of secular change. International Geology Review, 49, 193-134.

Burnham, C. W., 1979. The importance of volatile constituents. In: The Evolution of the Igneous Rocks, (ed. Yoder, H. S.). Princeton, NJ: Princeton University Press, pp. $439-482$

Chinner, G. A. \& Fox, J. S., 1974. The origin of cordierite-anthophyllite rocks in the Land's End aureole. Geological Magazine, 111, 397-408.

Christensen, N. I. \& Mooney, W. D., 1995. Seismic velocity structure and composition of the continental crust: A global view. Journal of Geophysical Research: Solid Earth, 100(B6), 9761-9788.

Condie, K. C., 1999. Mafic crustal xenoliths and the origin of the lower continental crust. Lithos, 46, 95-101. 
Dale, J., Powell, R., White, R. W., Elmer, F. L. \& Holland, T. J. B., 2005. A thermodynamic model for $\mathrm{Ca}-\mathrm{Na}$ clinoamphiboles in $\mathrm{Na}_{2} \mathrm{O}-\mathrm{CaO}-\mathrm{FeO}-\mathrm{MgO}-\mathrm{Al}_{2} \mathrm{O}_{3}-\mathrm{SiO}_{2}-\mathrm{H}_{2} \mathrm{O}-\mathrm{O}$ for petrological calulations. Journal of Metamorphic Geology, 23, 771-791.

Diener, J. F. A. \& Fagereng, A., 2014. The influence of melting and melt drainage on crustal rheology during orogenesis. Journal of Geophysical Research: Solid Earth, 119, 6193-6210.

Diener, J. F. A. \& Powell, R., 2010. Influence of ferric iron on the stability of mineral assemblages. Journal of Metamorphic Geology, 28, 599-613.

Diener, J. F.A.\& Powell, R., 2012. Revised activity-composition relations for clinopyroxene and amphibole. Journal of Metamorphic Geology, 30, 131-142.

Diener, J. F. A., Powell, R. \& White, R. W., 2008. Quantitative phase petrology of cordierite-orthoamphibole gneisses and related rocks. Journal of Metamorphic Geology, 26, 795-814.

Diener, J. F. A., Powell, R., White, R. W. \& Holland, T. J. B., 2007. A new thermodynamic model for clino- and orthoamphiboles in the system $\mathrm{Na}_{2} \mathrm{O}-\mathrm{CaO}-\mathrm{FeO}-\mathrm{MgO}-\mathrm{Al}_{2} \mathrm{O}_{3}-\mathrm{SiO}_{2}-\mathrm{H}_{2} \mathrm{O}-\mathrm{O}$. Journal of Metamorphic Geology, 25, 631-656.

Diener, J. F. A., White, R. W. \& Hudson, T. J. M., 2014. Melt production, redistribution and accumulation in mid-crustal source rocks, with implications for crustal-scale melt transfer. Lithos, 200-201, 212-225.

Dougan, T. W., 1977. The Imataca Complex near Cerro Bolivar, Venezuela -a calc-alkaline Archean protolith. Precambrian Research, 4, 237-268.

Downes, H., 1993. The nature of the lower continental crust of Europe: petrological and geochemical evidence from xenoliths. Physics of the Earth and Planetary Interiors, 79, 195-218. 
England, P. C. \& Thompson, A. B., 1986. Some thermal and tectonic models for crustal melting in continental collision zones. In: Collision Tectonics, (eds Coward, M. \& Ries, A.), Vol. 19, pp. 83-94. Geological Society of London, Special Publications.

Eskola, P., 1920. The mineral facies of rocks. Norges Geologisk Tiddskrift, 6, 143-194.

Etheridge, M. A., Wall, V. J. \& Vernon, R. H., 1983. The role of the fluid phase during regional metamorphism and deformation. Journal of Metamorphic Geology, 1, 205-226.

Fyfe, W. S., 1970. Some thoughts on granite magmas. In: Mechanisms of Igneous Intrusions, (eds Newall, G. \& Rast, N.), Vol. 2, pp. 201-216. Gallery Press, Liverpool.

Fyfe, W. S., 1973. The granulite facies, partial melting, and the Archaean crust. Philosophical Transactions of the Royal Society of London, A273, 457-461.

Gao, S., Zhang, B. R., Jin, Z. M., Kern, H., Luo, T. C. \& Zhao, Z. D., 1998. How mafic is the lower continental crust? Earth and Planetary Science Letters, 161, 101-117.

Green, E. C. R., Holland, T. J. B. \& Powell, R., 2007. An order-disorder model for omphacitic pyroxenes in the system jadeite-diopside-hedenbergite-acmite, with applications to eclogitic rocks. American Mineralogist, 92, 1181-1189.

Green, E. C. R., White, R. W., Diener, J. F. A., Powell, R., Holland, T. J. B. \& Palin, R. M., 2016. Activity-composition relations for the calculation of partial melting equilibria for metabasic rocks. Journal of Metamorphic Geology, in press.

Guilmette, C., Indares, A. \& Hébert, R., 2011. High-pressure anatectic paragneisses from the Namche Barwa, Eastern Himalayan Syntaxis: Textural evidence for partial melting, phase equilibria modeling and tectonic implications. Lithos, 124, 66-81.

Harley, S. L., 1988. Proterozoic granulites from the Rauer Group, East Antarctica. I. Decompressional pressure-temperature paths deduced from mafic and felsic gneisses. Journal of Petrology, 29, 1059-1095. 
Hartel, T. H. D. \& Pattison, D. R. M., 1996. Genesis of the Kapuskasing (Ontario) migmatitic mafic granulites by dehydration melting of amphibolite: the importance of quartz to reaction progress. Journal of Metamorphic Geology, 14, 591-611.

Herzberg, C., Condie, K. C. \& Korenaga, J., 2010. Thermal history of the Earth and its petrological expression. Earth and Planetary Science Letters, 292, 79-88.

Holland, T. J. B. \& Powell, R., 2001. Calculation of phase relations involving haplogranitic melts using an internally consistent thermodynamic dataset. Journal of Petrology, 42, 673-683.

Holland, T. J. B. \& Powell, R., 2003. Activity-composition relations for phases in petrological calculations: an asymmetric multicomponent formulation. Contributions to Mineralogy and Petrology, 145, 492-501.

Holland, T. J. B. \& Powell, R., 2011. An improved and extended internally consistent thermodynamic dataset for phases of petrological interest, involving a new equation of state for solids. Journal of Metamorphic Geology, 29, 333-383.

Indares, A., White, R. W. \& Powell, R., 2008. Phase equilibria modelling of kyanite-bearing anatectic paragneisses from the central Grenville Province. Journal of Metamorphic Geology, 26, 815-836.

Janoušek, V., Gerdes, A., Vrána, S., Finger, F., Erban, V., Friedl, G. \& Braithwaite, C. J. R., 2006. Low-pressure granulites of the Lišov Massif, southern Bohemia: Viséan metamorphism of Late Devonian plutonic arc rocks. Journal of Petrology, 47, 705-744.

Jiang, N., Guo, J. \& Chang, G., 2013. Nature and evolution of the lower crust in the eastern North China craton: A review. Earth-Science Reviews, 122, 1-9.

Johnson, S. P. \& Oliver, G. J. H., 2002. High $f \mathrm{O}_{2}$ metasomatism during whiteschist metamorphism, Zambezi Belt, northern Zimbabwe. Journal of Petrology, 43, 271-290.

Johnson, T.E. \& White, R. W., 2011. Phase equilibrium constraints on conditions of granulite-facies metamorphism at Scourie, NW Scotland. Journal of the Geological Society of London, 168, 147-158. 
Johnson, T. E., Brown, M., Kaus, B. \& VanTongeren, J., 2014. Delamination and recycling of Archaean crust caused by gravitational instabilities. Nature Geoscience, 7, 47-52.

Johnson, T. E., Fischer, S., White, R. W., Brown, M. \& Rollinson, H. R., 2012. Archaean intracrustal differentiation from partial melting of metagabbro: field and geochemical evidence from the central region of the Lewisian Complex, NW Scotland. Journal of Petrology, 53, 2115-2138.

Jöns, N. \& Schenk, V., 2008. Relics of the Mozambique Ocean in the central East African Orogen: evidence from the Vohibory Block of southern Madagascar. Journal of Metamorphic Geology, 26, 17-28.

Korenaga, J., 2006. Archean geodynamics and the thermal evolution of the Earth. In: Archean Geodynamics and Environments, (eds Benn, K., Mareschal, J. C. \& Condie, K. C.), Vol. 164 of Geophysical Monograph Series, pp. 7-32. American Geophysical Union, Washington, DC.

Korhonen, F. J., Brown, M., Clark, C. \& Bhattacharya, S., 2013. Osumilite-melt interactions in ultrahigh temperature granulites: phase equilibria modelling and implications for the $P-T-t$ evolution of the Eastern Ghats Province, India. Journal of Metamorphic Geology, 31, 881-907.

Le Bas, M. J., Le Maitre, R. W., Streckeisen, A. L. \& Zanettin, B., 1986. A chemical classification of volcanic rocks based on the Total Alkali-Silica diagram. Journal of Petrology, 27, 745-750.

Levi, B., Aguirre, L. \& Nyström, J. O., 1982. Metamorphic gradients in burial metamorphosed vesicular lavas: comparison of basalt and spilite in Cretaceous basic flows from central Chile. Contributions to Mineralogy and Petrology, 80, 49-58.

López, S. \& Castro, A., 2001. Determination of the fluid-absent solidus and supersolidus phase relationships of MORB-derived amphibolites in the range 4-14 kbar. American Mineralogist, 86, 1396-1403. 
Macdonald, G. A., 1968. Composition and origin of Hawaiian lavas. Geological Society of America Memoirs, 116, 477-522.

Mallmann, G. \& O'Neill, H. S. C., 2009. The crystal/melt partitioning of V during mantle melting as a function of oxygen fugacity compared with some other elements (Al, P, Ca, Sc, Ti, Cr, Fe, Ga, Y, Zr and Nb). Journal of Petrology, 50, 1765-1794.

Mason, A. J. \& Brewer, T. S., 2005. A re-evaluation of a Laxfordian terrane boundary in the Lewisian Complex of South Harris, NW Scotland. Journal of the Geological Society of London, 162, 401-407.

Middlemost, E.A. K., 1994. Naming materials in the magma/igneous rock system. Earth-Science Reviews, 37, 215-224.

Montanini, A. \& Tribuzio, R., 2001. Gabbro-derived granulites from the Northern Apennines (Italy): Evidence for lower-crustal emplacement of tholeiitic liquids in post-Variscan times. Journal of Petrology, 42, 2259-2277.

Moyen, J. F., 2011. The composite Archaean grey gneisses: petrological significance, and evidence for a non-unique setting for Archaean crustal growth. Lithos, 123, 21-36.

Moyen, J.F. \& Martin, H., 2012. Forty years of TTG research. Lithos, 148, 312-336.

Nagel, T. J., Elis Hoffmann, J. \& Münker, C., 2012. Generation of Eoarchean tonalite-trondhjemite-granodiorite series from thickened mafic arc crust. Geology, 40, 375-378.

Nielsen, C. \& Sigurdsson, H., 1981. Quantitative methods for electron microprobe analysis of sodium in natural and synthetic glasses. American Mineralogist, 66, 547-552.

Niggli, P., 1936. Über Molekularnormen zur Gesteinsberechnung. Schweizerische Mineralogische und Petrographische Mitteilungen, 16, 295-317.

Nockolds, S. R. \& Le Bas, M. J., 1977. Average calc-alkali basalt. Geological Magazine, 114, 311-312. 
O’Brien, P. J. \& Rötzler, J., 2003. High-pressure granulites: formation, recovery of peak conditions and implications for tectonics. Journal of Metamorphic Geology, 21(1), 3-20.

Palin, R. M. \& White, R. W., 2016. Emergence of blueschists on Earth linked to secular changes in oceanic crust composition. Nature Geoscience, 9, 60-64.

Palin, R. M., Searle, M. P., Morley, C. K., Charusiri, P., Horstwood, M. S. A. \& Roberts, N. M. W., 2013b. Timing of metamorphism of the Lansang gneiss and implications for motion along the Mae Ping (Wang Chao) strike-slip fault, Thailand. Journal of Asian Earth Sciences, 76, 120-136.

Palin, R. M., Searle, M. P., Waters, D. J., Parrish, R. R., Roberts, N. M. W., Horstwood, M. S. A., Yeh, M. W., Chung, S. L. \& Anh, T. T., 2013a. A geochronological and petrological study of anatectic paragneiss and associated granite dykes from the Day Nui Con Voi metamorphic core complex, North Vietnam; constraints upon the timing of metamorphism within the Red River shear zone. Journal of Metamorphic Geology, 31, 359-387.

Palin, R. M., St-Onge, M. R., Waters, D. J., Searle, M. P. \& Dyck, B., 2014. Phase equilibria modelling of retrograde amphibole and clinozoisite in mafic eclogite from the Tso Morari massif, northwest India: constraining the $P-T-M\left(\mathrm{H}_{2} \mathrm{O}\right)$ conditions of exhumation. Journal of Metamorphic Geology, 32, 675-693.

Palin, R. M., Weller, O. M., Waters, D. J. \& Dyck, B., 2016. Quantifying geological uncertainty in metamorphic phase equilibria modelling; a Monte Carlo assessment and implications for tectonic interpretations. Geoscience Frontiers, 7, 591-607.

Park, R. G., 1966. Nature and origin of Lewisian basic rocks of Gairloch, Ross-shire. Scottish Journal of Geology, 2, 179-199.

Patiño Douce, A. E. \& Beard, J. S., 1995. Dehydration melting of biotite gneiss and quartz amphibolite from 3 to 15 kbar. Journal of Petrology, 36, 707-738.

Pattison, D. R. M., 2003. Petrogenetic significance of orthopyroxene-free garnet + 
clinopyroxene + plagioclase \pm quartz-bearing metabasites with respect to the amphibolite and granulite facies. Journal of Metamorphic Geology, 21, 21-34.

Pattison, D. R. M. \& Begin, N. J., 1994. Zoning patterns in orthopyroxene and garnet in granulites: implications for geothermometry. Journal of Metamorphic Geology, 12, 387-410.

Pattison, D. R. M., Chacko, T., Farquhar, J. \& McFarlane, C. R. M., 2003. Temperatures of granulite-facies metamorphism: constraints from experimental phase equilibria and thermobarometry corrected for retrograde exchange. Journal of Petrology, 44, 867-900.

Peck, W. H. \& Smith, M. S., 2005. Cordierite-gedrite rocks from the Central Metasedimentary Belt boundary thrust zone (Grenville Province, Ontario): Mesoproterozoic metavolcanic rocks with affinities to the Composite Arc Belt. Canadian Journal of Earth Sciences, 42, 1815-1828.

Petersen, E. U., Essene, E. J. \& Peacor, D. R., 1982. Fluorine end-member micas and amphiboles. American Mineralogist, 67, 538-544.

Phillips, G. N., 1980. Water activity changes across an amphibolite-granulite facies transition, Broken Hill, Australia. Contributions to Mineralogy and Petrology, 75, 377-386.

Pitcher, W. S., Atherton, M. P., Cobbing, E. J. \& Beckinsale, R. D., 1985. Magmatism at a plate edge: The Peruvian Batholith, Glasgow, Blackie and Sons, p. 273-284.

Powell, R. \& Downes, J., 1990. Garnet porphyroblast-bearing leucosomes in metapelites: mechanisms, phase diagrams and an example from Broken Hill, Australia. In: High-temperature Metamorphism and Crustal Anatexis, (ed. J. R. Ashworth et al.), chapter 5, pp. 105-123. Springer Netherlands.

Powell, R. \& Holland, T. J. B., 1988. An internally consistent dataset with uncertainties and correlations: 3. Applications to geobarometry, worked examples and a computer program. Journal of Metamorphic Geology, 6, 173-204. 
Powell, R. \& Holland, T. J. B., 2008. On thermobarometry. Journal of Metamorphic Geology, 26, 155-179.

Putnis, A. \& Austrheim, H., 2010. Fluid-induced processes: metasomatism and metamorphism. Geofluids, 10, 254-269.

Qian, Q. \& Hermann, J., 2013. Partial melting of lower crust at 10-15 kbar: constraints on adakite and TTG formation. Contributions to Mineralogy and Petrology, 165, 1195-1224.

Rapp, R. P. \& Watson, E. B., 1995. Dehydration melting of metabasalt at 8-32 kbar: implications for continental growth and crust-mantle recycling. Journal of Petrology, 36, 891-931.

Rapp, R. P., Watson, E. B. \& Miller, C. F., 1991. Partial melting of amphibolite/eclogite and the origin of Archaean trondhjemites and tonalites. In: Precambrian Granitoids-Petrogenesis, Geochemistry and Metallogeny, (eds Haapala, I. \& Condie, K. C.), Vol. 51, pp. 1-25.

Rebay, G., Powell, R. \& Diener, J. F. A., 2010. Calculated phase equilibria for a MORB composition in a $P-T$ range, $450-650^{\circ} \mathrm{C}$ and $18-28$ kbar: the stability of eclogite. Journal of Metamorphic Geology, 28, 635-645.

Renner, J., Evans, B. \& Hirth, G., 2000. On the rheologically critical melt fraction. Earth and Planetary Science Letters, 181, 585-594.

Roberts, M. D., Oliver, N. H. S., Fairclough, M. C., Hölttä, P. S. \& Lahtinen, R., 2003. Geochemical and oxygen isotope signature of sea-floor alteration associated with a polydeformed and highly metamorphosed massive sulphide seposit, Ruostesuo, central Finland. Economic Geology, 98, 535-556.

Rosenberg, C. L. \& Handy, M. R., 2005. Experimental deformation of partially melted granite revisited: implications for the continental crust. Journal of Metamorphic Geology, 23, 19-28. 
Rudnick, R. L. \& Taylor, S. R., 1987. The composition and petrogenesis of the lower crust: A xenolith study. Journal of Geophysical Research: Solid Earth, 92(B13), 13981-14005.

Rushmer, T., 1991. Partial melting of two amphibolites: contrasting experimental results under fluid-absent conditions. Contributions to Mineralogy and Petrology, 107, 41-59.

Sawyer, E. W., 2001. Melt segregation in the continental crust: Distribution and movement of melt in anatectic rocks. Journal of Metamorphic Geology, 19, 291-309.

Schilling, J.-G., Zajec, M., Evans, R., Johnston, T., White, W., Devine, J. D. \& Kingsley, R., 1983. Petrologic and geochemical variations along the Mid-Atlantic Ridge from $27^{\circ} \mathrm{N}$ to $73^{\circ}$ N. American Journal of Science, 283, 510-586.

Seyfried, W. E. \& Mottl, M. J., 1982. Hydrothermal alteration of basalt by seawater under seawater-dominated conditions. Geochimica et Cosmochimica Acta, 46, 985-1002.

Silver, L. \& Stolper, E., 1989. Water in albitic glasses. Journal of Petrology, 30, 667-709.

Sizova, E., Gerya, T., Stüwe, K. \& Brown, M., 2015. Generation of felsic crust in the Archean: A geodynamic modeling perspective. Precambrian Research, 271, 198-224.

Skjerlie, K.P. \& Patiño Douce, A. E., 1995. Anatexis of interlayered amphibolite and pelite at 10kbar: effect of diffusion of major element components on phase relations and melt fraction. Contributions to Mineralogy and Petrology, 122, 67-78.

Skjerlie, K. P. \& Patiño Douce, A. E., 2002. The fluid-absent partial melting of a zoisite-bearing quartz eclogite from 1.0 to $3.2 \mathrm{GPa}$; implications for melting in thickened continental crust and for subduction zone processes. Journal of Petrology, 43, 291-314.

Smith, M. S., Dymek, R. F. \& Schneiderman, J. S., 1992. Implications of trace element geochemistry for the origin of cordierite-anthophyllite rocks from Orijärvi, SW Finland. Journal of Geology, 100, 545-559.

Spear, F. S., 1981. An experimental study of hornblende stability and compositional variability in amphibole. American Journal of Science, 281, 697-734. 
Spear, F. S., 1993. Metamorphic phase equilibria and pressure-temperature-time paths, Mineralogical Society of America, 799 pp.

Spear, F. S., Kohn, M. J. \& Cheney, J. T., 1999. $P-T$ paths from anatectic pelites. Contributions to Mineralogy and Petrology, 134, 17-32.

Springer, W. \& Seck, H. A., 1997. Partial fusion of basic granulites at 5 to 15 kbar: implications for the origin of TTG magmas. Contributions to Mineralogy and Petrology, 127, 30-45.

Spulber, S. D. \& Rutherford, M. J., 1983. The origin of rhyolite and plagiogranite in oceanic crust: an experimental study. Journal of Petrology, 24, 1-25.

Sun, S.-S. \& McDonough, W. F., 1989. Chemical and isotopic systematics of oceanic basalts: implications for mantle compositions and processes. In: Magmatism in the Ocean Basins, (eds Saunders, A. \& Norry, M.), Vol. 42, pp. 313-345. Geological Society of London, Special Publications.

Thompson, A. B., 1982. Dehydration melting of pelitic rocks and the generation of $\mathrm{H}_{2} \mathrm{O}$-undersaturated granitic liquids. American Journal of Science, 282, 1567-1595.

Thompson, A. B. \& Connolly, J. A. D., 1995. Melting of the continental crust: Some thermal and petrological constraints on anatexis in continental collision zones and other tectonic settings. Journal of Geophysical Research, 100(B8), 15565-15579.

Tilley, C. E., 1935. Metasomatism associated with the greenstone-hornfelses of Kenidjack and Botallack, Cornwall. Mineralogical Magazine, 24, 181-202.

Vallance, T. G., 1967. Mafic rock alteration and isochemical development of some cordierite-anthophyllite rocks. Journal of Petrology, 8, 84-96.

Vernon, R. H. \& Clarke, G. L., 2009. Principles of Metamorphic Petrology, Cambridge University Press, 478 pp. 
Vernon, R. H., Collins, W. J. \& Cook, N. D. J., 2012. Metamorphism and deformation of mafic and felsic rocks in a mamga transfer zone, Stewart Island, New Zealand. Journal of Metamorphic Geology, 30, 473-488.

Vielzeuf, D., Clemens, J. D., Pin, C. \& Moinet, E., 1990. Granites, granulites, and crustal differentiation. In: Granulites and Crustal Evolution, (eds Vielzeuf, D. \& Vidal, P.), Vol. 311, NATO ASI Series, Kluwer Academic Publications, Dordrecht, pp. 59-86.

Vigneresse, J.-L., Barbey, P. \& Cuney, M., 1996. Rheological transitions during partial melting and crystallization with application to felsic magma segregation and transfer. Journal of Petrology, 37, 1579-1600.

Watkins, L., Clemens, J. D. \& Treloar, P. J., 2007. Archaean TTGs as sources of younger granitic magmas: melting of sodic metatonalites at 0.6-1.2 GPa. Contributions to Mineralogy and Petrology, 154, 91-110.

Weller, O. M., St-Onge, M. R., Searle, M. P., Waters, D. J., Rayner, N., Chen, S., Chung, S. L. \& Palin, R. M., 2015. Quantifying the $P-T-t$ conditions of north-south Lhasa terrane accretion: new insight into the pre-Himalayan architecture of the Tibetan plateau. Journal of Metamorphic Geology, 33, 91-113.

White, A. J. R., Legras, M., Smith, R. E. \& Nadoll, P., 2014c. Deformation-driven, regional-scale metasomatism in the Hamersley Basin, Western Australia. Journal of Metamorphic Geology, 32, 417-433.

White, R. W. \& Powell, R., 2002. Melt loss and the preservation of granulite-facies mineral assemblages. Journal of Metamorphic Geology, 20, 621-632.

White, R.W., Powell, R. \& Clarke, G. L., 2002. The interpretation of reaction textures in Fe-rich metapelitic granulites of the Musgrave Block, central Australia: constraints from mineral equilibria calculations in the system $\mathrm{K}_{2} \mathrm{O}-\mathrm{FeO}-\mathrm{MgO}-\mathrm{Al}_{2} \mathrm{O}_{3}-\mathrm{SiO}_{2}-\mathrm{H}_{2} \mathrm{O}-\mathrm{TiO}_{2}-\mathrm{Fe}_{2} \mathrm{O}_{3}$. Journal of Metamorphic Geology, 20, 41-55. 
White, R. W., Powell, R. \& Halpin, J. A., 2004. Spatially-focussed melt formation in aluminous metapelites from Broken Hill, Australia. Journal of Metamorphic Geology, 22, 825-845.

White, R. W., Powell, R. \& Holland, T. J. B., 2001. Calculation of partial melting equilibria in the system $\mathrm{Na}_{2} \mathrm{O}-\mathrm{CaO}-\mathrm{K}_{2} \mathrm{O}-\mathrm{FeO}-\mathrm{MgO}-\mathrm{Al}_{2} \mathrm{O}_{3}-\mathrm{SiO}_{2}-\mathrm{H}_{2} \mathrm{O}$ (NCKFMASH). Journal of Metamorphic Geology, 19, 139-153.

White, R. W., Powell, R. \& Holland, T. J. B., 2007. Progress relating to calculation of partial melting equilibria for metapelites. Journal of Metamorphic Geology, 25, 511-527.

White, R. W., Powell, R. \& Johnson, T. E., 2014b. The effect of Mn on mineral stability in metapelites revisited: new $a-x$ relations for manganese-bearing minerals. Journal of Metamorphic Geology, 32, 809-828.

White, R. W., Powell, R., Holland, T. J. B. \& Worley, B. A., 2000. The effect of $\mathrm{TiO}_{2}$ and $\mathrm{Fe}_{2} \mathrm{O}_{3}$ on metapelitic assemblages at greenschist and amphibolite facies conditions: mineral equilibria calculations in the system $\mathrm{K}_{2} \mathrm{O}-\mathrm{FeO}-\mathrm{MgO}-\mathrm{Al}_{2} \mathrm{O}_{3}-\mathrm{SiO}_{2}-\mathrm{H}_{2} \mathrm{O}-\mathrm{TiO}_{2}-\mathrm{Fe}_{2} \mathrm{O}_{3}$. Journal of Metamorphic Geology, 18, 497-511.

White, R. W., Powell, R., Holland, T. J. B., Johnson, T. E. \& Green, E. C. R., 2014a. New mineral activity-composition relations for thermodynamic calculations in metapelitic systems. Journal of Metamorphic Geology, 32, 261-286.

White, R. W., Stevens, G. \& Johnson, T. E., 2011. Is the crucible reproducible? Reconciling melting experiments with thermodynamic calculations. Elements, 7, 241-246.

Winther, K. T., 1996. An experimentally based model for the origin of tonalitic and trondhjemitic melts. Chemical Geology, 127, 43-59.

Wolf, M. B. \& Wyllie, P. J., 1994. Dehydration melting of amphibolite at 10 kbar: the effects of temperature and time. Contributions to Mineralogy and Petrology, 115, 369-383. 
Wyllie, P. J. \& Wolf, M. B., 1993. Amphibole dehydration-melting: sorting out the solidus. In: Magmatic processes and plate tectonics, (eds Pritchard, H., Alabaster, T., Harris, N. \& Neary, C.), Vol. 76, pp. 405-416. Geological Society of London Special Publications.

Yakymchuk, C. \& Brown, M., 2014. Consequences of open-system melting in tectonics. Journal of the Geological Society of London, 171, 21-40.

Yardley, B. W. D. \& Valley, J. W., 1997. The petrologic case for a dry lower crust. Journal of Geophysical Research, 102, 12173-12185.

Yoder, H. S. \& Tilley, C., 1962. Origin of basalt magmas: an experimental study of natural and synthetic rock systems. Journal of Petrology, 3, 342-532.

Zandt, G. \& Ammon, C. J., 1995. Continental crust composition constrained by measurements of crustal Poisson's ratio. Nature, 374, 152-154.

Zhang, C., Holtz, F., Koepke, J., Wolff, P. E., Ma, C. \& Bédard, J. H., 2013. Constraints from experimental melting of amphibolite on the depth of formation of garnet-rich restites, and implications for models of Early Archean crustal growth. Precambrian Research, 231, 206-217.

Ziaja, K., 2012. Forward modelling of petrological crust-forming process on the early Earth. PhD thesis, Johannes-Gutenberg Universität Mainz, Germany.

Zierenberg, R. A., Schiffman, P., Barfod, G. H., Lesher, C. E., Marks, N. E., Lowenstern, J. B., Mortensen, A. K., Pope, E. C., Bird, D. K., Reed, M. H., Fridleifsson, G. O. \& Elders, W. A., 2012. Composition and origin of rhyolite melt intersected by drilling in the Krafla geothermal field, Iceland. Contributions to Mineralogy and Petrology, 165, 327-347. 


\section{Table captions}

Table 1: Bulk-rock compositions used for phase diagram construction (mol.\% oxide). Data sources are: ${ }^{a}$ Sun \& McDonough (1989); ${ }^{b}$ Pitcher et al. (1985); ${ }^{\mathrm{c}}$ Macdonald (1968); dNockolds \& Le Bas (1977); ${ }^{\text {ePark }}$ (1966). FeO ${ }^{\text {tot }}$ is total iron expressed as FeO. $\mathrm{O}$ is oxygen, which combines with $\mathrm{FeO}$ via the equation $2 \mathrm{FeO}+\mathrm{O}=\mathrm{Fe}_{2} \mathrm{O}_{3}$; hence, bulk $\mathrm{O}$ is identically equal to bulk $\mathrm{Fe}_{2} \mathrm{O}_{3}$, while true bulk $\mathrm{FeO}$ is given by $\mathrm{FeO}^{\text {tot }}-2 \times \mathrm{O} \cdot X_{\mathrm{Mg}}=\mathrm{MgO} /(\mathrm{FeO}+\mathrm{MgO})$.

Table 2: Calculated melt compositions (wt\% oxide) at various $P-T$ conditions for MORB and diorite. Dagger $\left(^{\dagger}\right)$ represents the solidus temperature at each pressure.

Table 3: Bulk-rock composition of a Lewisian amphibolite (mol.\% oxide) following progressive melt-extraction events during isobaric heating at 7 kbar (cf. Fig. 10). Each melt-loss event is initiated when the modal proportion of melt reaches 7 mol.\%, at which point this is reduced to $1 \mathrm{~mol} \%$, and melt accumulation can begin again. $\downarrow$ represents a decreasing trend during heating, whereas $\uparrow$ represents an increasing trend. $\curvearrowright$ indicates that a component increases in proportion up to a certain point during heating and then decreases.

Table 1:

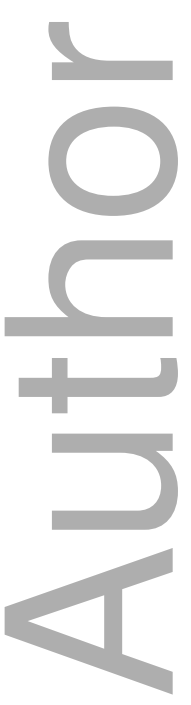

Table 2:

Table 3: 


\section{Figure captions}

Fig. 1: Calculated $P-T$ pseudosection for the MORB bulk composition of Sun \& McDonough (1989) showing equilibrium phase assemblages and contours for the modal proportion of melt (thin dashed lines). The solidus is represented by a bold line and the $\mathrm{H}_{2} \mathrm{O}$-out assemblage field boundary by a bold dashed line. The extent of biotite-bearing assemblages in the summary diagram on the right is marked by a stippled region.

Fig. 2: As for Fig. 1, but for the diorite bulk composition of Pitcher et al. (1985).

Fig. 3: Calculated changes in modal proportions of phases in MORB and diorite during increasing temperature between $600-1050{ }^{\circ} \mathrm{C}$ at various pressures. These calculations assume that no melt is lost during heating. Modeboxes for MORB at (a) $5 \mathrm{kbar}$ and (b) $10 \mathrm{kbar}$, and diorite at (c) 5 kbar and (d) 10 kbar.

Fig. 4: Binary pseudosections for MORB showing the effects of varying the molar proportion of $\mathrm{H}_{2} \mathrm{O}$ in the bulk composition at pressures of (a) 5 kbar and (b) $10 \mathrm{kbar}$. In each case, the original bulk composition used in Fig. 1a is denoted by a vertical dotted line. Contours for the modal proportion of melt are shown by numbered, thin dashed lines. The extents of biotite-bearing assemblages in summary diagrams are marked by stippled regions.

Fig. 5: Binary pseudosections for MORB showing the effects of varying the oxidation state of the bulk composition at pressures of (a) 5 kbar and (b) 10 kbar. In each case, the original bulk composition used in Fig. 1a is denoted by a vertical dotted line. Contours for the modal proportion of melt are shown by numbered, thin dashed lines. The compositional variable $\mathrm{x}(\mathrm{ilm})$ represents the proportion of ilmenite in the ilmenite-hematite solid solution.

Fig. 6: $T-X$ pseudosection calculated at 5 kbar showing phase assemblage changes in transitions between various basic and intermediate lithologies. Rock types are arranged on the diagram so as to produce general compositional trends from left to 
right, constituting a general increase in $\mathrm{SiO}_{2}, \mathrm{Al}_{2} \mathrm{O}_{3}, \mathrm{~K}_{2} \mathrm{O}$, and $\mathrm{Na}_{2} \mathrm{O}$, and a general decrease in $\mathrm{CaO}, \mathrm{MgO}, \mathrm{FeO}$, and $\mathrm{TiO}_{2}$. Bulk compositions used for calculations are given in Table 1. Note that MORB and calc-alkaline basalt compositions are not linear combinations of the ocean island basalt (OIB) and diorite diagram end members. The solidus is represented by a bold line and the $\mathrm{H}_{2} \mathrm{O}$-out assemblage field boundary by a bold dashed line. The extents of augite- and biotite-bearing assemblage fields are marked by dashed and stippled regions, respectively. Contours for the modal proportion of melt are shown by numbered, thin dashed lines.

Fig. 7: Calculated $P-T$ pseudosections for (a) calc-alkaline (Nockolds \& Le Bas, 1977) and (b) ocean island basalt (Macdonald, 1968) bulk compositions showing equilibrium phase assemblages and contours for the modal proportion of melt (thin dashed lines). The solidus is represented by a bold line and the $\mathrm{H}_{2} \mathrm{O}$-out assemblage field boundary by a bold dashed line. A comparison of the important phase assemblage boundaries and melt proportions calculated for MORB, calc-alkaline, and ocean island basalt bulk compositions is given in part (c). Modebox diagrams for (d) calc-alkaline basalt and (e) ocean island basalt represent closed-system phase changes during isobaric heating at 5 kbar.

Fig. 8: Modified total alkali-silica (TAS) diagrams showing calculated melt compositions for MORB and diorite protoliths at 5 and $10 \mathrm{kbar}$ (wt\% oxide) in terms of their plutonic lithological equivalent. Field boundaries and labels are after Middlemost (1994). Insets for both diagrams show calculated melt compositions for MORB and diorite protoliths at 5 and $10 \mathrm{kbar}$ in $\mathrm{CaO}-\mathrm{Na}_{2} \mathrm{O}-\mathrm{K}_{2} \mathrm{O}$ ternary compositional space. (a) Calculated melt compositions for MORB at 5 and 10 kbar. (b) Calculated melt compositions for diorite at 5 and $10 \mathrm{kbar}$.

Fig. 9: Ternary diagrams calculated for melts derived from MORB and diorite protoliths at 5 and 10 kbar. (a) Comparison to analysed glass compositions from experimental studies of hydrate-breakdown melting of basic protoliths (diamonds) in the $\mathrm{CaO}-\mathrm{Na}_{2} \mathrm{O}-\mathrm{K}_{2} \mathrm{O}$ ternary system. Dashed lines for our calculated partial melt compositions represent the traces of sub- $800{ }^{\circ} \mathrm{C}$ melts. All data are given as 
normalised proportions of wt\% oxides. Filled diamond symbols represent data from experiments conducted between 5-10 kbar; dashed diamonds represent data from outside of this pressure range. (b) Comparison of the proportions anorthite (An), albite (Ab), and orthoclase (Or) in natural TTGs (dashed and stippled fields) compared to of our 'crystallised melts' determined using Niggli normative calculations. Modified after Johnson et al. (2012). Data sources are as follows: BL91 - Beard \& Lofgren (1991); R91 - Rushmer (1991); WW94 - Wolf \& Wyllie (1994); PDB95 - Patiño Douce \& Beard (1995); RW95 - Rapp \& Watson (1995); SPD95 Skjerlie \& Patiño Douce (1995); W96 - Winther (1996); LC01 - López \& Castro (2001); SPD02 - Skjerlie \& Patiño Douce (2002); W07 - Watkins et al. (2007); Z12 Ziaja (2012); QH13 - Qian \& Hermann (2013); Z13 - Zhang et al. (2013).

Fig. 10: (a) Calculated $P-T$ pseudosection for a Lewisian amphibolite (Park, 1966). (b) Fractionated $P-T$ pseudosection showing the effects of successive melt-loss events during prograde metamorphism. Dashed lines labelled 7\% are modal proportion contours for melt generated for successive melt-depleted residuum bulk compositions. (c) Modebox diagrams showing the petrological evolution of the amphibolite in a closed-system (upper) and open-system (lower) environment during heating at 7 kbar. (d) $P-T$ pseudosection calculated for melt-depleted bulk composition 4 from Table 3, showing the preservation-potential of granulite-facies assemblages during retrogression due to melt loss. Star represents position of peak $P-T$ conditions used for discussion and arrows represent potential retrograde cooling/decompression paths. Dashed lines represent the modal proportion of orthopyroxene.

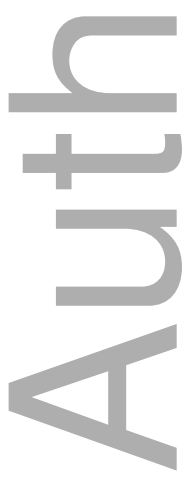



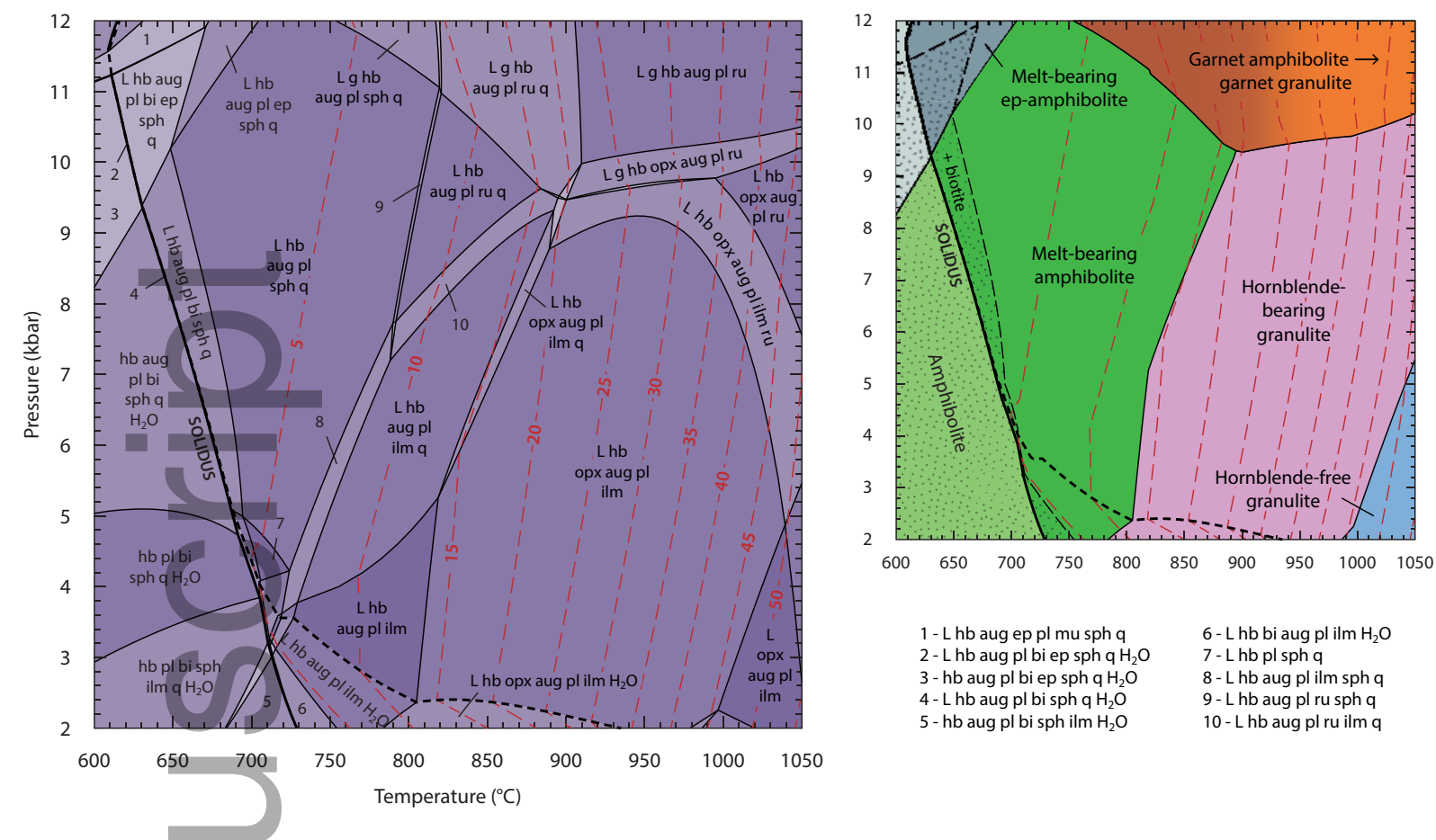

Figure 1:
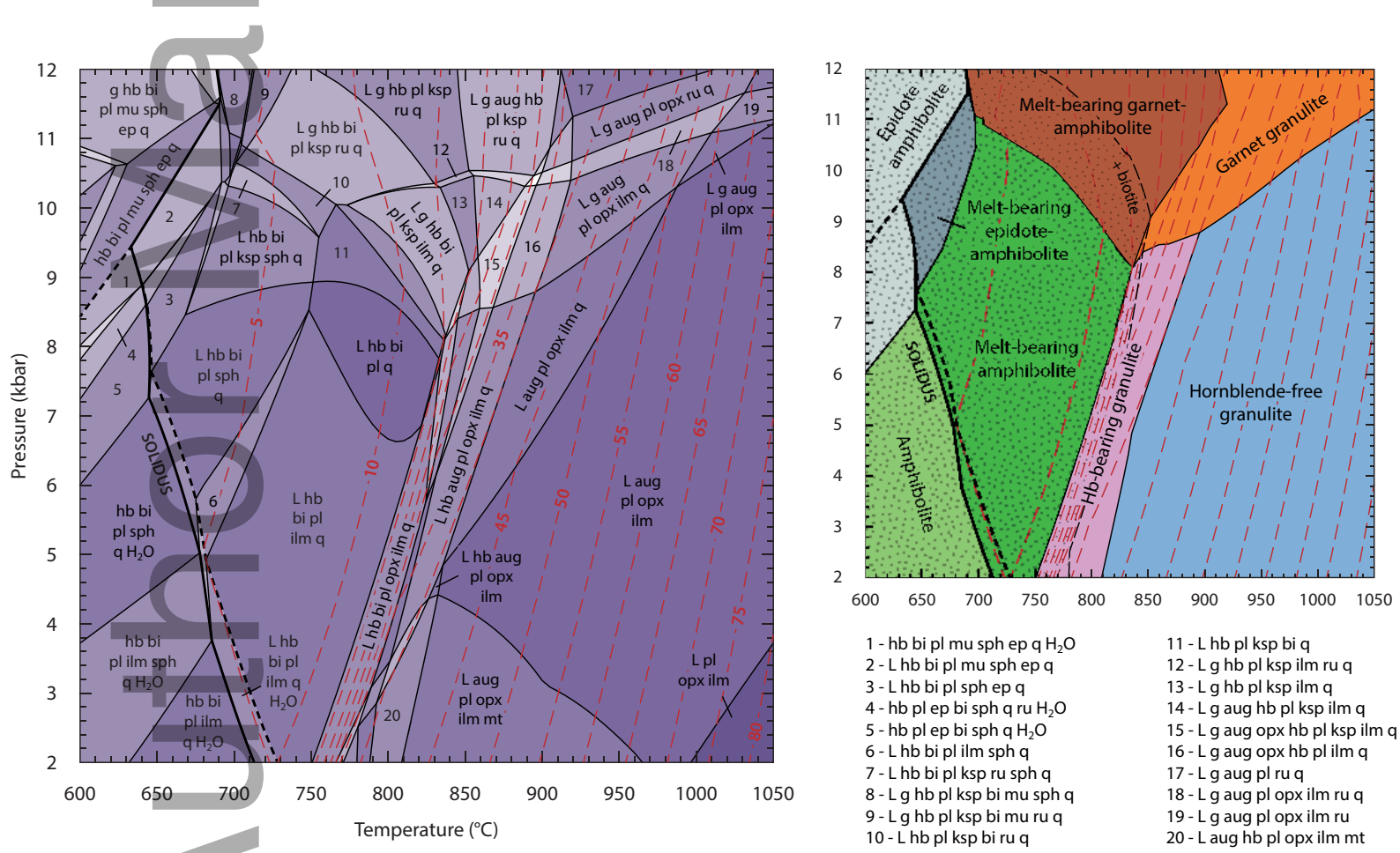

Figure 2: 


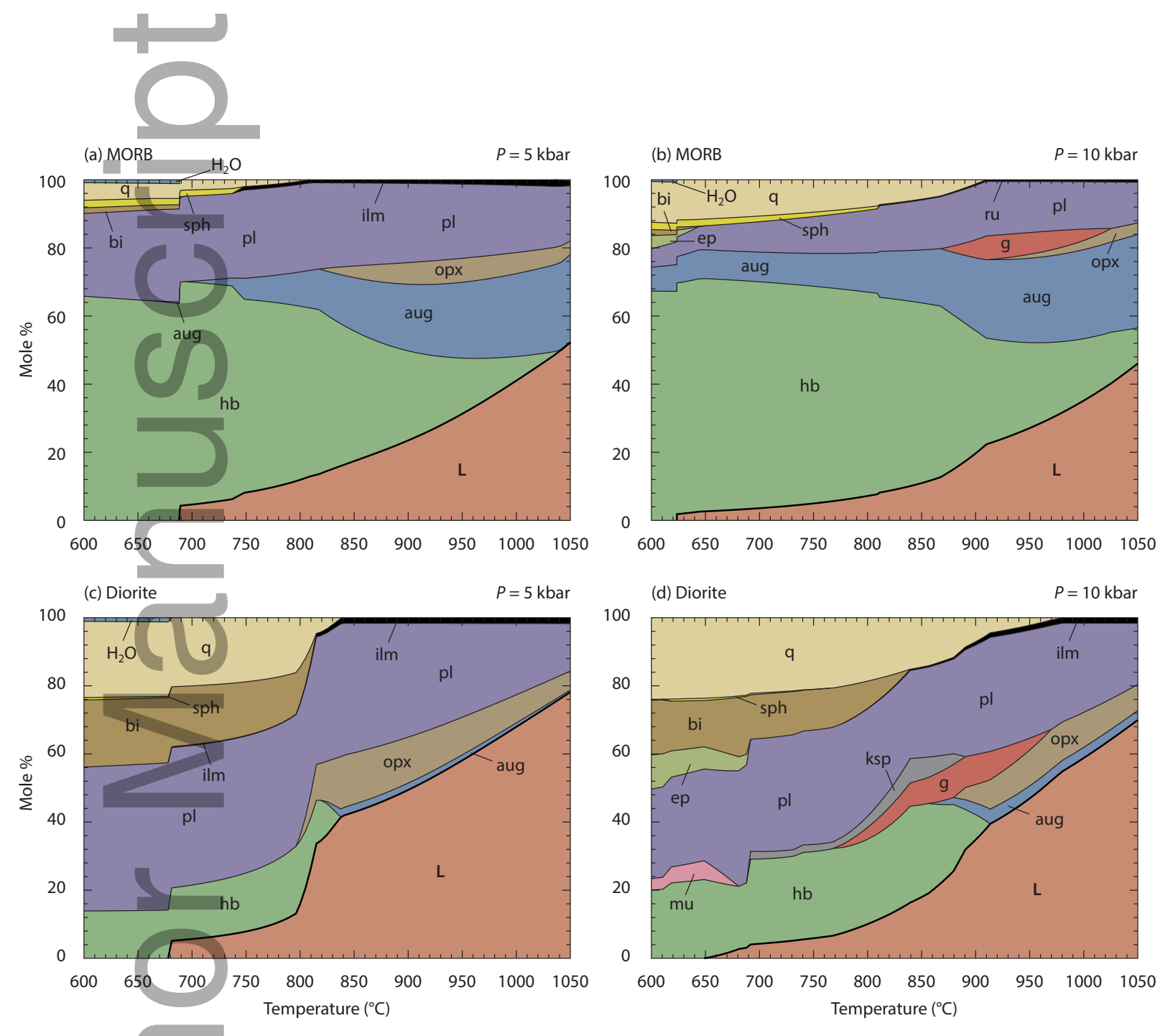

Figure 3: 

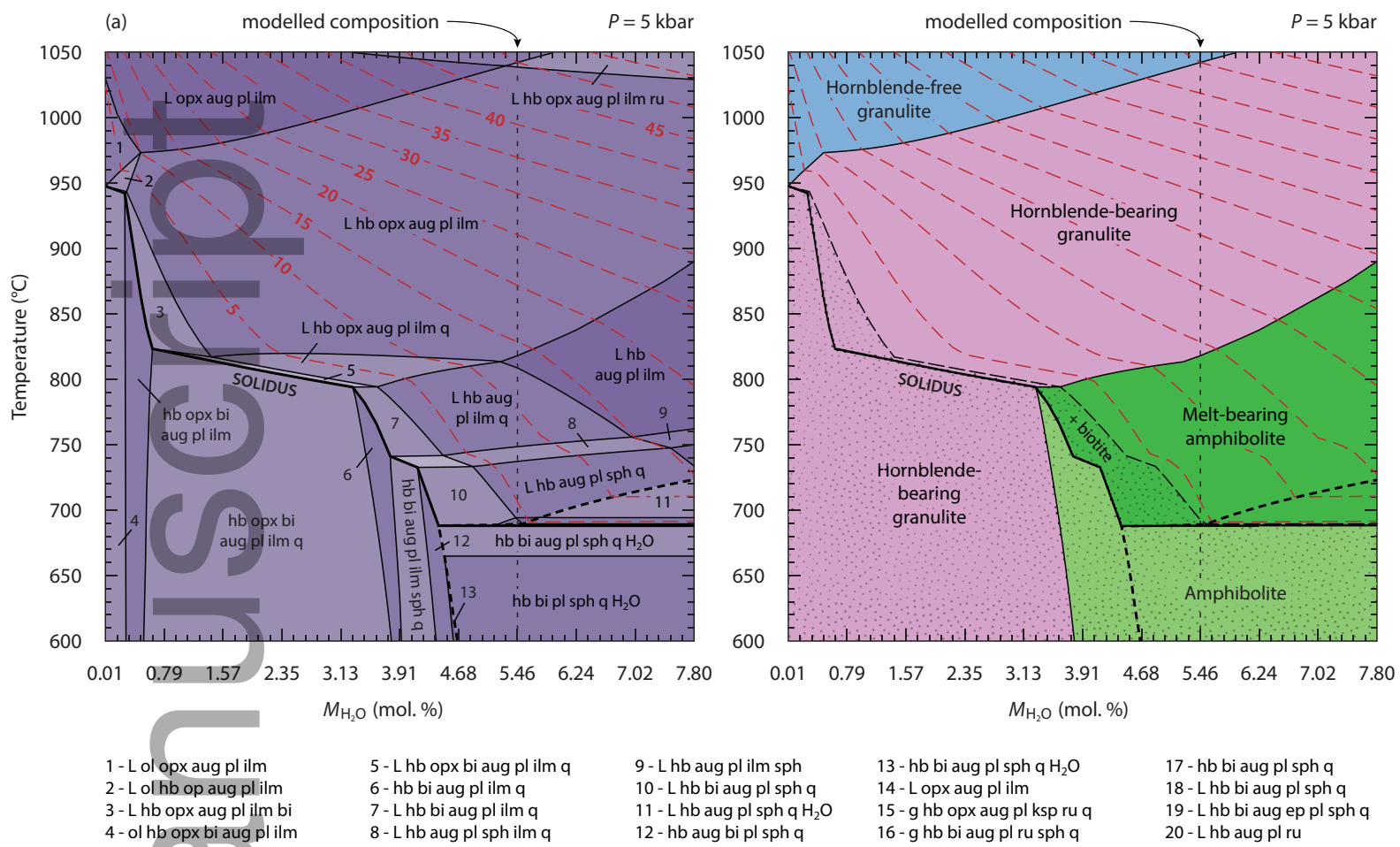

13 - hb bi aug pl sph q $\mathrm{H}_{2} \mathrm{O}$

$17-\mathrm{hb}$ bi aug pl sph q

18 - $\mathrm{Lhb}$ bi aug pl sph q

15 - g hb opx aug pl ksp ru q $\quad 19-\mathrm{L}$ hb bi aug ep pl sph q

4 - ol hbopx biaug plilm

12 - hb aug bi pl sph q

16 - ghb bi aug plru sph

$20-\mathrm{Lhb}$ aug $\mathrm{pl} \mathrm{ru}$

(b) modelled composition $P=10 \mathrm{kbar}$
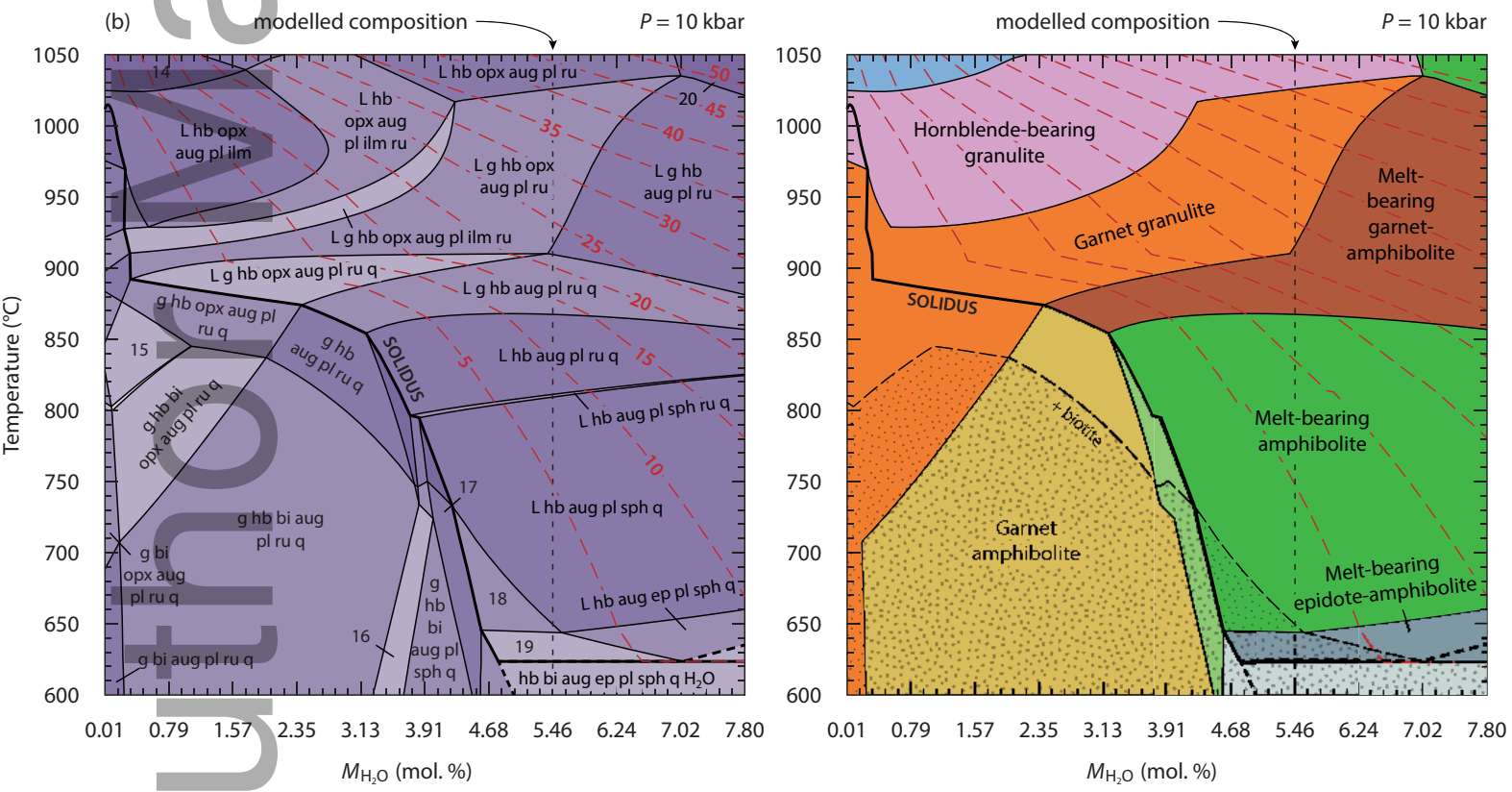

Figure 4: 


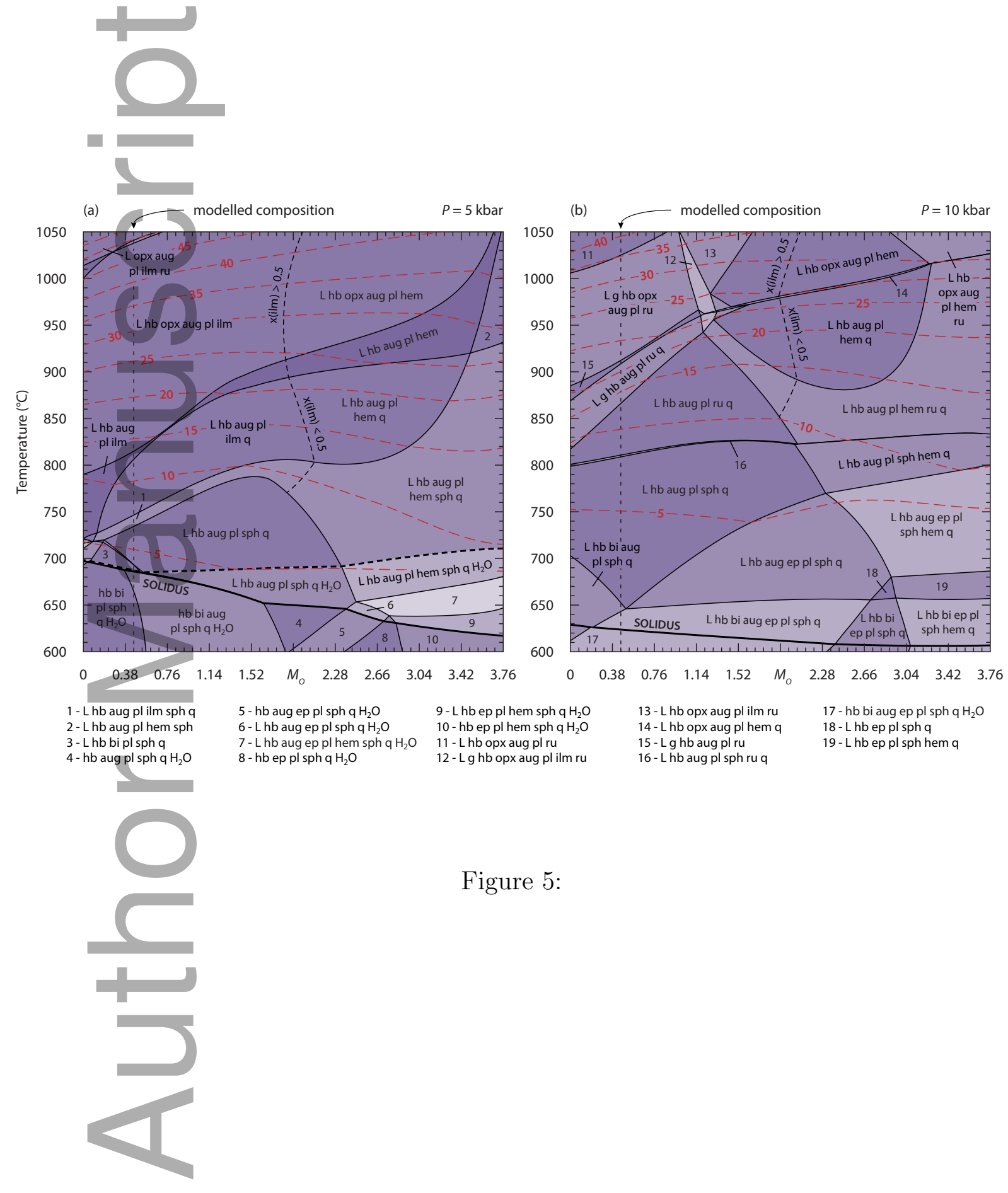




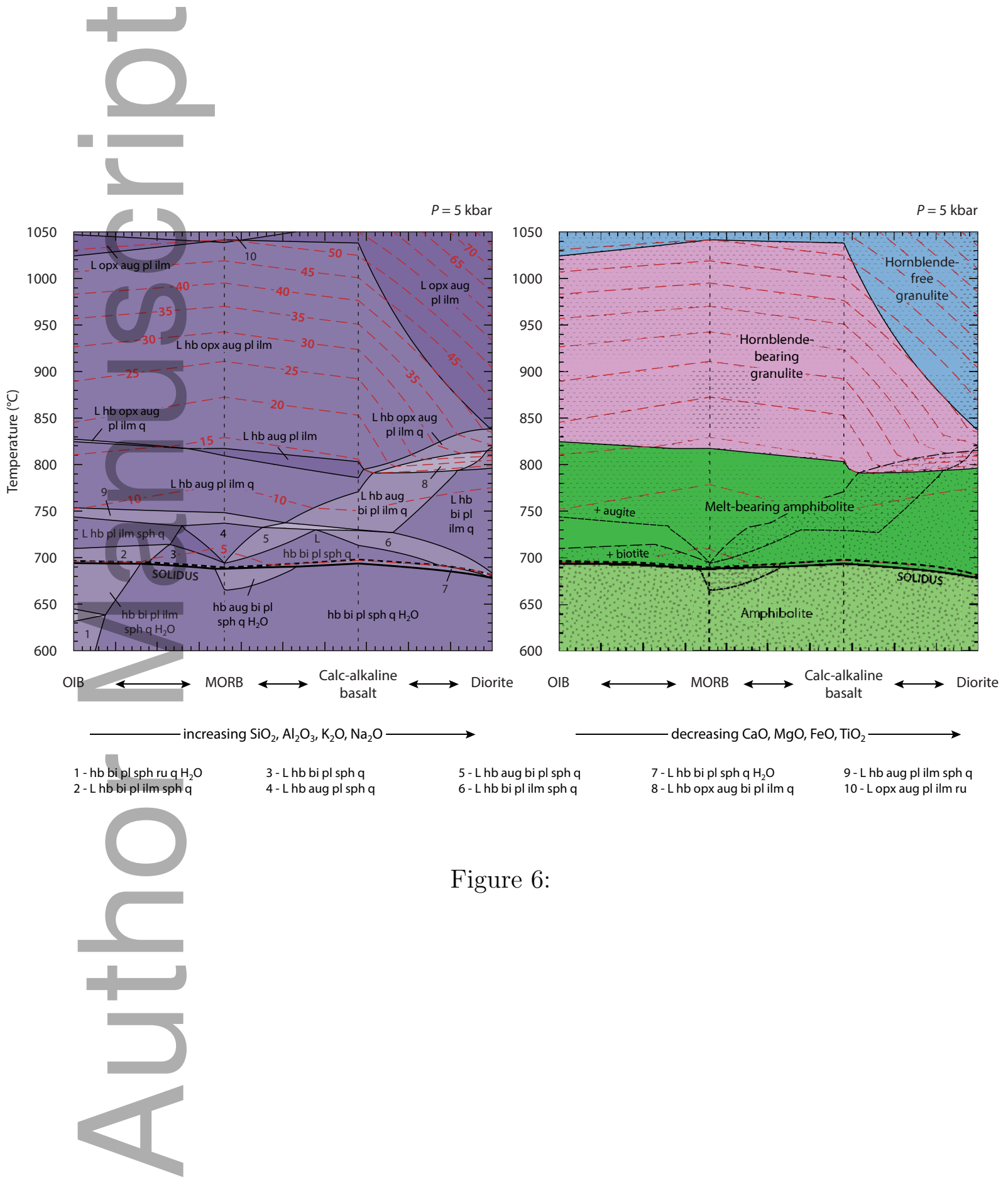




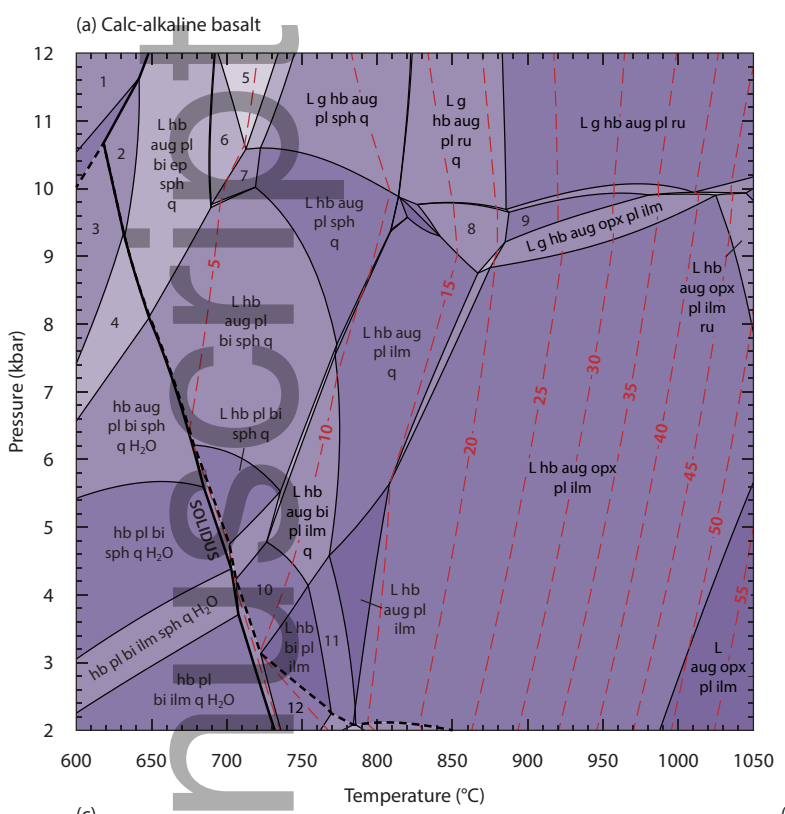

(b) Ocean island basalt
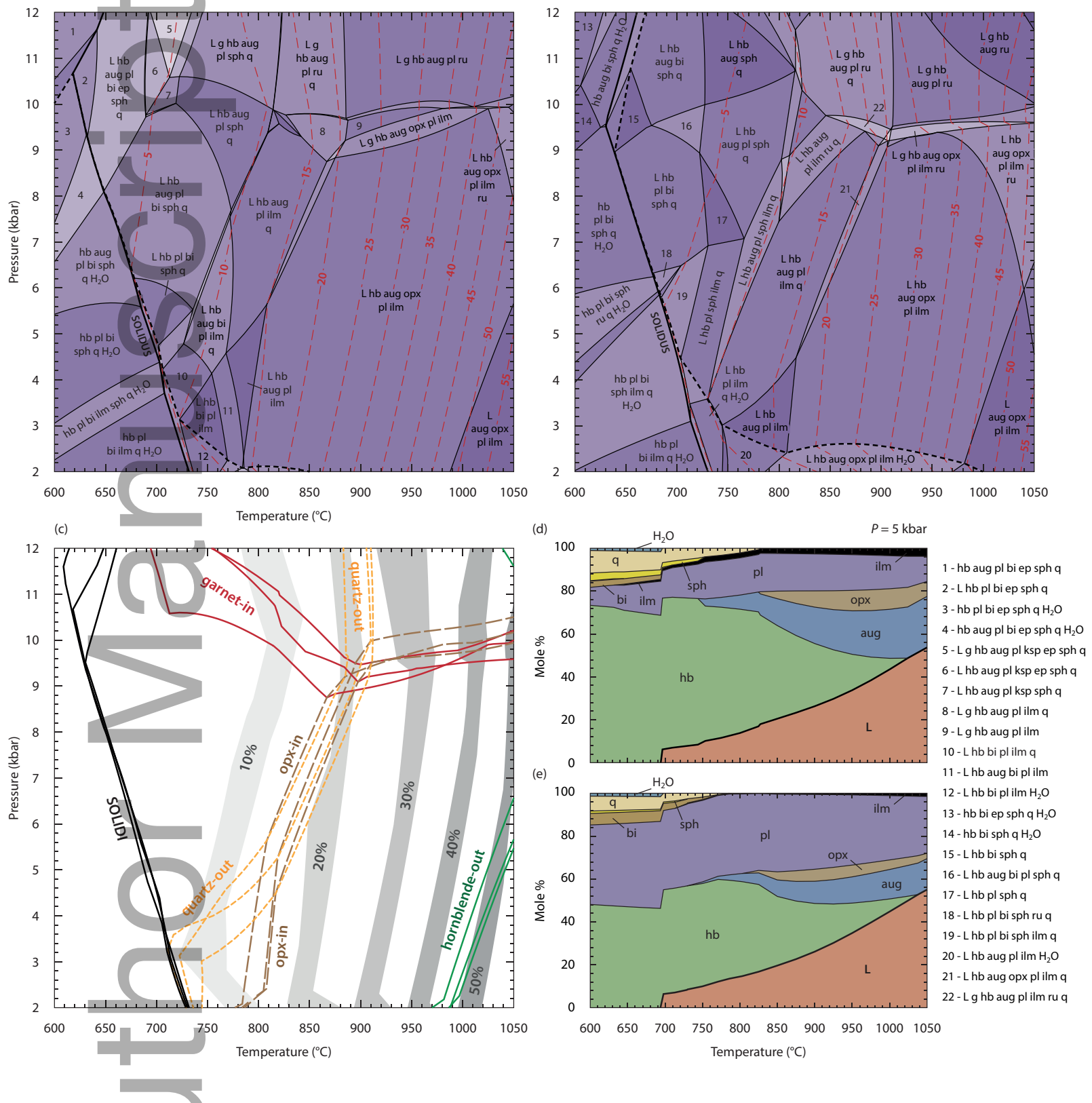

Figure 7: 
(a) MORB

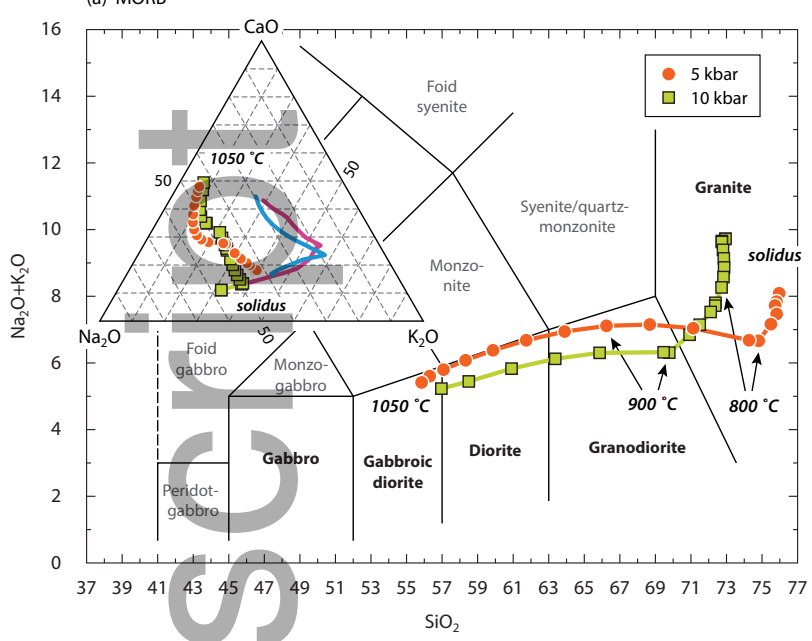

(b) Diorite

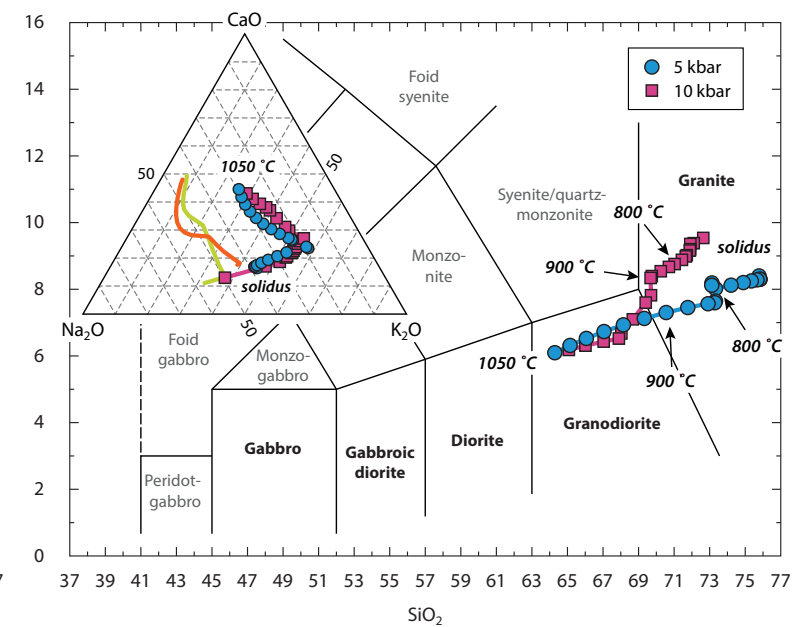

Figure 8:

(a)

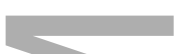

(a)

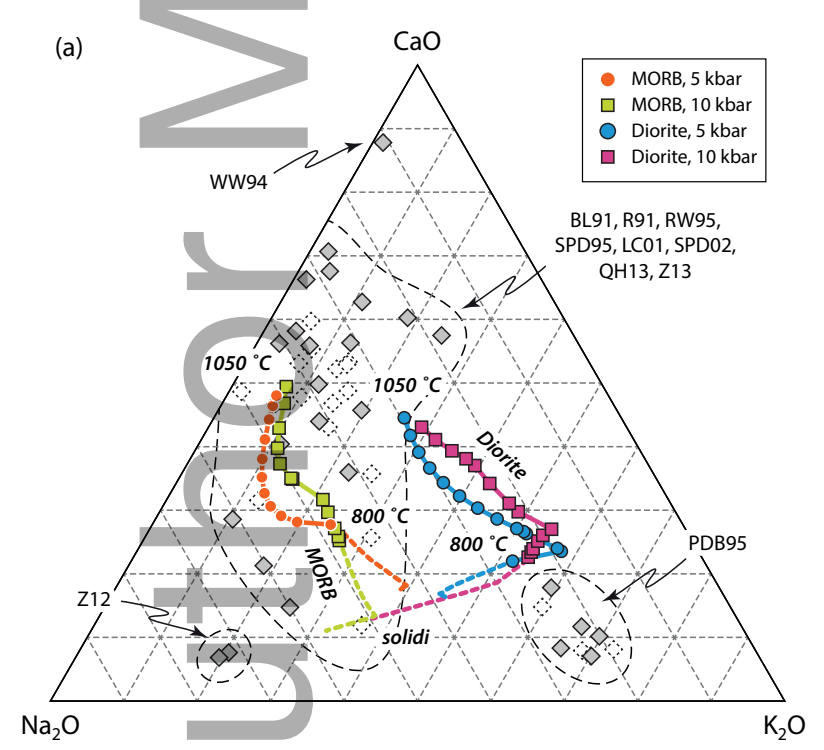

$\mathrm{K}_{2} \mathrm{O}$

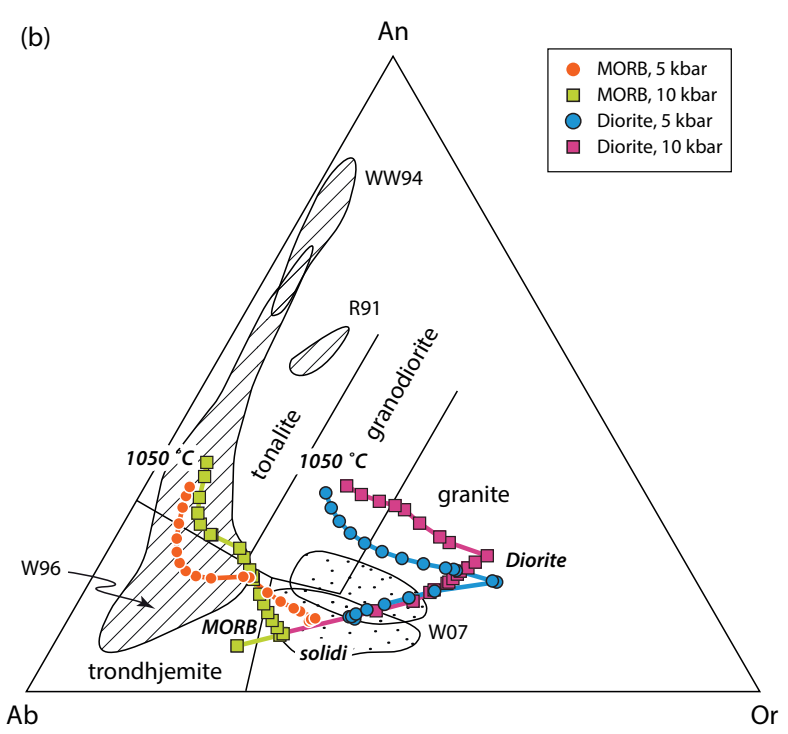

Figure 9: 

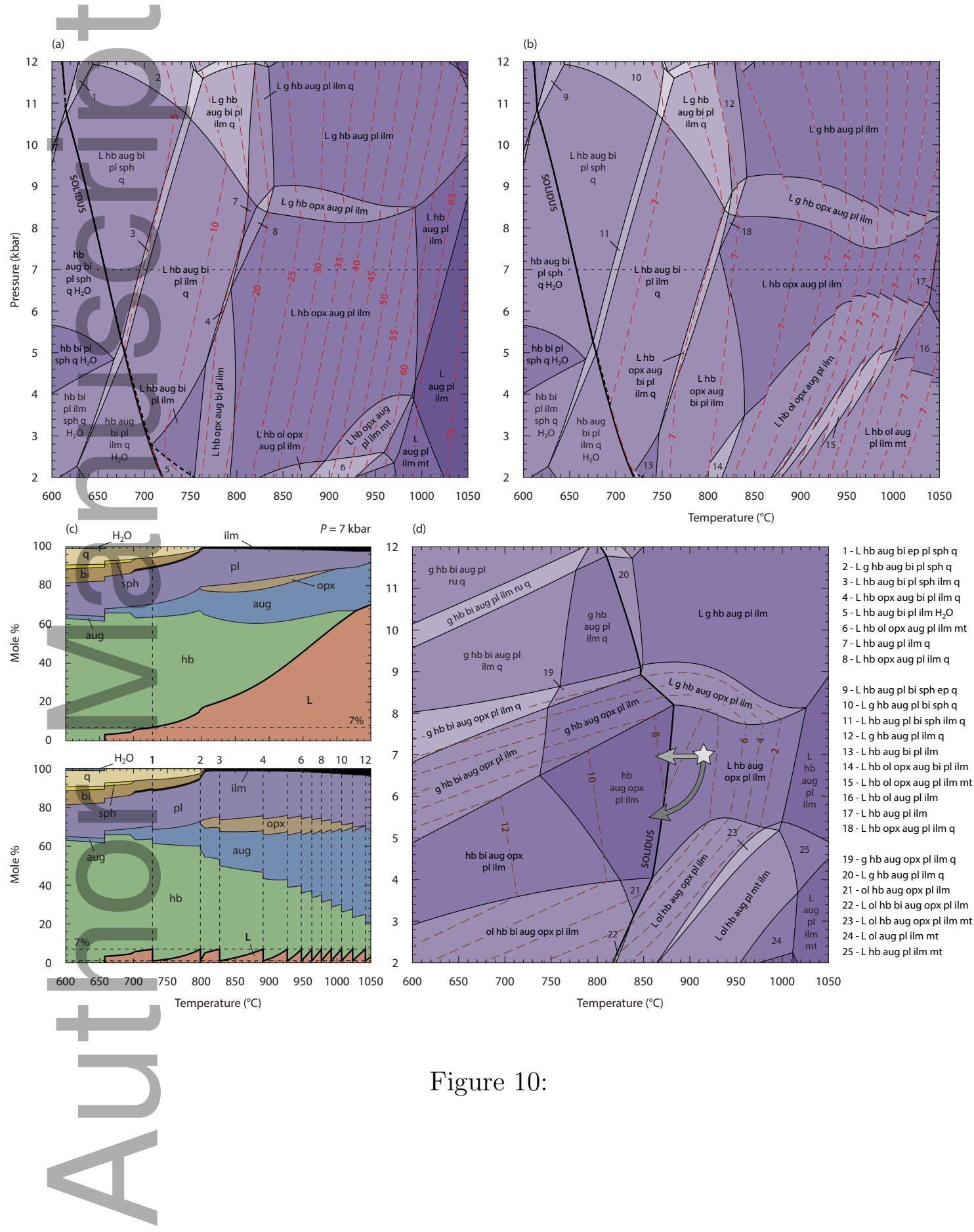

Figure 10: 


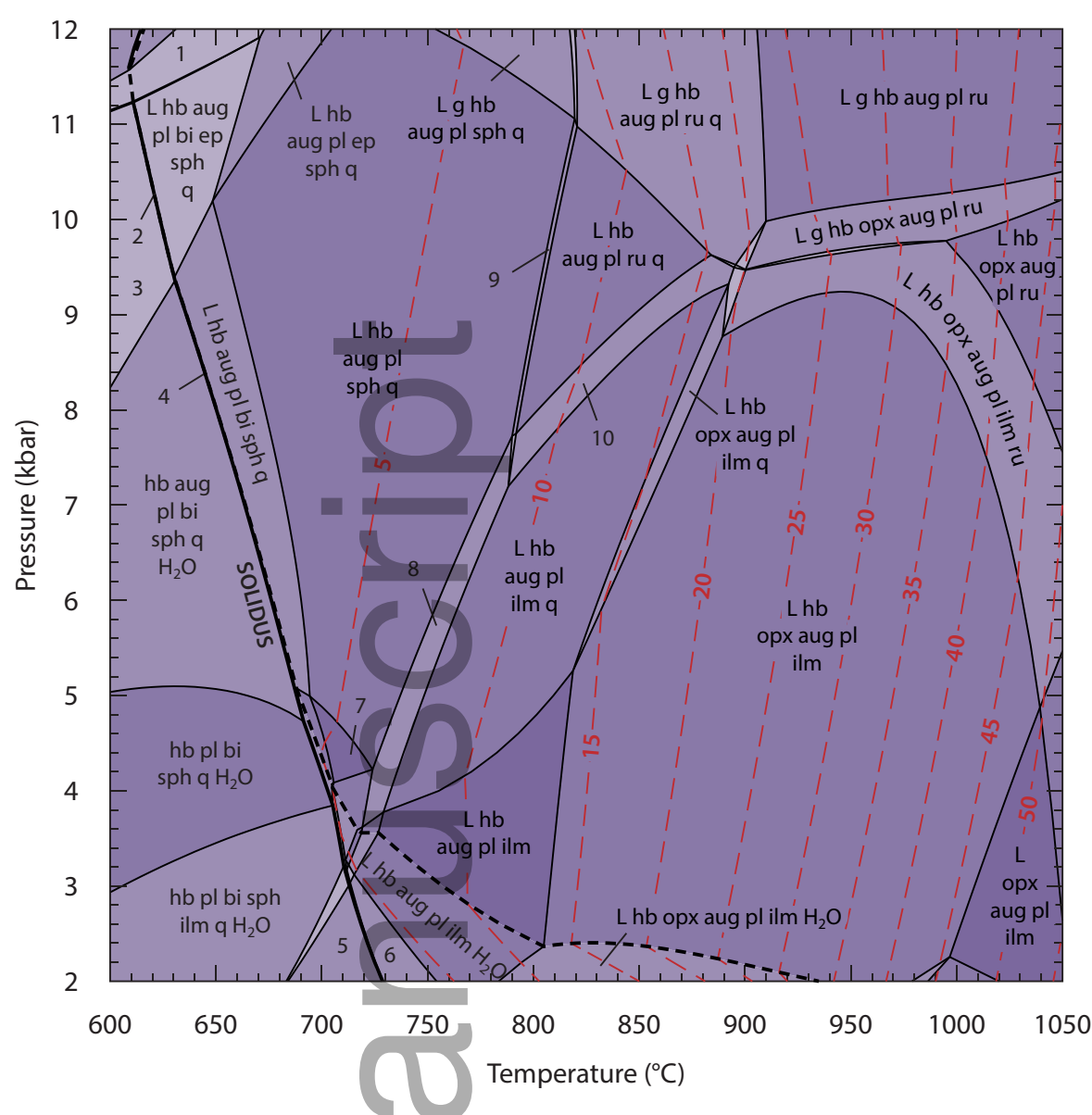

jmg_12212_f1.eps

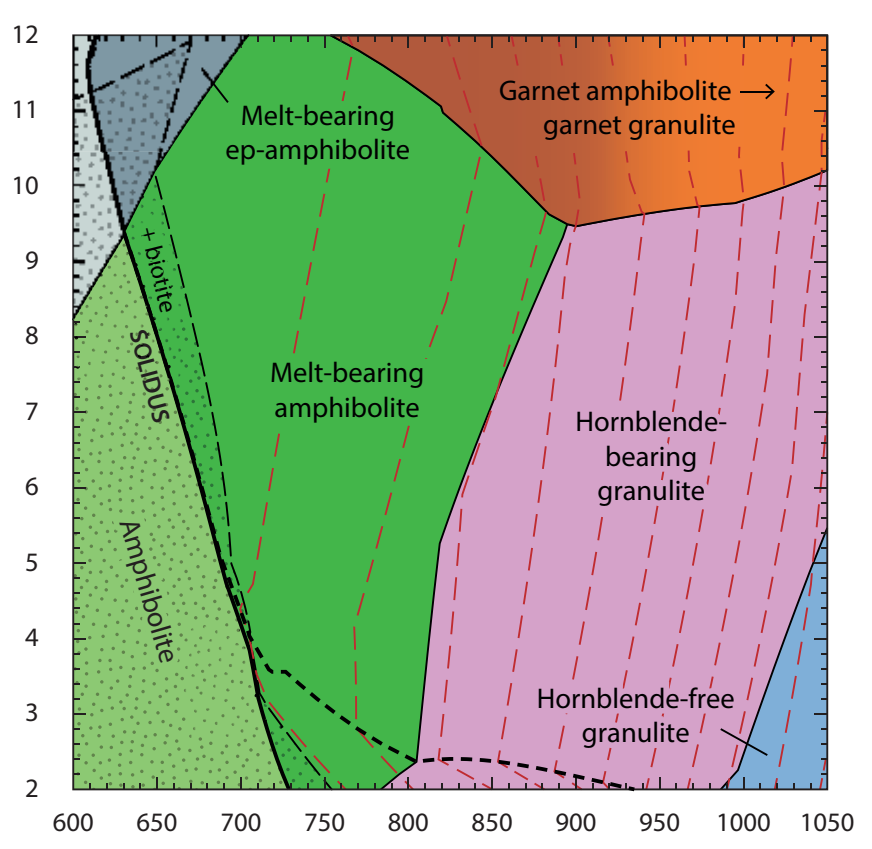

1 - L hb aug ep pl mu sph q 2 - $\mathrm{L}$ hb aug pl bi ep sph q $\mathrm{H}_{2} \mathrm{O}$ 3 - hb aug pl bi ep sph q $\mathrm{H}_{2} \mathrm{O}$

4 - $\mathrm{L}$ hb aug pl bi sph q $\mathrm{H}_{2} \mathrm{O}$

5 - $\mathrm{hb}$ aug pl bi sph ilm $\mathrm{H}_{2} \mathrm{O}$
6 - $\mathrm{L}$ hb bi aug pl ilm $\mathrm{H}_{2} \mathrm{O}$ 7 - L hb pl sph q

8 - L hb aug pl ilm sph q 9 - L hb aug pl ru sph q 10 - L hb aug pl ru ilm q

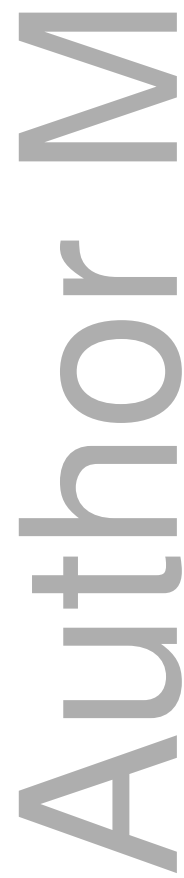



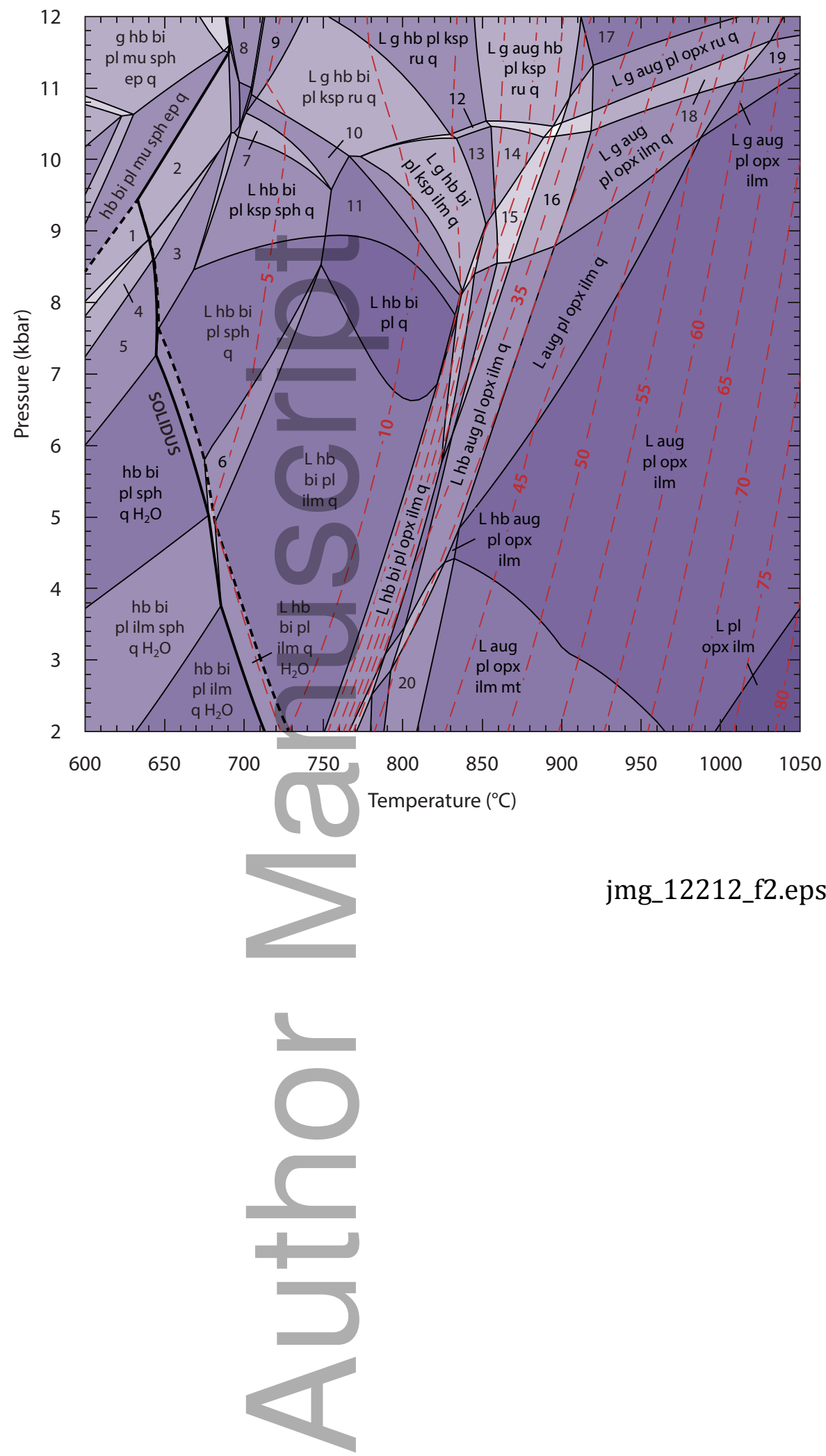

jmg_12212_f2.eps

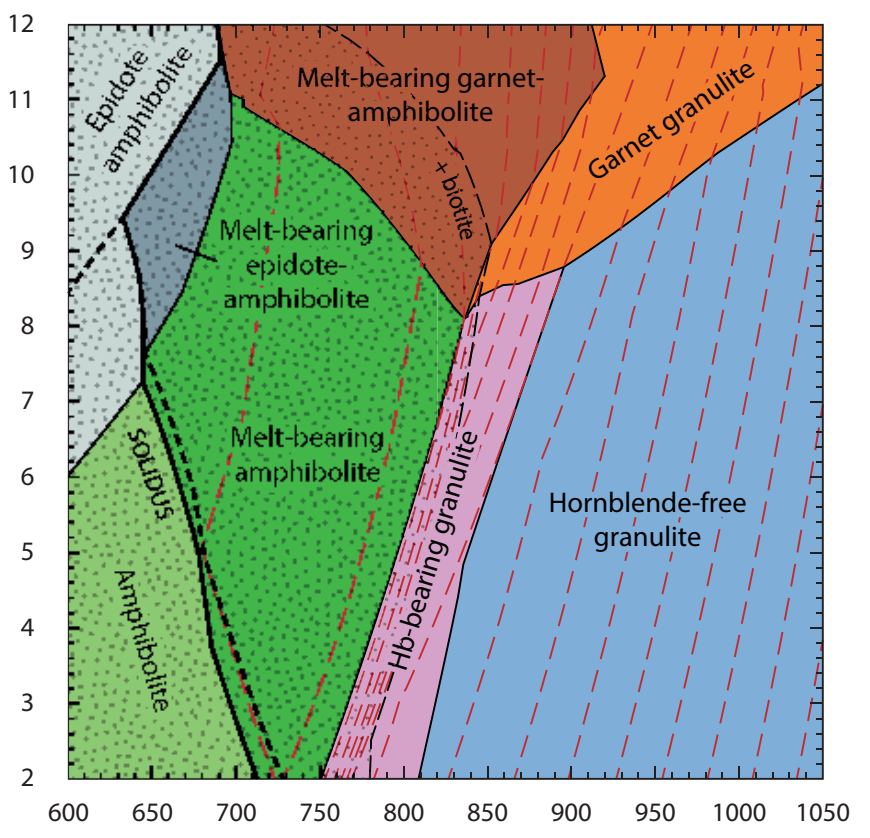

1 - hb bi pl mu sph ep q $\mathrm{H}_{2} \mathrm{O}$ 2 - L hb bi pl mu sph ep q

3 - L hb bi pl sph ep q

4 - hb pl ep bi sph q ru $\mathrm{H}_{2} \mathrm{O}$

5 - hb pl ep bi sph q $\mathrm{H}_{2} \mathrm{O}$

6 - L hb bi pl ilm sph q

7 - L hb bi pl ksp ru sph q

8 - L g hb pl ksp bi mu sph q

9 - L g hb pl ksp bi mu ru q

10 - L hb pl ksp bi ru q
11 - L hb pl ksp bi q

12 - L g hb pl ksp ilm ru q

13 - L g hb pl ksp ilm q

14 - L g aug hb pl ksp ilm q

15 - L g aug opx hb pl ksp ilm a 16 - L g aug opx hb pl ilm q $17-\mathrm{Lg}$ aug $\mathrm{pl}$ ru $\mathrm{q}$

18 - $\mathrm{L} g$ aug pl opx ilm ru q 19 - L g aug pl opx ilm ru 20 - L aug hb pl opx ilm mt 


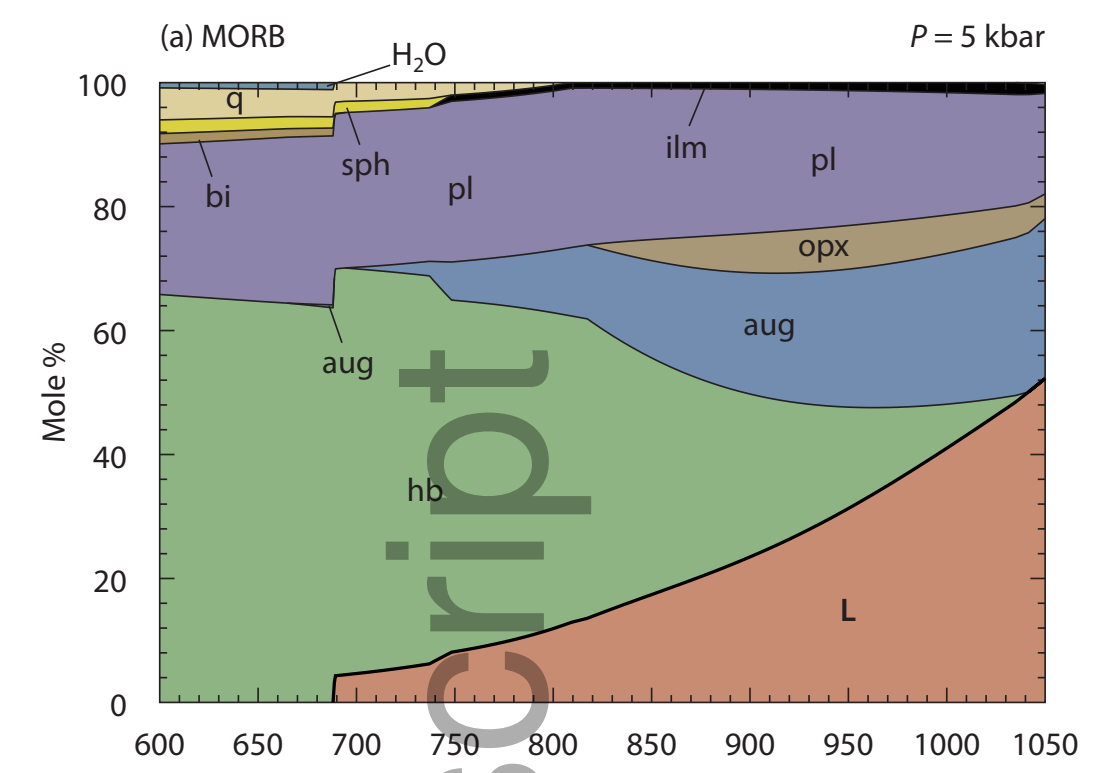

(b) MORB

$P=10 \mathrm{kbar}$

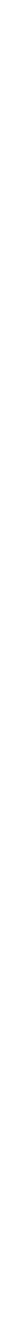



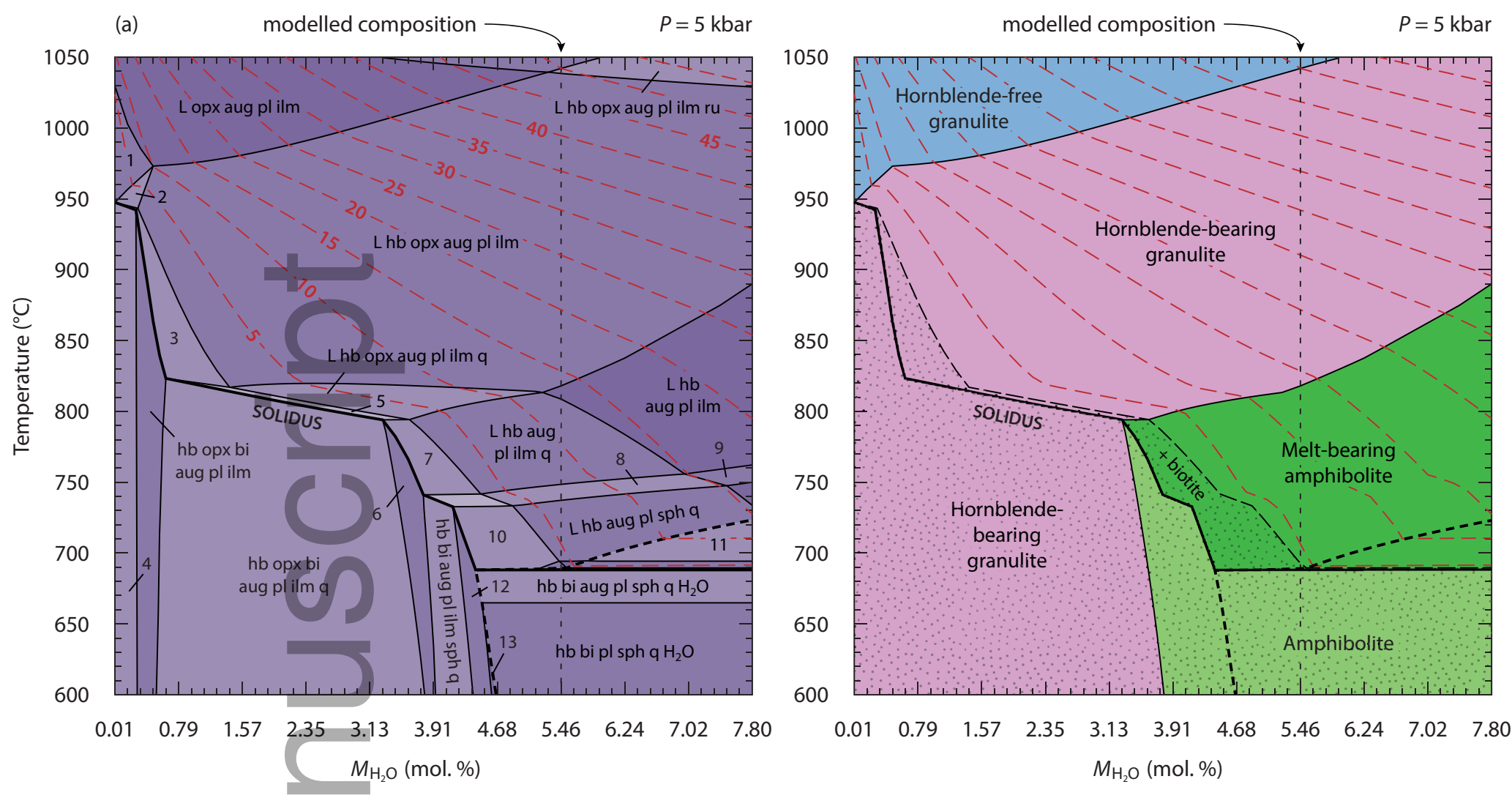

1 - L ol opx aug pl ilm 2 - L ol hb op aug pl ilm 3 - L hb opx aug pl ilm bi

4 - ol hb opx bi aug plilm
$5-\mathrm{L}$ hb opx bi aug pl ilm q 6 - $\mathrm{hb}$ bi aug $\mathrm{pl}$ ilm q

7 - L hb bi aug pl ilm q 8 - L hb aug pl sph ilm q
9 - L hb aug pl ilm sph 10 - L hb bi aug pl sph q

11 - $\mathrm{L}$ hb aug pl sph q $\mathrm{H}_{2} \mathrm{O}$

12 - hb aug bi pl sph q
13 - hb bi aug pl sph q $\mathrm{H}_{2} \mathrm{O}$

14 - L opx aug pl ilm

15 - g hb opx aug pl ksp ru q

16 - $\mathrm{g} \mathrm{hb}$ bi aug pl ru sph q
17 - hb bi aug pl sph q 18 - L hb bi aug pl sph q $19-\mathrm{L} \mathrm{hb}$ bi aug ep pl sph q 20 - $\mathrm{L} h \mathrm{hb}$ aug $\mathrm{pl} \mathrm{ru}$
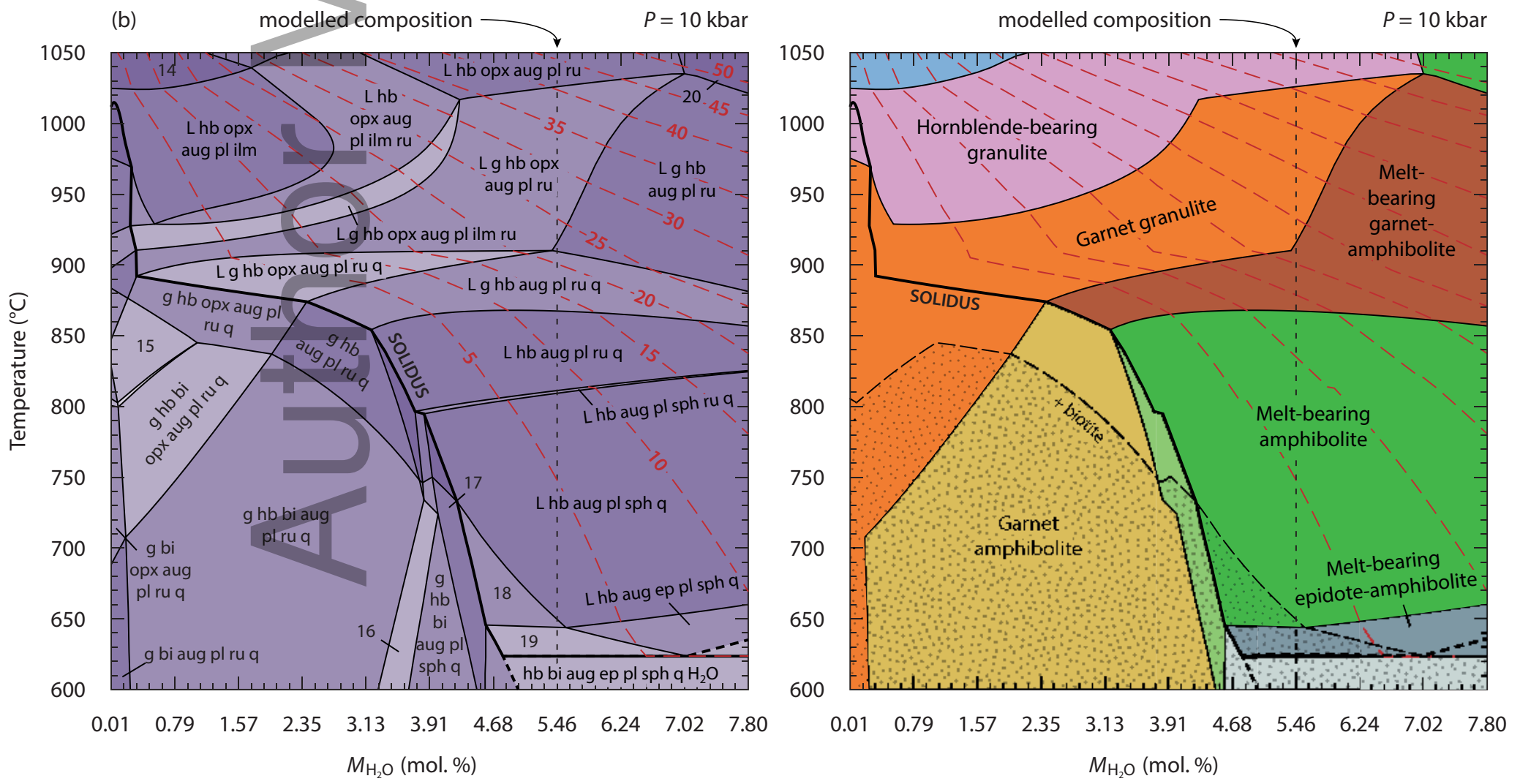

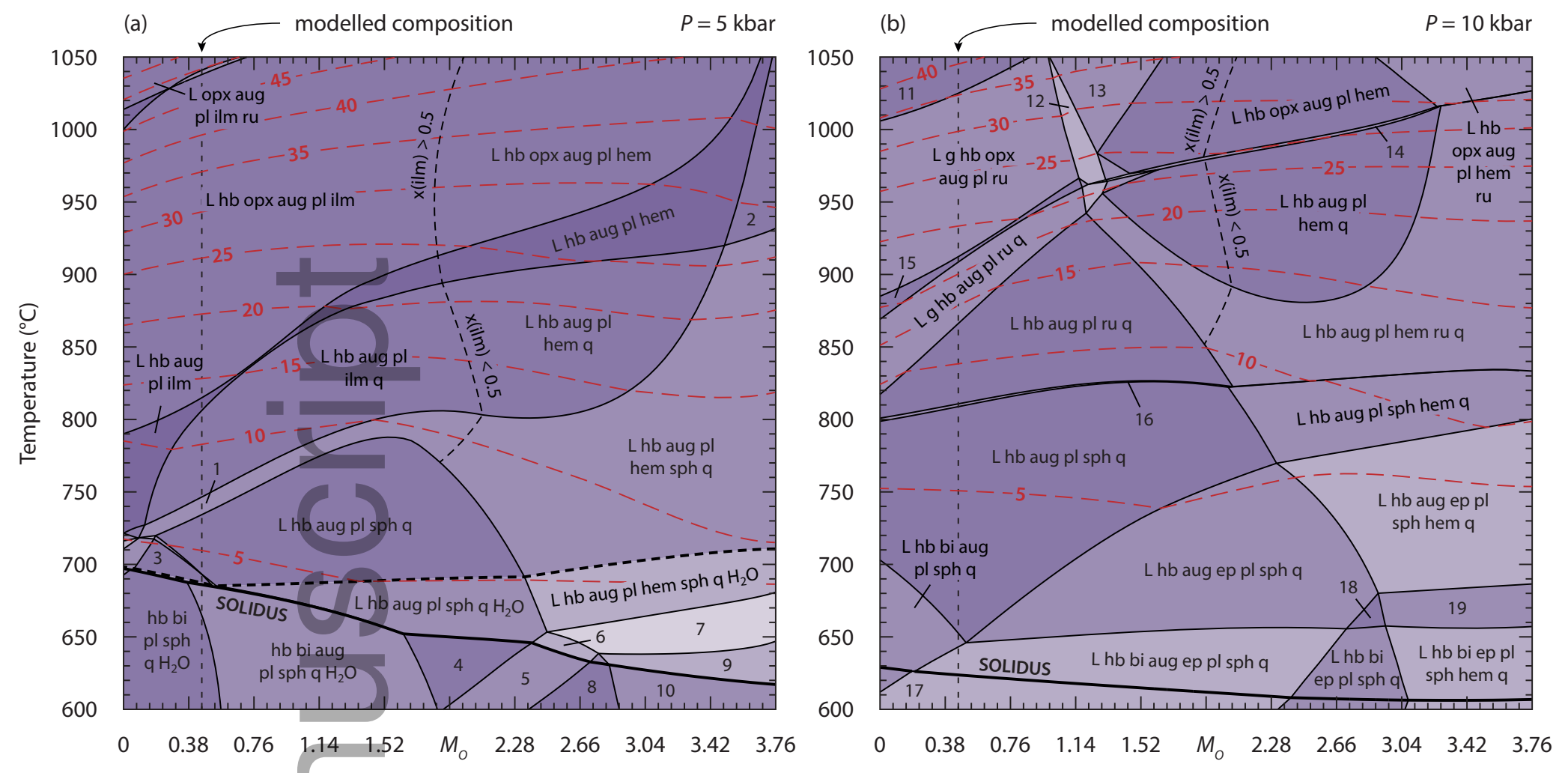

1 - $\mathrm{L}$ hb aug pl ilm sph q $\quad 5-\mathrm{hb}$ aug ep pl sph $\mathrm{q}_{2} \mathrm{O}$ 2 - L hb aug pl hem sph 6- $\mathrm{L}$ hb aug ep pl sph $\mathrm{q}_{2} \mathrm{O}$

9 - $\mathrm{L}$ hb ep pl hem sph q $\mathrm{H}_{2} \mathrm{O}$

$3-\mathrm{L} \mathrm{hb}$ bi pl sph q

4 - $\mathrm{hb}$ aug pl sph $\mathrm{q}_{2} \mathrm{O}$ 10 - hb ep pl hem sph q $\mathrm{H}_{2} \mathrm{O}$

$11-\mathrm{L} \mathrm{hb}$ opx aug pl ru 12 - L g hb opx aug pl ilm ru
13 - L hb opx aug pl ilm ru $14-L$ hb opx aug pl hem $q$ $15-\mathrm{L} g$ hb aug pl ru $16-\mathrm{L} h \mathrm{hb}$ aug $\mathrm{pl}$ sph ru q
17 - hb bi aug ep pl sph q $\mathrm{H}_{2} \mathrm{O}$ 18 - L hb ep pl sph q 19 - L hb ep pl sph hem q

jmg_12212_f5.eps

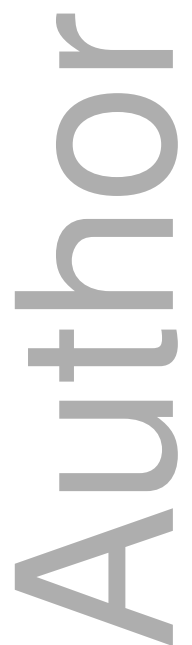




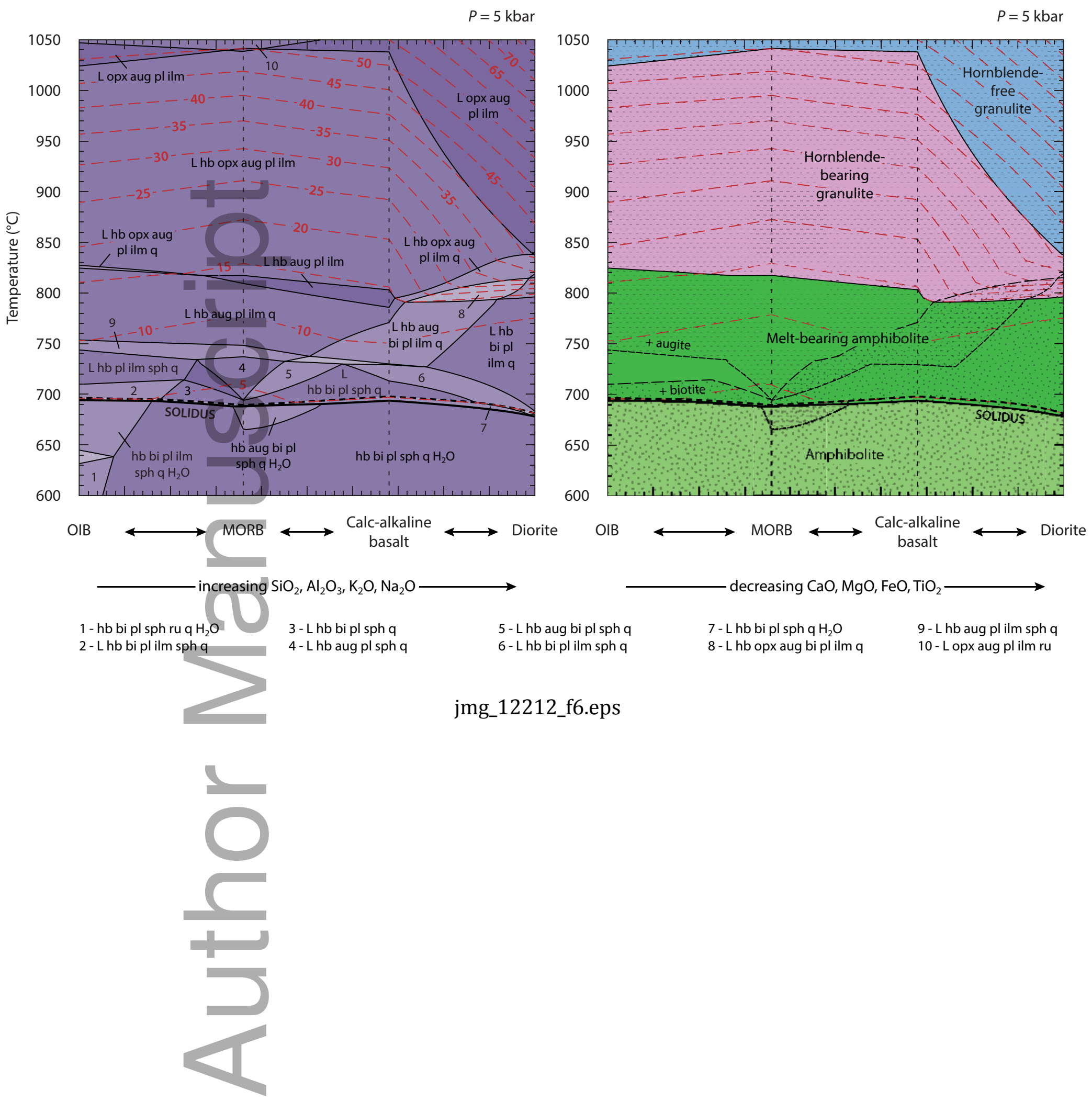


(a) Calc-alkaline basalt

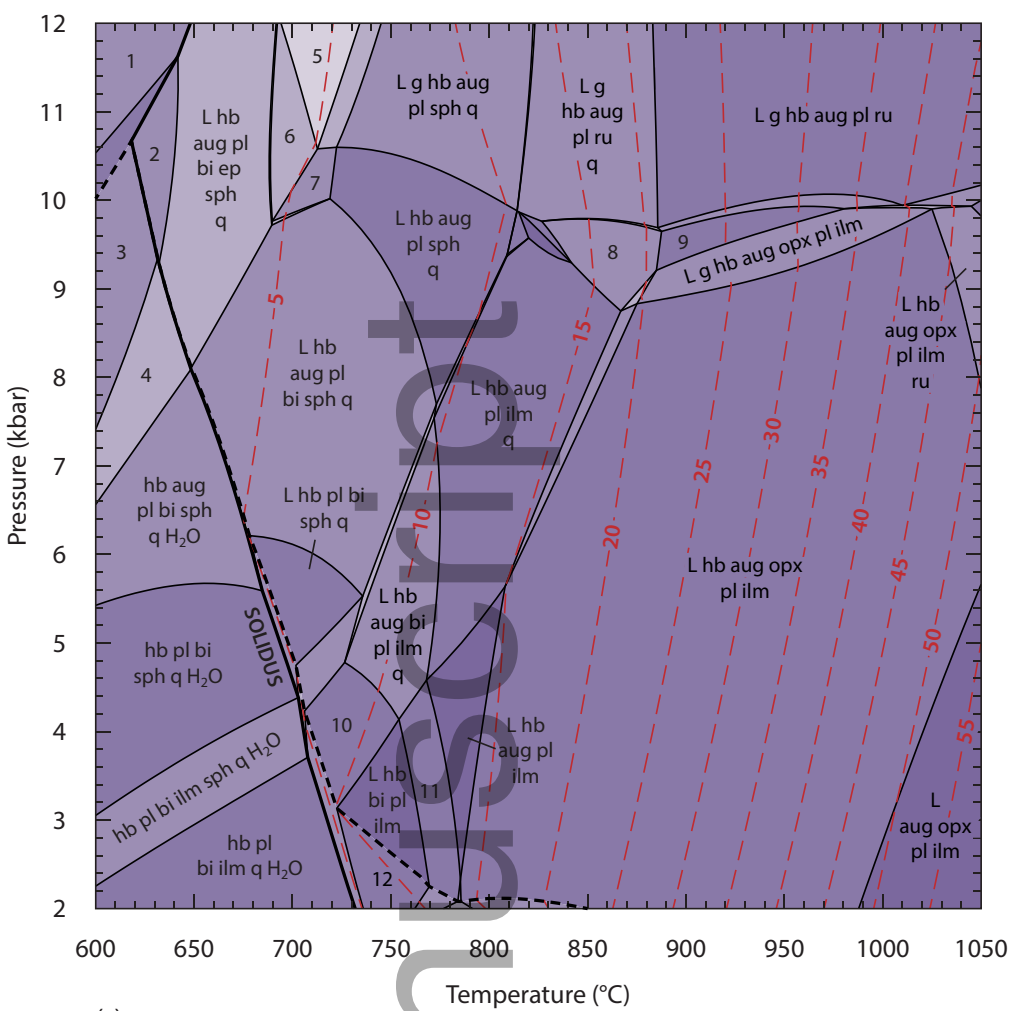

(c)

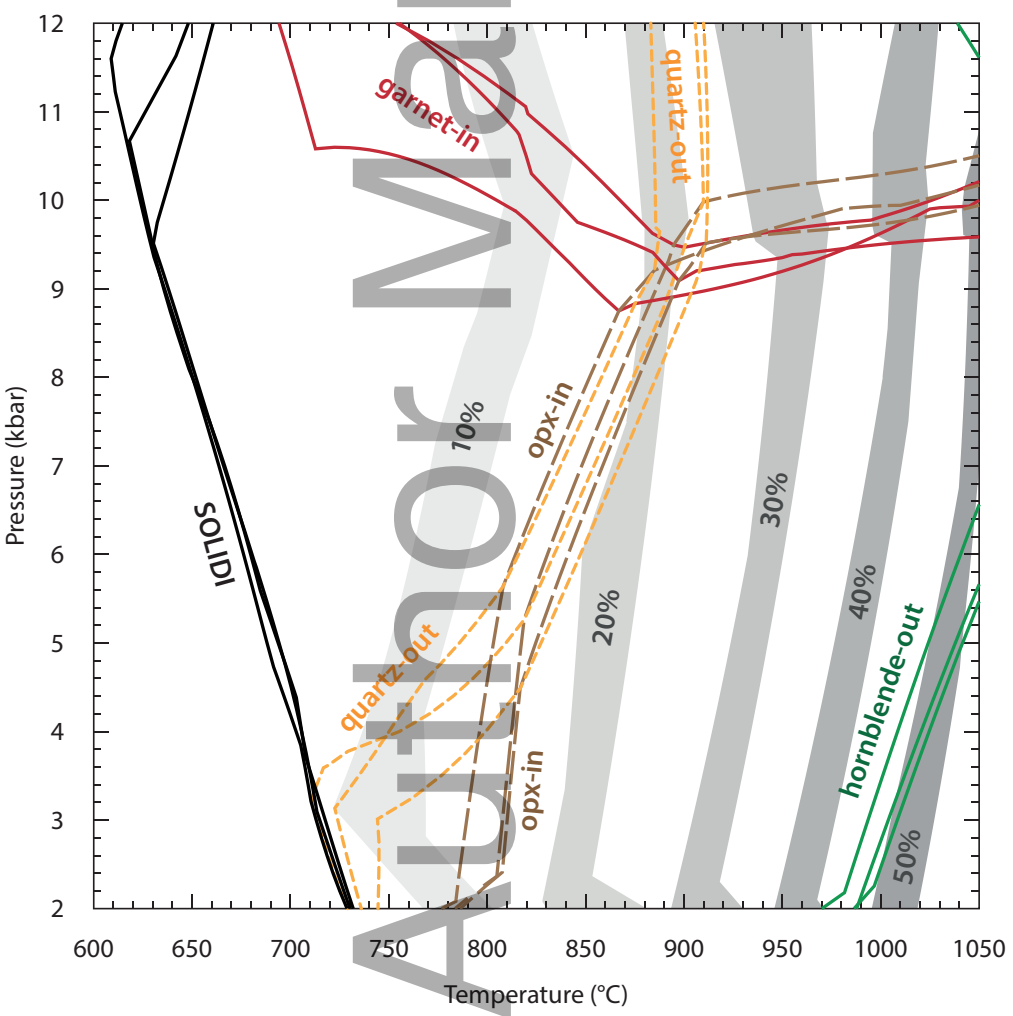

(b) Ocean island basalt

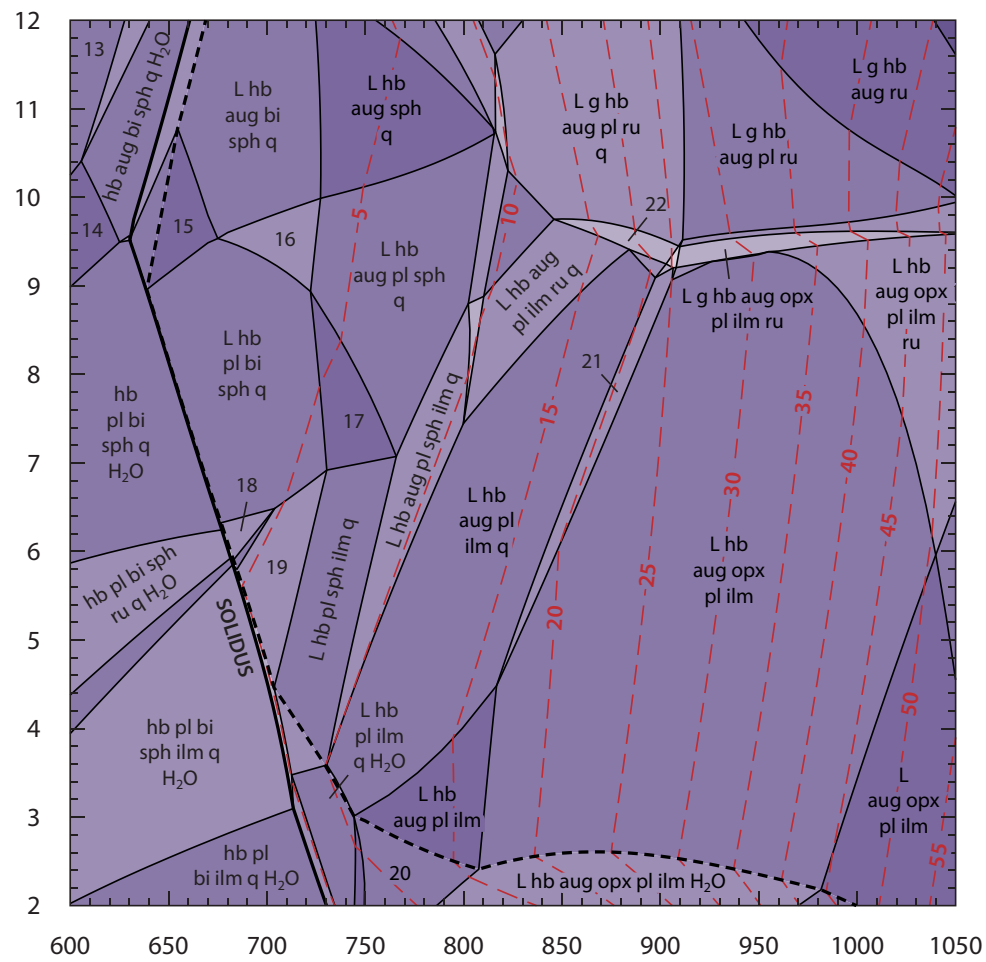

(d)

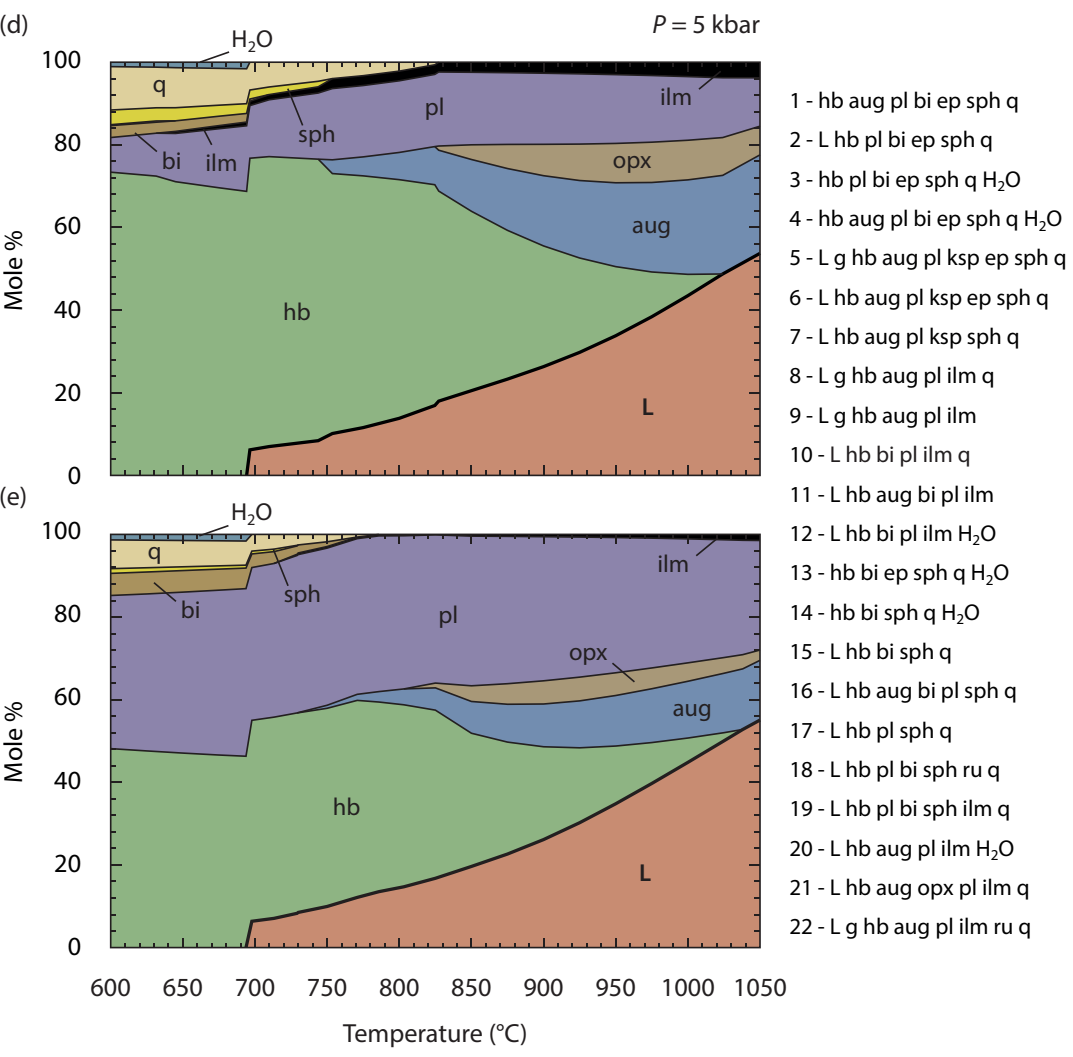

jmg_12212_f7.eps 
(a) MORB

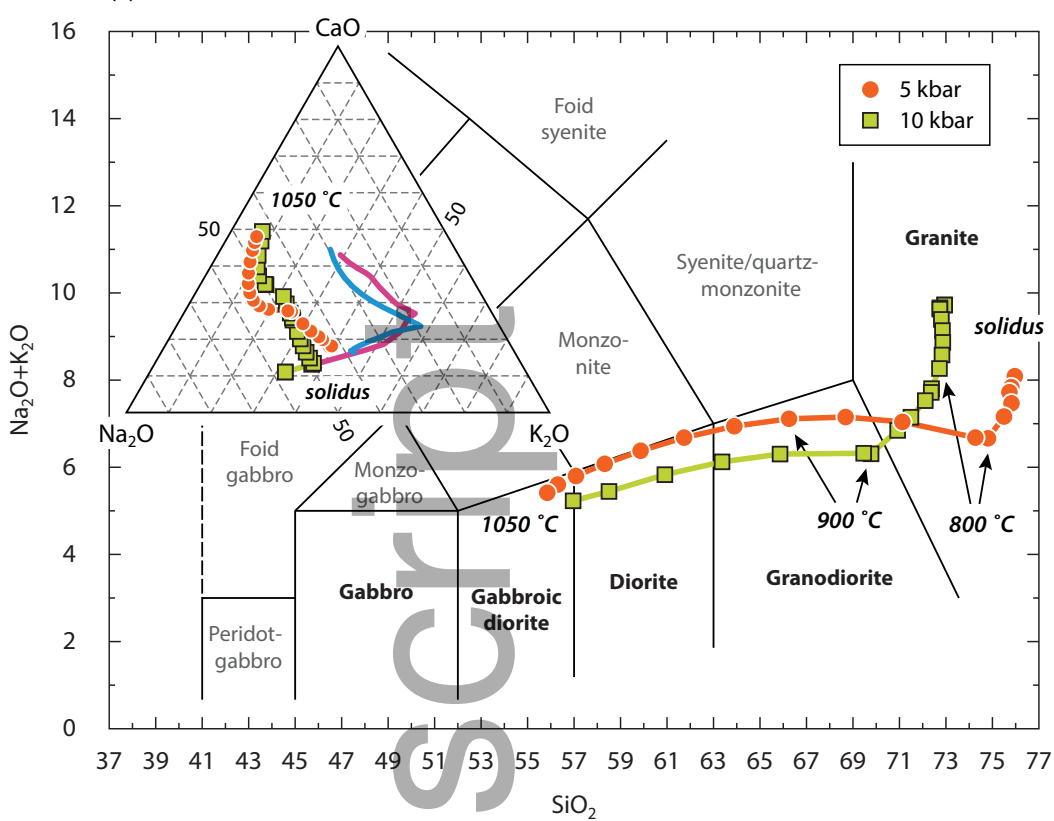

(b) Diorite

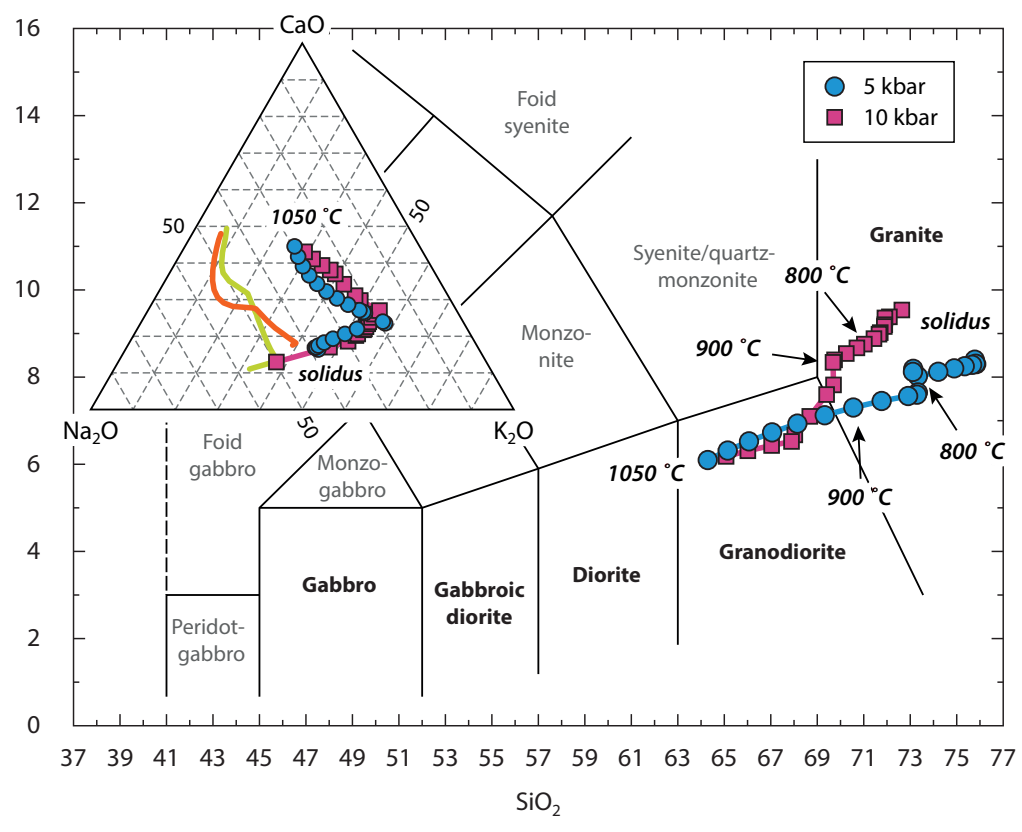

jmg_12212_f8.eps

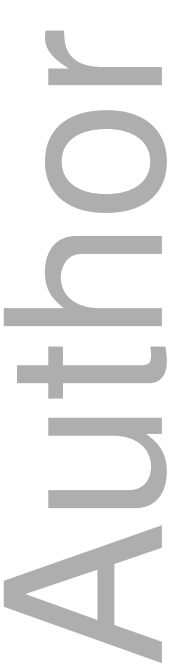


$\mathrm{Na}_{2} \mathrm{O}$ (a)

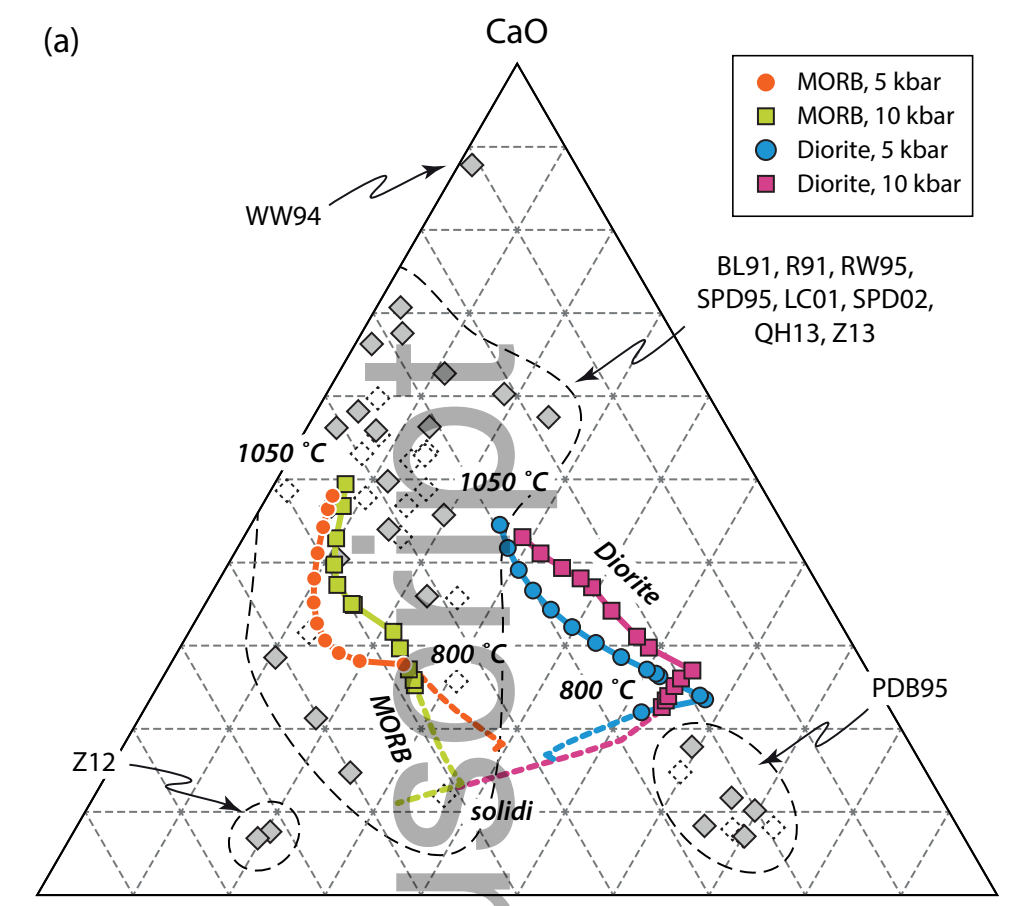

$\mathrm{CaO}$

(b)
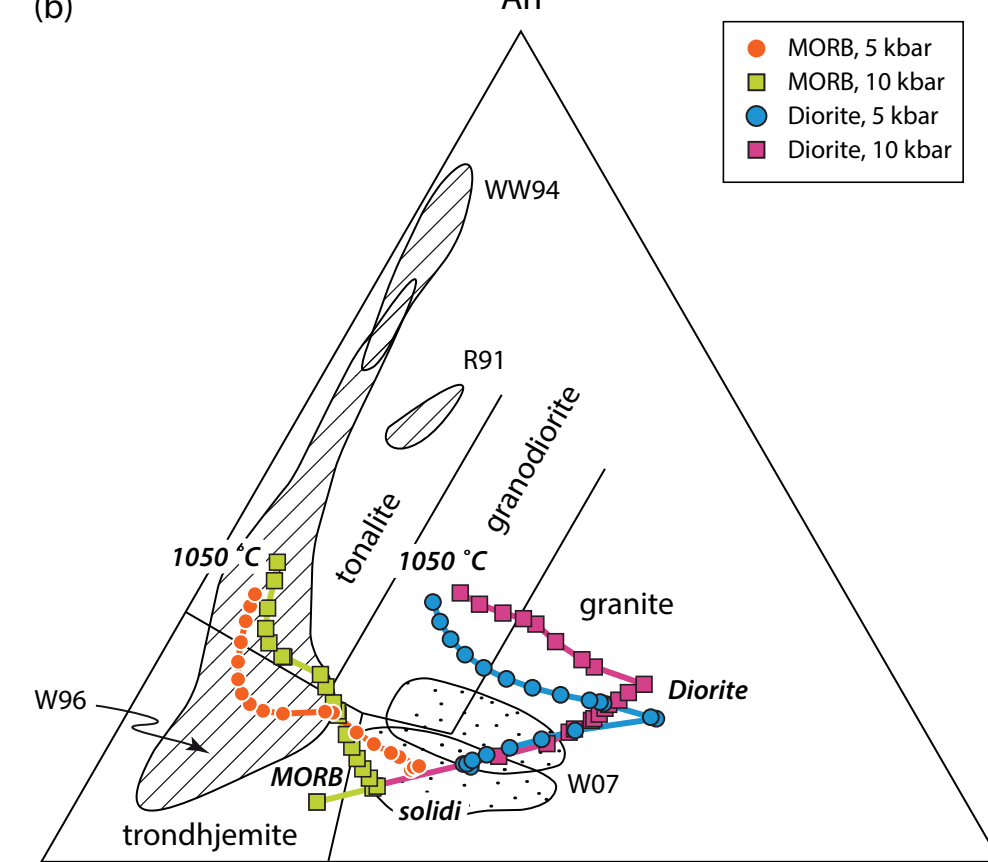

Ab

jmg_12212_f9.eps 
(a)

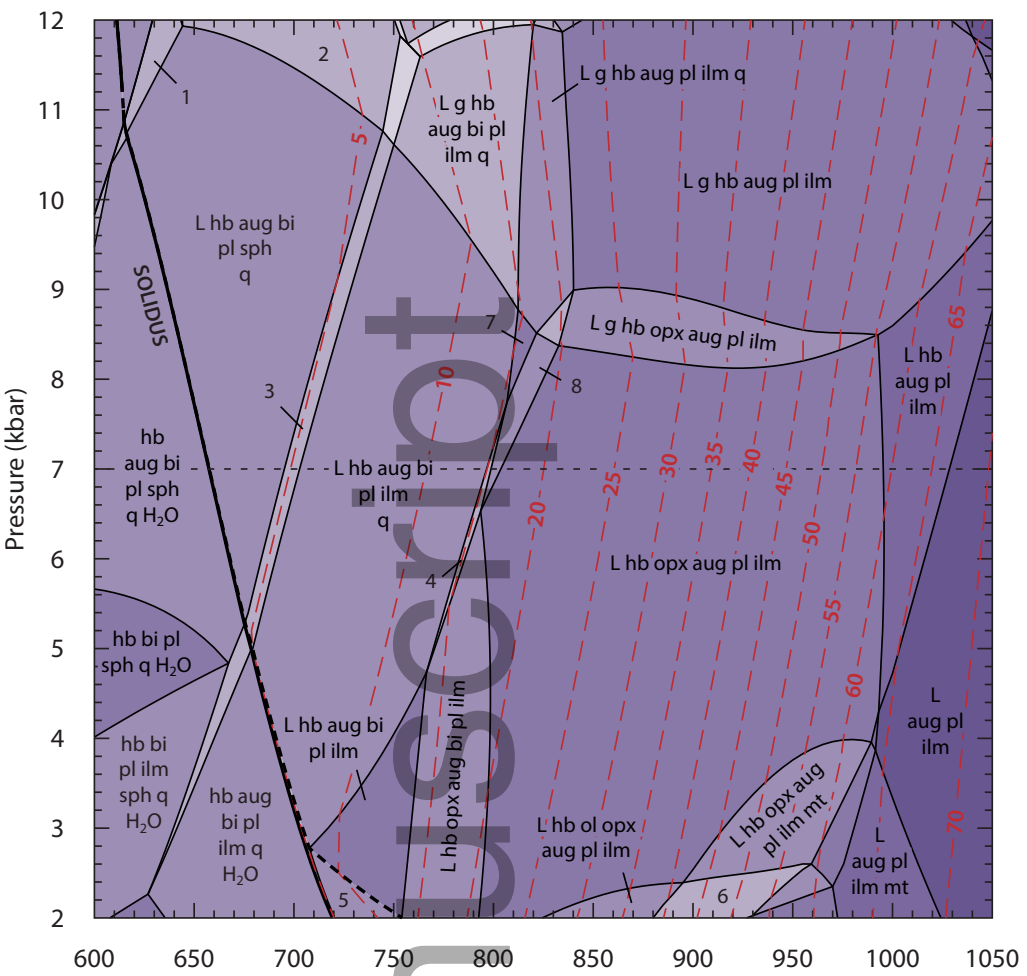

(b)

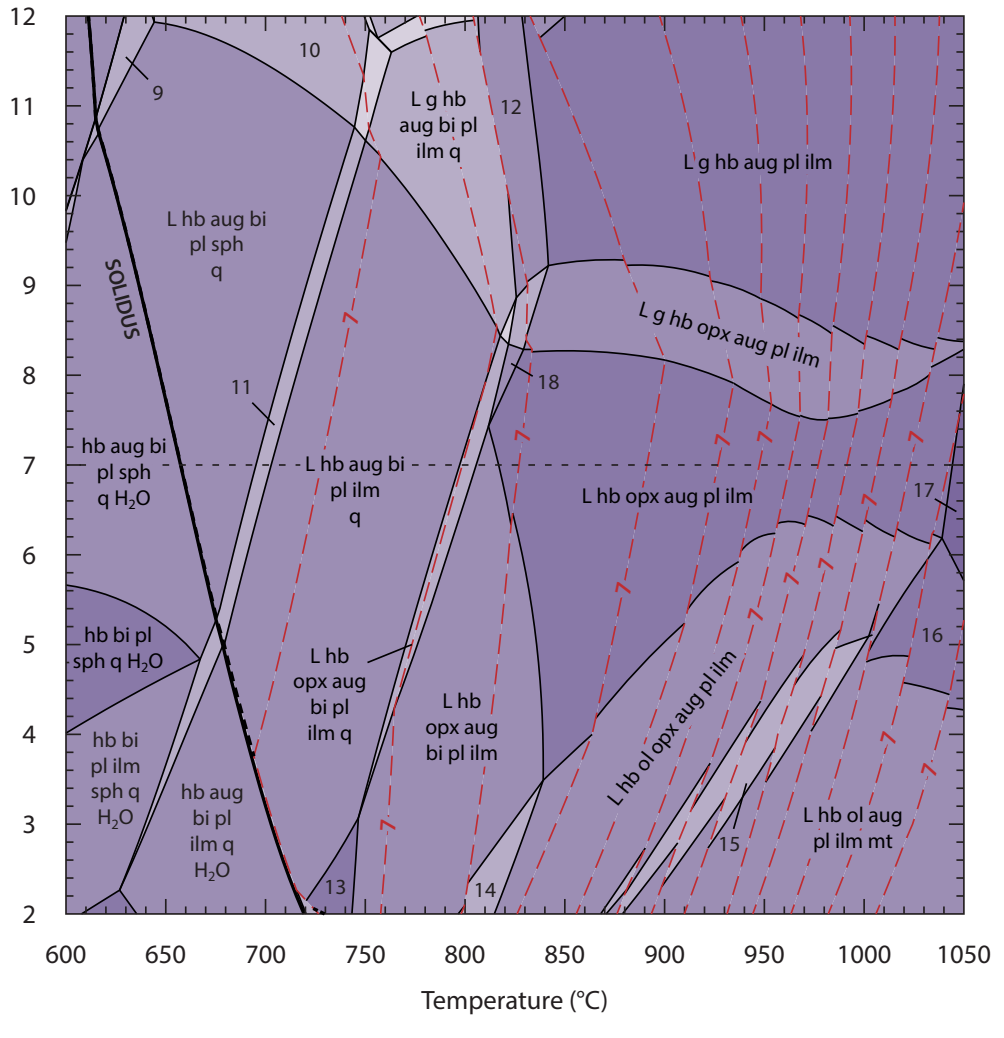

(d)

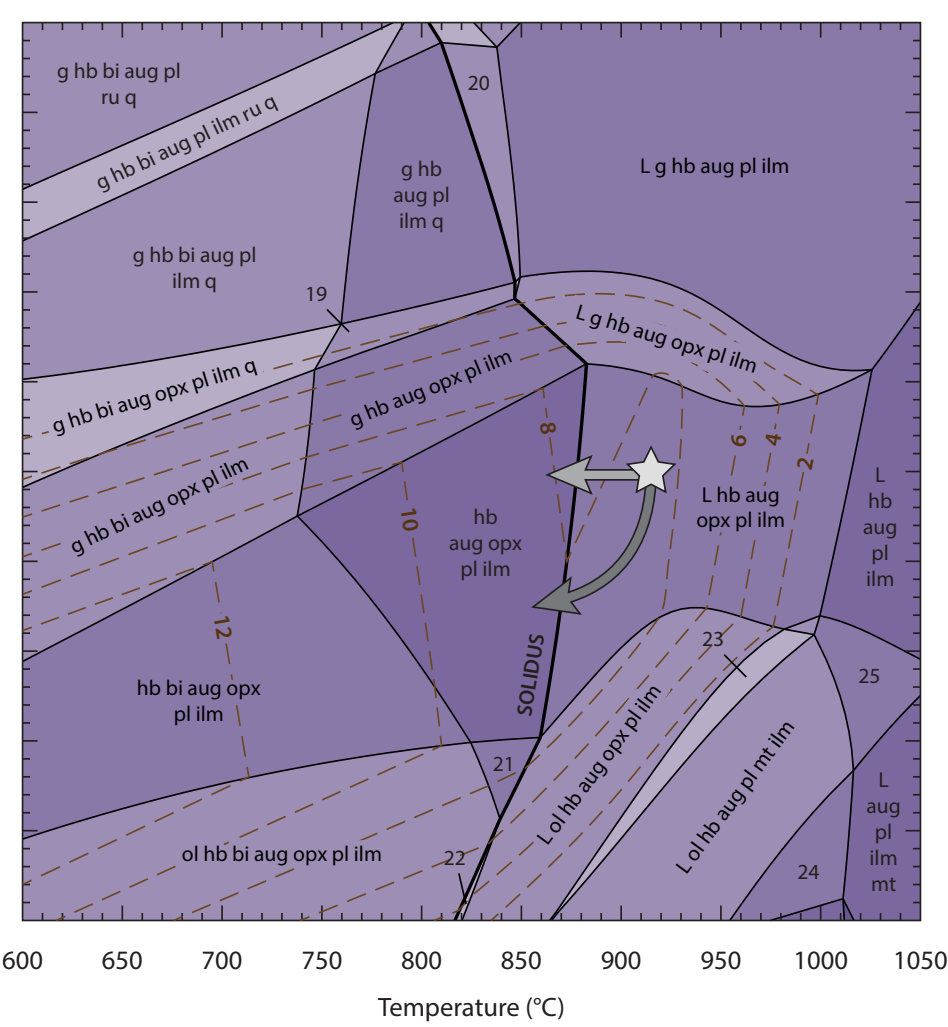

1 - L hb aug bi ep pl sph q 2 - $L \mathrm{~g}$ hb aug bi pl sph q 3 - L hb aug bi pl sph ilm q 4 - L hb opx aug bi pl ilm q 5 - $\mathrm{L} \mathrm{hb}$ aug bi pl ilm $\mathrm{H}_{2} \mathrm{O}$ 6 - L hb ol opx aug pl ilm mt $7-\mathrm{L} \mathrm{hb}$ aug $\mathrm{pl}$ ilm $\mathrm{q}$

8 - L hb opx aug pl ilm q

9- $L$ hb aug pl bi sph ep q $10-\mathrm{Lg} \mathrm{hb}$ aug pl bi sph q 11 - L hb aug pl bi sph ilm q 12 - $\mathrm{Lg}$ hb aug pl ilm q 13 - L hb aug bi pl ilm 14 - L hb ol opx aug bi pl ilm 15 - L hb ol opx aug pl ilm mt 16 - L hb ol aug pl ilm 17 - L hb aug pl ilm

$18-\mathrm{L}$ hb opx aug pl ilm q

19 - g hb aug opx pl ilm q 20 - L g hb aug pl ilm q 21 - ol hb aug opx pl ilm 22 - L ol hb bi aug opx pl ilm 23 - L ol hb aug opx pl ilm mt 24 - L ol aug pl ilm mt 25 - L hb aug pl ilm mt

\section{jmg_12212_f10.eps}




\section{University Library}

\section{- M M N E R VA A gateway to Melbourne's research publications}

Minerva Access is the Institutional Repository of The University of Melbourne

Author/s:

Palin, RM;White, RW;Green, ECR;Diener, JFA;Powell, R;Holland, TJB

Title:

High-grade metamorphism and partial melting of basic and intermediate rocks

Date:

2016-12-01

Citation:

Palin, R. M., White, R. W., Green, E. C. R., Diener, J. F. A., Powell, R. \& Holland, T. J. B. (2016). High-grade metamorphism and partial melting of basic and intermediate rocks. JOURNAL OF METAMORPHIC GEOLOGY, 34 (9), pp.871-892. https://doi.org/10.1111/ jmg.12212.

Persistent Link:

http://hdl.handle.net/11343/291611 